\title{
IMPACT OF VIRAL EPIDEMIC OUTBREAKS ON MENTAL HEALTH OF HEALTHCARE WORKERS: A RAPID SYSTEMATIC REVIEW
}

Ignacio Ricci-Cabello ${ }^{1,2,3^{*}}$ (0000-0002-4725-8274), Jose F. Meneses-Echavez ${ }^{4,5}$ (0000-00034312-6909), Maria Jesús Serrano-Ripoll ${ }^{1,2,6}$ (0000-0002-1869-1132), David Fraile-Navarro ${ }^{7}$ (0000-0002-1108-7071), Maria Antònia Fiol de Roque ${ }^{1,2}$ (0000-0001-8566-0929), Guadalupe Pastor Moreno ${ }^{3,8,9}$ (0000-0002-8039-3427), Adoración Castro ${ }^{1,10}$ (0000-0002-8025-4945), Isabel Ruiz-Pérez ${ }^{3,8,9}$ (0000-0002-9565-0502), Rocío Zamanillo Campos ${ }^{1,2,11}$ (0000-0001-7162-0889), Daniela Gonçalves-Bradley ${ }^{12}$ (0000-0002-5186-3792)

1. Health Research Institute of the Balearic Islands (IdISBa), Palma, Illes Balears, Spain. Carretera de Valldemossa, 79 Hospital Universitario Son Espases. Edificio S. 07120 Palma de Mallorca. Illes Balears. España.

2. Balearic Islands Health Services, Primary Care Research Unit of Mallorca, Palma, Illes Balears, Spain

3. Centro de Investigación Biomédica en Red (CIBERESP). Avda. Monforte de Lemos, 3-5. Pabellón 11. 28029 Madrid, Spain.

4. Division for Health Services, Norwegian Institute of Public Health. Oslo, Norway

5. Facultad de Cultura Física, Deporte y Recreación. Universidad Santo Tomás. Bogotá, Colombia.

6. University of Balearic Islands (UIB), Department of Psychology, Carretera de Valldemossa, km 7.5. Edificio Científico-Técnico. 07122, Palma, Balearic Islands, Spain

7. Australian Institute of Health Innovation, Macquarie University, Sydney, Australia

8. Escuela Andaluza de Salud Pública. Campus Universitario de Cartuja. Cuesta del Observatorio, 4. 18080. Granada, Spain.

9. Instituto de Investigación Biosanitaria (Ibs. Granada). Avda. de Madrid, 15. 18012. Granada, Spain

10. Research Institute of Health Sciences (IUNICS), University of Balearic Islands, Palma, Illes Balears, Spain. Carretera de Valldemossa, km 7.5. Edificio Científico-Técnico. 07122 Palma de Mallorca. Illes Balears. España.

11. Valencian International University (VIU), Department of Health, 46002, Valencia, Comunitat Valenciana, Spain

12. Nuffield Department of Population Health, University of Oxford, UK

*Correspondence to: I Ricci-Cabello nacho.ricci.cabello@gmail.com (or @NachoRiccion Twitter; orcid 0000-0002-4725-8274) 
medRxiv preprint doi: https://doi.org/10.1101/2020.04.02.20048892; this version posted April 6, 2020. The copyright holder for this preprint (which was not certified by peer review) is the author/funder, who has granted medRxiv a license to display the preprint in perpetuity. It is made available under a CC-BY-ND 4.0 International license.

\section{Content:}

Word count: 3,511

Figure 1. PRISMA Flowchart

Table 1. Characteristics of the included studies

Online Appendix 1. Search strategies

Online Appendix 2. List of excluded studies after full-text evaluation

Online Appendix 3. Risk of bias assessment

Online Appendix 4. Summary of Findings table of studies examining the impact of healthcare provision during and after viral epidemics on healthcare workers' mental health

Online Appendix 5. Forest plots

Online Appendix 6. Summary of Findings table of studies of interventions to reduce impact of infectious outbreaks on mental health of healthcare professionals

Online Appendix 7. Evidence profiles of the certainty of evidence concerning interventions for preventing the psychological impact of infectious epidemic outbreaks in healthcare workers

Online Appendix 8. PRISMA checklist 
medRxiv preprint doi: https://doi.org/10.1101/2020.04.02.20048892; this version posted April 6, 2020. The copyright holder for this preprint

\section{ABSTRACT}

Objectives: To examine the impact of providing healthcare during or after health emergencies caused by viral epidemic outbreaks on healthcare workers'(HCWs) mental health, and to assess the available evidence base regarding interventions to reduce such impact.

Design: Systematic rapid review and meta-analysis.

Data sources: MEDLINE, Embase, and PsycINFO, searched up to 23 March 2020.

Method: We selected observational and experimental studies examining the impact on mental health of epidemic outbreaks on HCWs. One reviewer screened titles and abstracts, and two reviewers independently reviewed full texts. We extracted study characteristics, symptoms, prevalence of mental health problems, risk factors, mental health interventions, and its impact. We assessed risk of bias for each individual study and used GRADE to ascertain the certainty of the evidence. We conducted a narrative and tabulated synthesis of the results. We pooled data using random-effects meta-analyses to estimate the prevalence of specific mental health problems.

Results: We included 61 studies (56 examining impact on mental health and five about interventions to reduce such impact). Most were conducted in Asia (59\%), in the hospital setting (79\%), and examined the impact of the SARS epidemic (69\%). The pooled prevalence was higher for anxiety (45\%, 95\% Cl 21 to $69 \%$; 6 studies, 3,373 participants), followed by depression (38\%, 95\% Cl 15 to 60\%; 7 studies, 3,636 participants), acute stress disorder (31\%, 95\% Cl 0 to 82\%, 3 studies , 2,587 participants), burnout (29\%, 95\% Cl 25 to 32\%; 3 studies; 1,168 participants), and post-traumatic stress disorder (19\%, 95\% Cl 11 to $26 \%, 10$ studies, 3,121 participants). Based on 37 studies, we identified factors associated with the likelihood of developing those problems, including sociodemographic (younger age and female gender), social (lack of social support, social rejection or isolation, stigmatization), and occupational (working in a high risk environment (frontline staff), specific occupational roles (e.g., nurse), and lower levels of specialised training, preparedness and job experience) factors. Five studies reported interventions for frontline $\mathrm{HCW}$, two of which were educational and aimed to prevent mental health problems by increasing HCWs' resilience. These interventions increased confidence in support and training, pandemic self-efficacy, and interpersonal problems solving (very low certainty). One multifaceted intervention implemented training and organisational changes) targeted at hospital nurses during the SARS epidemic, reporting improvements in 
medRxiv preprint doi: https://doi.org/10.1101/2020.04.02.20048892; this version posted April 6, 2020. The copyright holder for this preprint (which was not certified by peer review) is the author/funder, who has granted medRxiv a license to display the preprint in perpetuity. It is made available under a CC-BY-ND 4.0 International license.

anxiety, depression, and sleep quality (very low certainty). The two remaining interventions, which were multifaceted and based on psychotherapy provision, did not assess their impact.

Conclusion: The prevalence of anxiety, depression, acute and post-traumatic stress disorder, and burnout, was high both during and after the outbreaks. These problems not only have a long-lasting effect on the mental health of HCWs, but also hinder the urgent response to the current COVID-19 pandemic, by jeopardising attention and decision-making. Governments and healthcare authorities should take urgent actions to protect the mental health of HCWs. In light of the limited evidence regarding the impact of interventions to tackle mental health problems in HCWs, the risk factors identified in this study, more so when they are modifiable, represent important targets for future interventions. 


\section{SUMARY BOX}

\section{1: What is already known on this topic?}

- Previous studies showed that healthcare workers involved providing frontline care during viral epidemic outbreaks are at high risk of developing mental health problems.

- Given the current COVID-19 pandemic, there is an urgent need to synthesize the evidence regarding the impact of viral epidemic outbreaks on mental health of healthcare workers.

\section{2: What does this study add?}

- This timely systematic rapid review offers for the first time pooled estimations of the prevalence of the most common mental health problems experienced by HCWs during and after viral epidemic outbreaks, namely anxiety (45\%), depression $(38 \%)$, and acute stress disorder (31\%), among others.

- Our study also identifies a broad number of factors associated with these conditions, including sociodemographic factors such as younger age and female gender, social factors such as lack of social support, social rejection or isolation, stigmatization, and occupational factors such as working in a high risk environment, specific occupational roles, and having lower levels of specialised training, preparedness and job experience.

- Our study shows that, although educational and multifaceted interventions might mitigate the development of mental health problems, the certainty on the evidence is very low - therefore indicating that further high quality research is urgently needed to inform evidence-based policies for viral pandemics. 
medRxiv preprint doi: https://doi.org/10.1101/2020.04.02.20048892; this version posted April 6, 2020. The copyright holder for this preprint

\section{INTRODUCTION}

Infectious disease outbreaks are relatively common, ${ }^{1}$ often prompting an international response involving thousands of healthcare workers (HCWs). ${ }^{2}$ Providing frontline healthcare during infectious outbreaks increases the risk of HCWs developing mental health problems, both short and long-term. ${ }^{3}$ It has been suggested that specific occupational factors are associated with psychological outcomes of HCWs during an infectious disease outbreak. ${ }^{2}$ Working in a high-risk environment, adhering to quarantine, job-related stress, and belonging to a specific cadre were all considered to aggravate psychological outcomes. Perceived safety, namely through access to protective equipment, and specialised training, mitigated those outcomes. $^{2}$

During December 2019 a new infectious disease outbreak was reported in Wuhan, Hubei province, China, ${ }^{4}$ which was named COVID-19. ${ }^{5}$ The World Health Organization (WHO) declared COVID-19 a pandemic by March 11th 2020, and by 30 March 2020 it had spread to most countries and territories, with more than 693,000 known cases and a death toll of over 33,000 people. ${ }^{6}$ Early anecdotal evidence from Wuhan showed how this unprecedented situation impacted the mental health of frontline HCWs, who reported mental problems such as anxiety, depressive symptoms, anger, and fear. ${ }^{7}$ These problems cannot only have a long-lasting effect on the mental health of $\mathrm{HCWs},{ }^{3}$ but also hinder the urgent response to COVID-19, by jeopardising attention and decision-making. ${ }^{7}$ Tackling the mental health of HCWs during this pandemic is essential, and will strengthen healthcare systems' capacity. ${ }^{8}$

Previous systematic reviews have explored social and occupational factors associated with psychological outcomes in HCW during an infectious disease outbreak, ${ }^{2}$ and their perceptions of risk and use of coping strategies towards emerging respiratory infectious diseases. ${ }^{9}$ However, to date, the impact of viral disease outbreaks on specific mental health problems and the effectiveness of interventions to ameliorate such impact have not been systematically reported.

The aim of this rapid systematic literature review is twofold: i) to examine the impact of health emergencies caused by a viral pandemic or epidemic on HCWs mental health; and ii) to assess the effectiveness of interventions to reduce such impact. 
medRxiv preprint doi: https://doi.org/10.1101/2020.04.02.20048892; this version posted April 6, 2020. The copyright holder for this preprint (which was not certified by peer review) is the author/funder, who has granted medRxiv a license to display the preprint in perpetuity.

It is made available under a CC-BY-ND 4.0 International license .

\section{METHODS}

We conducted a rapid systematic review following WHO guidelines ${ }^{10}$ and Cochrane's recommendations for Rapid Reviews in response to COVID-19. ${ }^{11}$ We followed the Preferred Reporting Items for Systematic Reviews and Meta-Analyses (PRISMA) guidelines for planning, conducting and reporting this study. ${ }^{12}$

\section{Data Sources and Searches}

We designed specific search strategies for biomedical databases (MEDLINE/Ovid, EMBASE/Elsevier, and Psyclnfo/EBSCO), combining MeSH terms and free-text keywords (Online Appendix 1). We searched databases from inception to 23rd March 2020, and checked the list of included studies of relevant systematic reviews. ${ }^{913}{ }^{14}$ We used EndNote X $8^{\mathrm{TM}}$ to create a bibliographical database, and Rayyan to screen relevant records. ${ }^{15}$

\section{Selection criteria}

We included empirical studies examining the impact on mental health of epidemic outbreaks on HCWs, and studies about interventions to reduce such impact. We included observational (cross-sectional, case-control, and cohort studies), and experimental studies (non-controlled before-after studies, controlled before-after studies, non-randomised controlled trials, and randomised controlled trials).

We included studies on any type of health emergency caused by a viral epidemic or pandemic, and examining its impact on HCWs mental health during or after the crisis. For intervention studies, we included also those that examined interventions to protect mental health of healthcare workers prior, during or after the outbreak onset. All types of settings and healthcare professionals were accepted for inclusion. We included studies measuring any type of mental health problem or psychiatric morbidity. We excluded narrative reviews, thesis, editorials, protocols, letters to the editor, and studies published in languages other than English, Spanish or Portuguese.

\section{Study Selection}

One reviewer (of IRC, MJSR, MAFR, RZC, DGB) screened the retrieved references at title and abstract against the selection criteria. Two reviewers (of those aforementioned) independently and blinded against the others' judgements assessed full-text eligibility. We solved disagreements by consensus or by involving a third reviewer, if needed. 
medRxiv preprint doi: https://doi.org/10.1101/2020.04.02.20048892; this version posted April 6, 2020. The copyright holder for this preprint

(which was not certified by peer review) is the author/funder, who has granted medRxiv a license to display the preprint in perpetuity.

It is made available under a CC-BY-ND 4.0 International license .

\section{Data Extraction and Quality Assessment}

We used structured forms to extract relevant data, such as country, health emergency, setting, population, epidemiological design, number of participants, mental health conditions, clinical outcomes and their measurement tools, and main study results. For observational studies addressing the impact of health emergencies on HCWs mental health, we extracted the prevalence rate of the mental conditions examined in terms of the number of professionals suffering the condition (numerator) out of the total number of study participants (denominator). If available, we extracted information about the risk factors. For intervention studies (i.e., randomised and non-randomised trials), we extracted data about the characteristics of the intervention as well as that reported also for observational studies. We assessed the risk of bias of observational studies (i.e., cross-sectional, case-control, and cohort studies) by using the set of tools developed by Evidence Partners (McMaster University) ${ }^{16}$; whereas ROBINS I ${ }^{17}$ was applied to uncontrolled trials, and AMSTAR ${ }^{18}$ for systematic reviews.

One reviewer (of MJSR, MAFR, AC, DF, JM, GP, RZ) extracted all the data and assessed the risk of bias, while a second reviewer cross-checked the information for accuracy and completeness.

\section{Data Synthesis and Analysis}

We conducted a narrative and tabulated synthesis of the results, classifying the studies according to the type of study (i.e., impact of infectious disease outbreaks on HCWs mental health, or interventions to reduce such impact), and timing (i.e., before, during, or after the outbreak). We adapted a taxonomy proposed in a previous study ${ }^{14}$ to classify risk factors as social, occupational and sociodemographic.

For studies about the impact of outbreaks on mental health, we conducted random-effects meta-analyses to estimate the prevalence and $95 \%$ confidence interval $(\mathrm{Cl})$ of each type of mental health condition, using the STATA command "metaprop". We conducted subgroup analyses to explore potential differences in the prevalence of mental health disorders during vs. after the outbreak. Heterogeneity was quantified by the $I^{2}$ statistic, where $I^{2}>50 \%$ was deemed as substantial heterogeneity. ${ }^{19}$ Publication bias was examined with funnel plots and presence of asymmetry tested with Begg $^{20}$ and Egger tests. ${ }^{21}$ We used Stata, version 12.0 to conduct meta-analyses. 
medRxiv preprint doi: https://doi.org/10.1101/2020.04.02.20048892; this version posted April 6, 2020. The copyright holder for this preprint (which was not certified by peer review) is the author/funder, who has granted medRxiv a license to display the preprint in perpetuity. It is made available under a CC-BY-ND 4.0 International license .

\section{GRADE and 'Summary of findings' tables}

We used the GRADE approach ${ }^{22}$ to assess the quality of evidence related to the outcomes included in this rapid review. We used GRADEpro $2011{ }^{23}$ software to create 'Summary of findings' tables. For assessments of the overall quality of evidence for each outcome that included pooled data, we downgraded the evidence from 'high quality' by one level for serious, or by two levels for very serious, study limitations (risk of bias), indirectness of evidence, inconsistency, imprecision of effect estimates, or potential publication bias. ${ }^{22}$

\section{Patient and public involvement}

We have invited HCW frontline to promote the dissemination of these results, alongside members of the author team who are also frontline HCWs. 
medRxiv preprint doi: https://doi.org/10.1101/2020.04.02.20048892; this version posted April 6, 2020. The copyright holder for this preprint (which was not certified by peer review) is the author/funder, who has granted medRxiv a license to display the preprint in perpetuity. It is made available under a CC-BY-ND 4.0 International license .

\section{RESULTS}

\section{Search results}

The search resulted in a total of 2,317 records. After 143 duplicates were removed, 2,174 records remained to be screened. We excluded 2,042 records based on title and abstract screening. We assessed full-text 132 articles in full-text, of which we excluded 74. After including three additional studies identified from manual searches, sixty-one published studies met the inclusion criteria for this systematic rapid review. ${ }^{1324-83}$ Figure 1 illustrates the selection process of the included studies. Online Appendix 2 presents the excluded studies.

\section{Figure 1. PRISMA flow diagram}

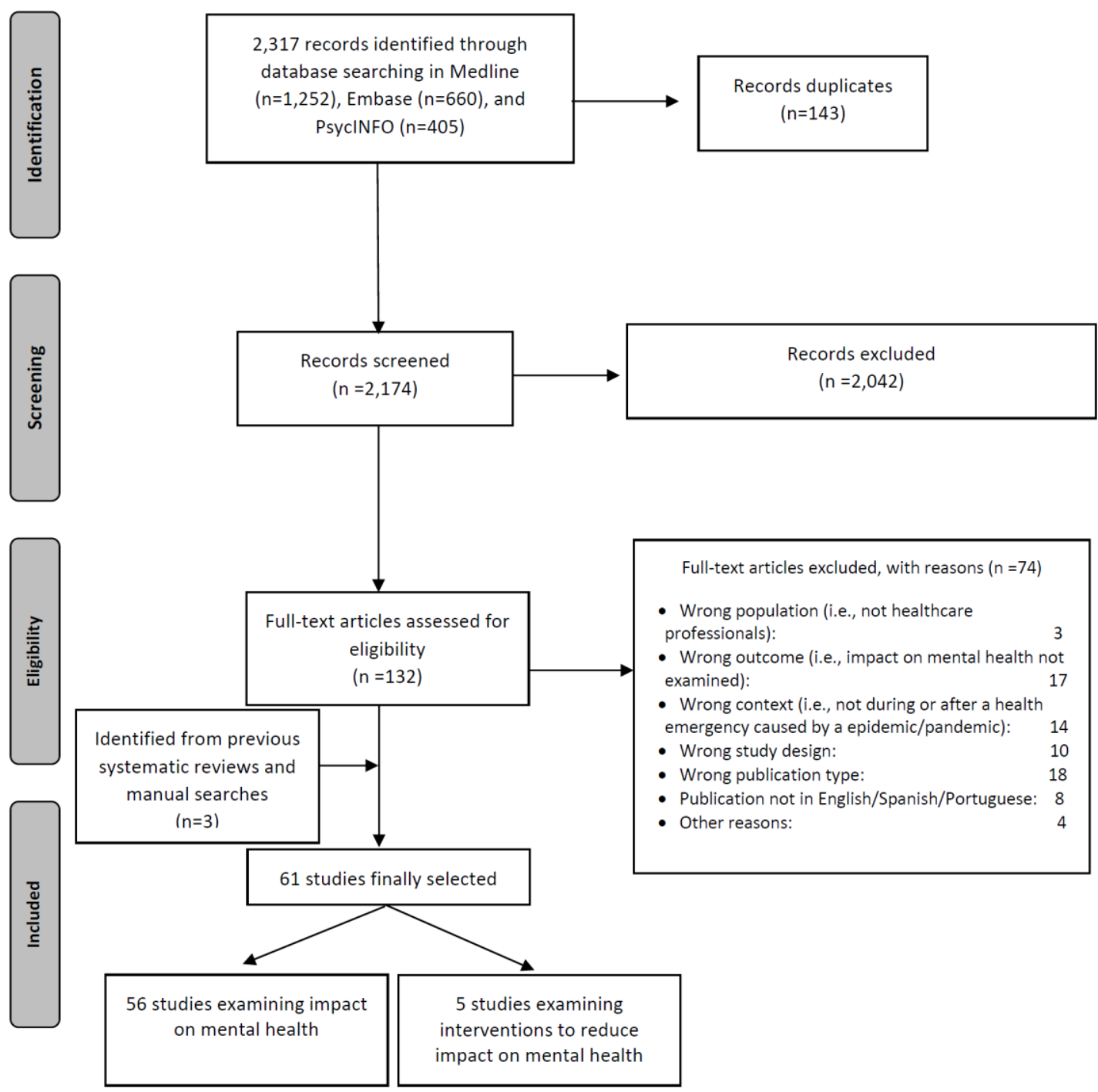


medRxiv preprint doi: https://doi.org/10.1101/2020.04.02.20048892; this version posted April 6, 2020. The copyright holder for this preprint (which was not certified by peer review) is the author/funder, who has granted medRxiv a license to display the preprint in perpetuity.

It is made available under a CC-BY-ND 4.0 International license .

\section{Characteristics of the studies}

This systematic rapid review included 38,415 participants (total). Most of the studies (59\%) were conducted in Asian countries, including China (30\%), South Korea (18\%), Taiwan (15\%) or Singapore (12\%). The mean number of participants was 612 (range 26 to 10,511). More than two-thirds (69\%) examined the impact of Severe acute respiratory syndrome (SARS epidemic), followed by Middle East respiratory syndrome coronavirus (MERS-CoV) (11\%). Three studies examined the impact of COVID-19. ${ }^{465383}$ Most studies were conducted during or after the infectious outbreak (92\%). Around three quarters took place in the hospital setting. General HCWs was the most common group (70\%), followed by nurses (20\%) and physicians (10\%). Post-traumatic stress disorder (PTSD) (38\%), anxiety (36\%), depression (28\%) and stress/distress symptoms (28\%) were the mental health conditions most frequently examined. The majority followed a cross-sectional design (82\%). The characteristics of the included studies are summarised in Table 1.

\section{Risk of bias assessment}

In general, main risks of bias in the 50 cross-sectional studies were the lack of use of reliable and valid instruments to measure mental health outcomes (high risk of bias in $22 \%$ of the studies) and selection bias (12\%). The main sources of bias across the seven cohort studies were selection bias (43\%) and inadequate follow-up of the cohorts (29\%). Main sources of bias of the two uncontrolled before-after studies were bias in selection of participants, and bias in outcome measurement. The case-control and the systematic review identified did not present serious risks of bias. Results of the risk of bias assessment are provided in Online Appendix 3. 
medRxiv preprint doi: https://doi.org/10.1101/2020.04.02.20048892; this version posted April 6, 2020. The copyright holder for this preprint (which was not certified by peer review) is the author/funder, who has granted medRxiv a license to display the preprint in perpetuity.

It is made available under a CC-BY-ND 4.0 International license.

Table 1. Features of the studies selected $(\mathrm{N}=61)$

\begin{tabular}{|c|c|c|}
\hline & $\mathrm{N}$ & $\%$ \\
\hline \multicolumn{3}{|l|}{ Year of the study publication } \\
\hline \begin{tabular}{l|l|}
$2001-2005$ \\
\end{tabular} & 22 & 36 \\
\hline $2006-2010$ & 19 & 31 \\
\hline $2011-2015$ & 5 & 8 \\
\hline $2016-2020$ & 15 & 25 \\
\hline \multicolumn{3}{|l|}{ Epidemiologic design } \\
\hline \begin{tabular}{l|l} 
& Cross-sectional \\
\end{tabular} & 50 & 82 \\
\hline Cohort study & 7 & 11 \\
\hline Quasi-experimental & 2 & 3 \\
\hline Case-control & 1 & 2 \\
\hline \begin{tabular}{l|l} 
& Systematic literature reviews \\
\end{tabular} & 1 & 2 \\
\hline Number of participants $*$ & 612 & $(26-10,511)$ \\
\hline \multicolumn{3}{|l|}{ Mental health problems $\downarrow$} \\
\hline \begin{tabular}{l|l} 
& Post-traumatic stress disorder \\
\end{tabular} & 23 & 38 \\
\hline Anxiety & 22 & 36 \\
\hline Depression & 17 & 28 \\
\hline Stress/distress & 17 & 28 \\
\hline Burnout & 8 & 13 \\
\hline Acute stress disorder & 7 & 11 \\
\hline Mental health status (overall assessment) & 20 & 33 \\
\hline Others & 15 & 25 \\
\hline \multicolumn{3}{|l|}{ Country $\downarrow$} \\
\hline \begin{tabular}{l|l} 
China \\
\end{tabular} & 18 & 30 \\
\hline Canada & 12 & 20 \\
\hline South Korea & 11 & 18 \\
\hline Taiwan & 9 & 15 \\
\hline Singapore & 7 & 12 \\
\hline Saudi Arabia & 3 & 5 \\
\hline \begin{tabular}{l|l|} 
& Others \\
\end{tabular} & 11 & 18 \\
\hline \multicolumn{3}{|l|}{ Study timing } \\
\hline \begin{tabular}{l|l} 
& After outbreak \\
\end{tabular} & 28 & 46 \\
\hline During outbreak & 28 & 46 \\
\hline Both during and after outbreak & 2 & 3 \\
\hline Prior, during and after outbreak & 2 & 3 \\
\hline \begin{tabular}{|l|l} 
& Prior outbreak onset \\
\end{tabular} & 1 & 2 \\
\hline \multicolumn{3}{|l|}{ Type of health emergency } \\
\hline \begin{tabular}{l|l} 
& SARS \\
\end{tabular} & 42 & 69 \\
\hline MERS-COV & 7 & 11 \\
\hline H1N1 influenza virus & 4 & 7 \\
\hline Ebola & 4 & 7 \\
\hline COVID-19 & 3 & 5 \\
\hline \begin{tabular}{l|l} 
& H7N9 influenza virus \\
\end{tabular} & 1 & 2 \\
\hline \multicolumn{3}{|l|}{ Population } \\
\hline \begin{tabular}{l|l|} 
& Health care workers in general \\
\end{tabular} & 43 & 70 \\
\hline Nurses & 12 & 20 \\
\hline Doctors & 6 & 10 \\
\hline \multicolumn{3}{|l|}{ Setting } \\
\hline \begin{tabular}{l|l} 
& Hospital \\
\end{tabular} & 48 & 79 \\
\hline Healthcare facilities in general & 8 & 13 \\
\hline Primary Care centre & 3 & 5 \\
\hline Non specified & 2 & 3 \\
\hline
\end{tabular}

* mean and range, + percentages exceeding $100 \%$ as categories are not mutually exclusive. 
medRxiv preprint doi: https://doi.org/10.1101/2020.04.02.20048892; this version posted April 6, 2020. The copyright holder for this preprint

(which was not certified by peer review) is the author/funder, who has granted medRxiv a license to display the preprint in perpetuity.

It is made available under a CC-BY-ND 4.0 International license .

\section{Prevalence of mental health problems in HCWs during and after infectious disease outbreaks}

Fifty-six studies examined the mental health problems among frontline HCWs during and/or after an infectious disease outbreak (Online Appendix 4). The great majority of them reported clinically significant mental health symptoms, most frequently PTSD, anxiety, depression, and burnout. For clinically significant symptoms of mental health disorders, the pooled prevalence was higher for anxiety (45\%, 95\% Cl 21 to 69\%, I2 99.7\%; 6 studies, 3,373 participants), followed by depression (38\%, 95\% Cl 15 to $60 \%, 12$ 99.6\%; 7 studies , 3,636 participants), and PTSD (19\%, 95\% Cl 11 to 26\%, I2 97.6\%; 10 studies, 3,121 participants). Three studies reported the prevalence of burnout ( $29 \%, 95 \% \mathrm{Cl} 25$ to $32 \%$; 1,168 participants), and three reported the prevalence of acute stress disorder (31\%, $95 \% \mathrm{Cl} 0$ to $82 \%, 2,587$ participants). Subgroup analyses found little or no differences in prevalence during vs. after the outbreaks (Online Appendix 5). Begg's and Egger's tests suggested the absence of publication bias for all the meta-analyses conducted.

\section{Risk factors for mental health problems in HCWs during and after infectious disease outbreaks}

Thirty-seven studies examined a large number of occupational, sociodemographic and social factors associated with the likelihood of developing mental health problems while providing frontline healthcare during an infectious disease outbreak (Online Appendix 4).

The main occupational factors were working in a high risk environment, higher perception of threat and risk, specialised training received, and specific occupational role. Working in a high risk environment was associated with different mental health problems, namely depression, ${ }^{46}$ anxiety, ${ }^{46} 526077$ PTSD, ${ }^{28} 72758182$ and burnout. ${ }^{76}$ The definition of high risk environment varied across studies, but usually included being in direct contact with infected patients, either providing care, ${ }^{2877}$ or being responsible for cleaning and disinfection. ${ }^{52}$

Likewise, higher perception of threat and risk was also associated with a higher prevalence of a number of different mental health problems, including depression, ${ }^{55}$ anxiety, ${ }^{25}$ and PTSD. ${ }^{637281}$ Lack of specialised training was a risk factor for anxiety, ${ }^{6079}$ PTSD, ${ }^{75}$ and burnout. ${ }^{63}$

Some of the studies that recruited more than one cadre reported that specific HCWs were at higher risk of developing mental health problems. One study each found that nurses were more likely to develop PTSD ${ }^{75}$ and burnout, ${ }^{76}$ whereas one study ${ }^{26}$ reported that resident pulmonologists were at higher risk of burnout. 
medRxiv preprint doi: https://doi.org/10.1101/2020.04.02.20048892; this version posted April 6, 2020. The copyright holder for this preprint

(which was not certified by peer review) is the author/funder, who has granted medRxiv a license to display the preprint in perpetuity.

It is made available under a CC-BY-ND 4.0 International license .

Other occupational risk factors for PTSD were job stress, ${ }^{63}$ and less job experience, ${ }^{75}$ whereas lower levels of organisational support increased the risk of burnout. ${ }^{59}$

Studies addressing sociodemographic and social risk factors focused on PTSD and burnout. Younger age was a risk factor for both PTSD ${ }^{75}$ and burnout, ${ }^{26}$ while female gender was associated with higher levels of PTSD in HCWs. ${ }^{75}$ Feelings of social rejection or isolation, ${ }^{63}$ and higher impact of the outbreak on daily life ${ }^{72}$ increased the likelihood of developing PTSD, whereas lack of family and friends support were associated with burnout. ${ }^{43}$ In addition, stigmatisation, ${ }^{44}$ social rejection, ${ }^{67}$ and lower levels of social support were identified as risk factors for stress. ${ }^{83}$

\section{Interventions to reduce the mental health impact of viral outbreaks in HCWs}

Five studies 2433406270 described five different interventions to reduce the mental health impact of viral outbreaks in HCWs (Online Appendix). Two studies implemented in Canada evaluated two educational interventions for improving HCWs mental health by increasing resilience. ${ }^{2462}$ Aiello and colleagues ${ }^{24}$ described an educational intervention targeted to HCWs during the SARS epidemic, which consisted of a face-to-face group training session based on Folkman and Greer's model of coping. ${ }^{84}$ The session focused on stressors associated with pandemic influenza and on organisational and individual approaches to building resilience and reducing stress. While most participants did not feel prepared to deal confidently with the pandemic before the session (35\%), there was a higher proportion of participants who felt better able to cope after the session (76\%).

Maunder and colleagues explored the impact of a computer-assisted resilience training to prepare HCWs for a potential pandemic influenza. ${ }^{62}$ The course consisted of modules incorporating different modalities of learning (knowledge-based modules, relaxation skills, and self-assessment modules using questionnaires to characterize interpersonal problem and coping style). The intervention improved confidence in support and training, pandemic selfefficacy and interpersonal problems $(p<0.05)$. We have very low confidence on the evidence of educational interventions for preventing the psychological impact of infectious epidemic outbreaks in HCWs (detailed in Online Appendix 7) due to the study design (uncontrolled before-after studies) and very serious risk of bias with regard to confounding and measurement of outcomes. 
medRxiv preprint doi: https://doi.org/10.1101/2020.04.02.20048892; this version posted April 6, 2020. The copyright holder for this preprint (which was not certified by peer review) is the author/funder, who has granted medRxiv a license to display the preprint in perpetuity. It is made available under a CC-BY-ND 4.0 International license.

Two studies examined two multifaceted interventions combining training and implementation of organizational changes. ${ }^{3370} \mathrm{~A}$ study in Taiwan ${ }^{33}$ evaluated the effects of a multifaceted intervention to prevent depression and anxiety in hospital nurses during the SARS epidemic. The intervention included in-service training, manpower allocation, gathering sufficient protective equipment, and establishment of a mental health team. The authors observed statistically significant improvements in nurses' anxiety and depression along with sleep quality at two weeks follow-up. Another study described a multifaceted intervention to improve resilience and prevent PTSD in HCWs during the Ebola epidemic in the USA, Philippines, and West Africa. ${ }^{70}$ The intervention, based on the Anticipate, Plan and Deter Responder Risk and Resilience model, included pre-deployment development of an individualized resilience plan and an in-theatre, real-time self-triage system, to allow HCWs to assess and manage the full range of psychological risk and resilience for themselves and their families. The potential effectiveness of this intervention was not studied. Our confidence on the evidence for multifaceted interventions for preventing the psychological impact during infectious epidemic outbreaks in HCWs was very low (Online Appendix 7) due to limitations in the study design (uncontrolled before after studies) and very serious risk of bias (high risk of selection bias and high risk of bias in measurement of outcomes).

Finally, Khee et al. 2004 reported an intervention in 188 hospital nurses in Singapore, consisted in the provision of psychological support during the SARS outbreak. ${ }^{40}$ The intervention, not based on any specific psychotherapeutic model, comprised multiple sessions (75 minutes per session) and was aimed at preserving their mental health. The primary goal of therapy was to externalise all their emotions, and bring support to each other. The effectiveness of this intervention was not studied. 
medRxiv preprint doi: https://doi.org/10.1101/2020.04.02.20048892; this version posted April 6, 2020. The copyright holder for this preprint

\section{DISCUSSION}

\section{Summary of findings}

In this timely systematic rapid review we synthesized evidence from 61 studies examining the impact on mental health of providing frontline healthcare during infectious disease outbreaks. Results showed that HCWs commonly present high levels of anxiety, depression, PTSD, acute disorder and burnout, both during and after the outbreaks. We identified a broad number of risk factors for these conditions, including sociodemographic factors such as younger age and female gender, and social factors such as lack of social support, social rejection or isolation, stigmatization. Occupational factors entailed working in a high risk environment (frontline staff), specific occupational roles (e.g., nurse), and having lower levels of specialized training, preparedness and job experience. In contrast with the high number of studies examining impact on mental health, there is limited evidence regarding the impact of interventions to reduce mental health problems in this particularly vulnerable population, and overall its certainty is very low, mainly due to study design and serious risk of bias.

\section{Strengths and limitations of the review}

This is a timely and comprehensive rapid review of the current literature on the impact of infectious disease outbreaks on the mental health of HCWs. We examined three relevant areas, namely the prevalence of mental health problems, factors associated with an increased likelihood of developing those problems, and the effects of interventions to improve mental health of HCWs. We followed the highest methodological standards when undertaking the current rapid review, ${ }^{10}$ and we used the GRADE approach to evaluate the certainty of the evidence, in order to facilitate evidence-informed decision making processes. Our review team is also a strength, as it included experts in evidence synthesis, Cochrane authors, members of the GRADE Working Group, physicians, nurses, editors, psychologists, and psychiatrists. There were also some limitations underlying this work. Despite searching three major databases and manually searching references of previously published systematic reviews, we did not examine gray literature; hence, we cannot discard that relevant references may have been missed out. We observed high heterogeneity when pooling data, which could be partially attributed to the high variability across studies in terms of study population (e.g. occupational role), context (e.g. magnitude of the health emergency caused by epidemic) and outcome measures. In light of this, our results should be interpreted with caution. 
medRxiv preprint doi: https://doi.org/10.1101/2020.04.02.20048892; this version posted April 6, 2020. The copyright holder for this preprint

\section{Discussion of the main findings}

Some of the risk factors associated with mental health problems while providing frontline care during infectious disease outbreaks cannot be modified. In this way, working in a high risk environment increases the risk of developing clinically significant symptoms, namely depression, ${ }^{46}$ anxiety, ${ }^{46} 526077$ PTSD, ${ }^{2872} 758182$ and burnout. ${ }^{76}$ Likewise, it seems like specific cadres are more likely to report mental health problems, namely PTSD, ${ }^{75}$ and burnout. ${ }^{2676}$ However this review also identified specific modifiable factors that can be addressed in advance and mitigate the risk brought by the aforementioned factors. Lack of specialized training was associated with anxiety, ${ }^{6079}$ PTSD, ${ }^{75}$ and burnout, ${ }^{63}$ and higher perception of threat and risk was associated with depression, ${ }^{55}$ anxiety, ${ }^{25}$ and PTSD ${ }^{38} 637281$. Long-term institutional preparedness is possible for both factors, through the development and implementation of specialized training that includes infection prevention, diagnostics, patient care, staff, and communication. ${ }^{85}$

Continuous communication between HCWs and managers, including the provision of up-todate facts about the progression of the outbreak, can convey institutional support, ${ }^{59}$ and promote the acquisition of knowledge and confidence for those HCWs who have less job experience. ${ }^{75}$ Likewise, managers are essential to mitigate feelings of social isolation ${ }^{5063}$ and stigmatization, ${ }^{44}$ especially among those $\mathrm{HCW}$ s who have to be quarantined. ${ }^{13}$ The proliferation of online mobile-based technologies will play an essential role in promoting connectedness and decrease the feelings of isolation and stigmatization, ${ }^{86}$ and can also be used for informal contacts between HCWs who are quarantined.

Although limited, evidence from intervention studies indicates that educational interventions have the potential to increase knowledge and resilience, ${ }^{2462}$ even when implemented during an outbreak. ${ }^{33}$

\section{Limitations of available evidence and future research needs}

We identified 56 studies reporting on the impact on mental health of providing frontline healthcare during an infectious disease outbreak, however most of the studies did not use validated methods to assess mental health, which limits the generalizability of our findings. Furthermore, only a handful of studies assessed the efficacy of interventions to ameliorate the impact of health emergencies on mental health of HCWs. 
medRxiv preprint doi: https://doi.org/10.1101/2020.04.02.20048892; this version posted April 6, 2020. The copyright holder for this preprint

(which was not certified by peer review) is the author/funder, who has granted medRxiv a license to display the preprint in perpetuity.

It is made available under a CC-BY-ND 4.0 International license .

It is expected the proliferation of a large volume of studies examining the impact of COVID-19 on HCWs' mental health during the near future. To make progress in this area, future studies should address these limitations of the available literature. The use of validated measurement tools and more representative sample sizes are warranted in order to strengthen the quality of the evidence in this area. Intervention studies should also adhere to international reporting standards such as CONSORT ${ }^{85}$ and TIDieR. ${ }^{87}$

\section{Conclusions}

As we demonstrated in our review, the mental health burden for HCWs during pandemics is especially high both during and after the outbreak. Of note for its similarity to the current COVID-19 crisis, are the experiences gained from the previous SARS outbreak. This time, given the size, scale and importance of the current pandemic, these trends could be much worse.

We urge governments, policy makers and relevant stakeholders to monitor and follow these outcomes and conduct scientifically sound interventional research, in order to mitigate mental health impact on HCWs.

The physical health of HCWs is already at stake from the virus, and once we tackle the current pandemic, we will need to heal the healers, not only for the sake of having a prepared and resilient work-force, but as we owe them from the tremendous sacrifices they are doing. If we want to address these concerns and be able to mitigate its impact, we need to act soon. 
medRxiv preprint doi: https://doi.org/10.1101/2020.04.02.20048892; this version posted April 6, 2020. The copyright holder for this preprint (which was not certified by peer review) is the author/funder, who has granted medRxiv a license to display the preprint in perpetuity. It is made available under a CC-BY-ND 4.0 International license.

Contributors: IRC, IRP and MJSR had the idea for the study. IRC designed the search strategy. IRC, MJSR, MAFR, RZC, DGB screened abstracts and full texts. MJSR, MAFR, AC, DFN, JM, GP, RZ, DGB acquired data, and assessed risk of bias in studies. IRC did the data analysis. All authors interpreted the data analysis. IRC and DGB wrote the manuscript, with revisions from all authors. The corresponding author attests that all listed authors meet authorship criteria and that no others meeting the criteria have been omitted. IRC is the guarantor.

Funding: No specific funding for this study. IRC is a recipient of a Miguel Servet Fellowship (project number CP17/00017) funded by the Spanish Government. The funding sources had no role in the design and conduct of the study; collection, management, analysis, and interpretation of the data; preparation, review, or approval of the manuscript; and decision to submit the manuscript for publication.

Competing interests: All authors have completed the ICMJE uniform disclosure form at www.icmje.org/coi_disclosure.pdf and declare: no support from any organisation for the submitted work; no financial relationships with any organisations that might have an interest in the submitted work in the previous three years; no other relationships or activities that could appear to have influenced the submitted work.

Ethical approval: Not required

Data sharing: No additional data available.

Transparency: The lead author affirms that the manuscript is an honest, accurate, and transparent account of the study being reported; that no important aspects of the study have been omitted; and that any discrepancies from the study as planned (and, if relevant, registered) have been explained. 
medRxiv preprint doi: https://doi.org/10.1101/2020.04.02.20048892; this version posted April 6, 2020. The copyright holder for this preprint (which was not certified by peer review) is the author/funder, who has granted medRxiv a license to display the preprint in perpetuity. It is made available under a CC-BY-ND 4.0 International license .

\section{REFERENCES}

1. World Health Organization. How the 4 biggest outbreaks since the start of this century shattered some long-standing myths Accessed 26.03.2020 [Available from: www.who.int/csr/disease/ebola/ebola-6-months/myths/en/.]

2. Brooks SK, Dunn R, Amlôt R, et al. A systematic, thematic review of social and occupational factors associated with psychological outcomes in healthcare employees during an infectious disease outbreak. J Occup Environ Med;60(3):248-57. doi: 10.1097/JOM.0000000000001235

3. Maunder RG, Lancee WJ, Balderson KE, et al. Long-term psychological and occupational effects of providing hospital healthcare during SARS outbreak. Emerg Infect Dis 2006;12(12):1924-32.

4. Wang C, Horby PW, Hayde FG, et al. A novel coronavirus outbreak of global health concern. Lancet 2020;395(10223):470-3. doi: 10.1016/S0140-6736(20)30185-9

5. World Health Organization. Naming the coronavirus disease (COVID-19) and the virus that causes it 2020 [Available from: https://www.who.int/emergencies/diseases/novelcoronavirus-2019/technical-guidance/naming-the-coronavirus-disease-(covid-2019)and-the-virus-that-causes-it.]

6. World Health Organization. Coronavirus disease 2019 (COVID-19). Situation Report - 70. 2020. [Available from: https://www.who.int/docs/defaultsource/coronaviruse/situation-reports/20200330-sitrep-70-covid19.pdf?sfursn=7e0fe3f8 2]

7. Kang L, Li Y, Hu S, et al. The mental health of medical workers in Wuhan, China dealing with the 2019 novel coronavirus. The Lancet Psychiatry 2020;7:e14. doi: 10.1016/S22150366(20)30047-X

8. Bao Y, Sun Y, Meng S, et al. 2019-nCoV epidemic: address mental health care to empower society. The Lancet 2020;395(10224):PE37-E38. doi: 10.1016/S0140-6736(20)30309-3

9. Koh Y, Hegney DG, Drury V. Comprehensive systematic review of healthcare workers' perceptions of risk and use of coping strategies towards emerging respiratory infectious diseases. International journal of evidence-based healthcare 2011;9(4):40319. doi: 10.1111/j.1744-1609.2011.00242.x [published Online First: 2011/11/19]

10. Tricco AC, Langlois EV, Straus SE. Rapid reviews to strengthen health policy and systems: a practical guide: World Health Organization Geneva 2017.

11. Cochrane Rapid Reviews Methods Group. Cochrane Rapid Reviews - Interim Methods Guidance [Available from: https://www.cochrane.org/cochranes-work-rapid-reviewsresponse-covid-19.

12. Moher D, Liberati A, Tetzlaff J, et al. Preferred Reporting Items for Systematic Reviews and Meta-Analyses: The PRISMA Statement. PLOS Medicine 2009;6(7):e1000097. doi: 10.1371/journal.pmed.1000097

13. Brooks SK, Dunn R, Amlot R, et al. A Systematic, Thematic Review of Social and Occupational Factors Associated With Psychological Outcomes in Healthcare Employees During an Infectious Disease Outbreak. Journal of occupational and environmental medicine 2018;60(3):248-57.

14. Brooks SK, Dunn R, Amlot R, et al. A Systematic, Thematic Review of Social and Occupational Factors Associated With Psychological Outcomes in Healthcare Employees During an Infectious Disease Outbreak. Journal of occupational and environmental medicine 2018;60(3):248-57. doi: 10.1097/jom.0000000000001235 [published Online First: 2017/12/19] 
medRxiv preprint doi: https://doi.org/10.1101/2020.04.02.20048892; this version posted April 6, 2020. The copyright holder for this preprint (which was not certified by peer review) is the author/funder, who has granted medRxiv a license to display the preprint in perpetuity. It is made available under a CC-BY-ND 4.0 International license .

15. Ouzzani M, Hammady H, Fedorowicz Z, et al. Rayyan-a web and mobile app for systematic reviews. Systematic reviews 2016;5(1):210. doi: 10.1186/s13643-016-0384-4 [published Online First: 2016/12/07]

16. Partners E. Tool to Assess Risk of Bias. Contributed by the CLARITY Group at McMaster University.: McMaster University; [Available from: https://www.evidencepartners.com/resources/methodological-resources/.

17. Sterne JA, Hernán MA, Reeves BC, et al. ROBINS-I: a tool for assessing risk of bias in nonrandomised studies of interventions. BMJ (Clinical research ed) 2016;355:14919. doi: 10.1136/bmj.i4919

18. Shea BJ, Grimshaw JM, Wells GA, et al. Development of AMSTAR: a measurement tool to assess the methodological quality of systematic reviews. BMC Medical Research Methodology 2007;7(1):10. doi: 10.1186/1471-2288-7-10

19. Deeks JJ, Higgins JP, Altman DG, et al. Analysing data and undertaking meta-analyses. Cochrane handbook for systematic reviews of interventions 2019:241-84.

20. Begg CB, Mazumdar M. Operating characteristics of a rank correlation test for publication bias. Biometrics 1994:1088-101.

21. Egger M, Smith GD, Schneider M, et al. Bias in meta-analysis detected by a simple, graphical test. BMJ (Clinical research ed) 1997;315(7109):629-34.

22. Schünemann HJ, Vist GE, Higgins JP, et al. Interpreting results and drawing conclusions. Cochrane handbook for systematic reviews of interventions 2019:403-31.

23. GRADE Working Group. GRADEs profiler. Version 3.6.1. GRADE Working Group, 2011.

24. Aiello A, Khayeri MY-E, Raja S, et al. Resilience training for hospital workers in anticipation of an influenza pandemic. The Journal of continuing education in the health professions 2011;31(1):15-20.

25. Alsubaie S, Hani Temsah M, Al-Eyadhy AA, et al. Middle East Respiratory Syndrome Coronavirus epidemic impact on healthcare workers' risk perceptions, work and personal lives. Journal of infection in developing countries 2019;13(10):920-26.

26. Austria-Corrales F, Cruz-Valdes B, Herrera-Kiengelher L, et al. [Burnout syndrome among medical residents during the influenza A H1N1 sanitary contigency in Mexico]. Sindrome de burnout en medicos mexicanos en entrenamiento durante una contingencia sanitaria por virus de influenza A H1N1 2011;147(2):97-103.

27. Bai $Y$, Lin C-C, Lin C-Y, et al. Survey of stress reactions among health care workers involved with the SARS outbreak. Psychiatric services (Washington, DC) 2004;55(9):1055-7.

28. Bukhari EE, Temsah $\mathrm{MH}$, Aleyadhy AA, et al. Middle East respiratory syndrome coronavirus (MERS-COV) outbreak perceptions of risk and stress evaluation in nurses. Journal of infection in developing countries 2016;10(8):845-50.

29. Chan AOM, Huak CY. Psychological impact of the 2003 severe acute respiratory syndrome outbreak on health care workers in a medium size regional general hospital in Singapore. Occupational medicine (Oxford, England) 2004;54(3):190-6.

30. Chan SS, Leung GM, Tiwari AF, et al. The impact of work-related risk on nurses during the SARS outbreak in Hong Kong. Family \& community health 2005;28(3):274-87. doi: 10.1097/00003727-200507000-00008 [published Online First: 2005/06/17]

31. Chen C-S, Wu H-Y, Yang P, et al. Psychological Distress of Nurses in Taiwan Who Worked During the Outbreak of SARS. Psychiatric Services 2005;56(1):76-79.

32. Chen N-H, Wang P-C, Hsieh M-J, et al. Impact of severe acute respiratory syndrome care on the general health status of healthcare workers in taiwan. Infection control and hospital epidemiology 2007;28(1):75-9.

33. Chen R, Chou K-R, Huang Y-J, et al. Effects of a SARS prevention programme in Taiwan on nursing staff's anxiety, depression and sleep quality: a longitudinal survey. International journal of nursing studies 2006;43(2):215-25. 
medRxiv preprint doi: https://doi.org/10.1101/2020.04.02.20048892; this version posted April 6, 2020. The copyright holder for this preprint (which was not certified by peer review) is the author/funder, who has granted medRxiv a license to display the preprint in perpetuity. It is made available under a CC-BY-ND 4.0 International license .

34. Chong $\mathrm{M}-\mathrm{Y}$, Wang $\mathrm{W}-\mathrm{C}$, Hsieh $\mathrm{W}-\mathrm{C}$, et al. Psychological impact of severe acute respiratory syndrome on health workers in a tertiary hospital. The British journal of psychiatry : the journal of mental science 2004;185(342367):127-33.

35. Chua SE, Cheung V, Cheung C, et al. Psychological effects of the SARS outbreak in Hong Kong on high-risk health care workers. Canadian journal of psychiatry Revue canadienne de psychiatrie 2004;49(6):391-3.

36. Goulia P, Mantas C, Dimitroula D, et al. General hospital staff worries, perceived sufficiency of information and associated psychological distress during the A/H1N1 influenza pandemic. BMC infectious diseases 2010;10(100968551):322.

37. Grace SL, Hershenfield K, Robertson E, et al. The occupational and psychosocial impact of SARS on academic physicians in three affected hospitals. Psychosomatics 2005;46(5):385-91.

38. Ho SMY, Kwong-Lo RSY, Mak CWY, et al. Fear of severe acute respiratory syndrome (SARS) among health care workers. Journal of consulting and clinical psychology 2005;73(2):344-9.

39. Ji D, Ji Y-J, Duan X-Z, et al. Prevalence of psychological symptoms among Ebola survivors and healthcare workers during the 2014-2015 Ebola outbreak in Sierra Leone: a crosssectional study. Oncotarget 2017;8(8):12784-91.

40 Khee KS, Lee LB, Chai OT, Loong CK, et al. The psychological impact of SARS on health care providers. Crit Care Shock 2004;7(2):99-106.

41. Tham KY, Tan YH, Loh OH, Tan WL, et al. Psychological morbidity among emergency department doctors and nurses after the SARS outbreak. Hong Kong J Emerg Med 2005;12(4):215-23.

42. Khalid I, Khalid TJ, Qabajah MR, et al. Healthcare Workers Emotions, Perceived Stressors and Coping Strategies During a MERS-CoV Outbreak. Clinical medicine \& research 2016;14(1):7-14.

43. Kim JS, Choi JS. Factors Influencing Emergency Nurses' Burnout During an Outbreak of Middle East Respiratory Syndrome Coronavirus in Korea. Asian nursing research 2016;10(4):295-99.

44. Koh D, Lim MK, Chia SE, et al. Risk Perception and Impact of Severe Acute Respiratory Syndrome (SARS) on Work and Personal Lives of Healthcare Workers in Singapore: What Can We Learn? Medical Care 2005;43(7):676-82.

45. Fiksenbaum L, Marjanovic Z, Greenglass ER, et al. Emotional exhaustion and state anger in nurses who worked during the sars outbreak: The role of perceived threat and organizational support. Can J Community Ment Health 2006;25(2):89-103.

46. Lai J, Ma S, Wang Y, et al. Factors Associated With Mental Health Outcomes Among Health Care Workers Exposed to Coronavirus Disease 2019. JAMA Network Open 2020;3(3):e203976-e76. doi: 10.1001/jamanetworkopen.2020.3976

47. Lancee WJ, Maunder RG, Goldbloom DS. Prevalence of psychiatric disorders among Toronto hospital workers one to two years after the SARS outbreak. Psychiatric Services 2008;59(1):91-95.

48. Lee AM, Wong JGWS, McAlonan GM, et al. Stress and psychological distress among SARS survivors 1 year after the outbreak. Canadian journal of psychiatry Revue canadienne de psychiatrie 2007;52(4):233-40.

49. Lee $S-H$, Juang $Y-Y$, Su Y-J, et al. Facing SARS: psychological impacts on SARS team nurses and psychiatric services in a Taiwan general hospital. General hospital psychiatry 2005;27(5):352-8.

50. Lee SM, Kang WS, Cho A-R, et al. Psychological impact of the 2015 MERS outbreak on hospital workers and quarantined hemodialysis patients. Comprehensive psychiatry 2018;87:123-27. 
medRxiv preprint doi: https://doi.org/10.1101/2020.04.02.20048892; this version posted April 6, 2020. The copyright holder for this preprint (which was not certified by peer review) is the author/funder, who has granted medRxiv a license to display the preprint in perpetuity. It is made available under a CC-BY-ND 4.0 International license .

51. Lehmann M, Bruenahl CA, Addo MM, et al. Acute Ebola virus disease patient treatment and health-related quality of life in health care professionals: A controlled study. Journal of psychosomatic research 2016;83(376333):69-74.

52. Li L, Wan C, Ding R, et al. Mental distress among Liberian medical staff working at the China Ebola Treatment Unit: a cross sectional study. Health and quality of life outcomes 2015;13(101153626):156.

53. Li Z, Ge J, Yang M, et al. Vicarious traumatization in the general public, members, and nonmembers of medical teams aiding in COVID-19 control. Brain, behavior, and immunity 2020

54. Lin $\mathrm{C}-\mathrm{Y}$, Peng $\mathrm{Y}-\mathrm{C}$, Wu Y-H, et al. The psychological effect of severe acute respiratory syndrome on emergency department staff. Emergency medicine journal : EMJ 2007;24(1):12-7.

55. Liu X, Kakade M, Fuller CJ, et al. Depression after exposure to stressful events: lessons learned from the severe acute respiratory syndrome epidemic. Comprehensive psychiatry 2012;53(1):15-23.

56. Loh L-C, Ali AM, Ang T-H, et al. Impact of a spreading epidemic on medical students. The Malaysian journal of medical sciences : MJMS 2006;13(2):30-6.

57. Lu Y-C, Shu B-C, Chang Y-Y, et al. The mental health of hospital workers dealing with severe acute respiratory syndrome. Psychotherapy and psychosomatics 2006;75(6):370-5.

58. Lung F-W, Lu Y-C, Chang Y-Y, et al. Mental Symptoms in Different Health Professionals During the SARS Attack: A Follow-up Study. The Psychiatric quarterly 2009;80(2):10716.

59. Marjanovic Z, Greenglass ER, Coffey S. The relevance of psychosocial variables and working conditions in predicting nurses' coping strategies during the SARS crisis: an online questionnaire survey. International journal of nursing studies 2007;44(6):991-8.

60. Matsuishi K, Kawazoe A, Imai H, et al. Psychological impact of the pandemic (H1N1) 2009 on general hospital workers in Kobe. Psychiatry and clinical neurosciences 2012;66(4):353-60.

61. Maunder RG, Lancee WJ, Balderson KE, et al. Long-term psychological and occupational effects of providing hospital healthcare during SARS outbreak. Emerging infectious diseases 2006;12(12):1924-32.

62. Maunder RG, Lancee WJ, Mae R, et al. Computer-assisted resilience training to prepare healthcare workers for pandemic influenza: a randomized trial of the optimal dose of training. BMC health services research 2010;10(101088677):72.

63. Maunder RG, Lancee WJ, Rourke $S$, et al. Factors associated with the psychological impact of severe acute respiratory syndrome on nurses and other hospital workers in Toronto. Psychosomatic medicine 2004;66(6):938-42.

64. McAlonan GM, Lee AM, Cheung V, et al. Immediate and sustained psychological impact of an emerging infectious disease outbreak on health care workers. Canadian journal of psychiatry Revue canadienne de psychiatrie 2007;52(4):241-7.

65. Nickell LA, Crighton EJ, Tracy CS, et al. Psychosocial effects of SARS on hospital staff: survey of a large tertiary care institution. CMAJ : Canadian Medical Association journal = journal de l'Association medicale canadienne 2004;170(5):793-8.

66. Oh N, Hong N, Ryu DH, et al. Exploring Nursing Intention, Stress, and Professionalism in Response to Infectious Disease Emergencies: The Experience of Local Public Hospital Nurses During the 2015 MERS Outbreak in South Korea. Asian nursing research 2017; 11(3):230-36.

67. Park J-S, Lee E-H, Park N-R, et al. Mental Health of Nurses Working at a Governmentdesignated Hospital During a MERS-CoV Outbreak: A Cross-sectional Study. Archives of psychiatric nursing 2018;32(1):2-6. 
medRxiv preprint doi: https://doi.org/10.1101/2020.04.02.20048892; this version posted April 6, 2020. The copyright holder for this preprint (which was not certified by peer review) is the author/funder, who has granted medRxiv a license to display the preprint in perpetuity. It is made available under a CC-BY-ND 4.0 International license .

68. Phua DH, Tang HK, Tham KY. Coping responses of emergency physicians and nurses to the 2003 severe acute respiratory syndrome outbreak. Academic emergency medicine : official journal of the Society for Academic Emergency Medicine 2005;12(4):322-8.

69. Poon E, Liu KS, Cheong DL, et al. Impact of severe respiratory syndrome on anxiety levels of front-line health care workers. Hong Kong medical journal = Xianggang yi xue za zhi 2004;10(5):325-30.

70. Schreiber M, Cates DS, Formanski S, et al. Maximizing the Resilience of Healthcare Workers in Multi-hazard Events: Lessons from the 2014-2015 Ebola Response in Africa. Military medicine 2019;184:114-20.

71. Sim K, Chong PN, Chan YH, et al. Severe acute respiratory syndrome-related psychiatric and posttraumatic morbidities and coping responses in medical staff within a primary health care setting in Singapore. The Journal of clinical psychiatry 2004;65(8):1120-7.

72. Styra R, Hawryluck L, Robinson S, et al. Impact on health care workers employed in highrisk areas during the Toronto SARS outbreak. Journal of psychosomatic research 2008;64(2):177-83.

73. Su T-P, Lien T-C, Yang C-Y, et al. Prevalence of psychiatric morbidity and psychological adaptation of the nurses in a structured SARS caring unit during outbreak: a prospective and periodic assessment study in Taiwan. Journal of psychiatric research 2007;41(1):119-30.

74. Tam CWC, Pang EPF, Lam LCW, et al. Severe acute respiratory syndrome (SARS) in Hong Kong in 2003: stress and psychological impact among frontline healthcare workers. Psychological medicine 2004;34(7):1197-204.

75. Tang L, Pan L, Yuan L, et al. Prevalence and related factors of post-traumatic stress disorder among medical staff members exposed to H7N9 patients. International journal of nursing sciences 2017;4(1):63-67.

76. Tolomiczenko GS, Kahan M, Ricci M, et al. SARS: coping with the impact at a community hospital. Journal of advanced nursing 2005;50(1):101-10.

77. Verma S, Mythily S, Chan YH, et al. Post-SARS psychological morbidity and stigma among general practitioners and traditional Chinese medicine practitioners in Singapore. Annals of the Academy of Medicine, Singapore 2004;33(6):743-8.

78. Wong TW, Yau JKY, Chan CLW, et al. The psychological impact of severe acute respiratory syndrome outbreak on healthcare workers in emergency departments and how they cope. European journal of emergency medicine : official journal of the European Society for Emergency Medicine 2005;12(1):13-8.

79. Wong WC, Wong SY, Lee A, et al. How to provide an effective primary health care in fighting against severe acute respiratory syndrome: the experiences of two cities. American journal of infection control 2007;35(1):50-5. doi: 10.1016/j.ajic.2006.06.009 [published Online First: 2007/02/06]

80. Wong WCW, Lee A, Tsang KK, et al. How did general practitioners protect themselves, their family, and staff during the SARS epidemic in Hong Kong? Journal of epidemiology and community health 2004;58(3):180-5.

81. Wu P, Fang Y, Guan Z, et al. The psychological impact of the SARS epidemic on hospital employees in China: Exposure, risk perception, and altruistic acceptance of risk. The Canadian Journal of Psychiatry / La Revue canadienne de psychiatrie 2009;54(5):30211.

82. Wu P, Liu X, Fang Y, et al. Alcohol abuse/dependence symptoms among hospital employees exposed to a SARS outbreak. Alcohol and alcoholism (Oxford, Oxfordshire) 2008;43(6):706-12.

83. Xiao H, Zhang Y, Kong D, et al. The Effects of Social Support on Sleep Quality of Medical Staff Treating Patients with Coronavirus Disease 2019 (COVID-19) in January and February 2020 in China. Medical science monitor : international medical journal of experimental and clinical research 2020;26:e923549. 
medRxiv preprint doi: https://doi.org/10.1101/2020.04.02.20048892; this version posted April 6, 2020. The copyright holder for this preprint (which was not certified by peer review) is the author/funder, who has granted medRxiv a license to display the preprint in perpetuity. It is made available under a CC-BY-ND 4.0 International license .

84. Folkman S, Greer S. Promoting psychological well-being in the face of serious illness: when theory, research and practice inform each other. Psycho-Oncology: Journal of the Psychological, Social and Behavioral Dimensions of Cancer 2000;9(1):11-19.

85. de Rooij D, Belfroid E, Eilers R, et al. Qualitative Research: Institutional Preparedness During Threats of Infectious Disease Outbreaks. BioMed research international 2020;2020:5861894. doi: 10.1155/2020/5861894 [published Online First: 2020/02/25]

86. Gonçalves-Bradley DC, Buckley BS, Fønhus MS, et al. Mobile-based technologies to support healthcare provider to healthcare provider communication and management of care. Cochrane Database of Systematic Reviews 2018(1) doi: 10.1002/14651858.CD012927

87. Hoffmann TC, Glasziou PP, Boutron I, et al. Better reporting of interventions: template for intervention description and replication (TIDieR) checklist and guide. BMJ : British Medical Journal 2014;348:g1687. doi: 10.1136/bmj.g1687 
medRxiv preprint doi: https://doi.org/10.1101/2020.04.02.20048892; this version posted April 6, 2020. The copyright holder for this preprint (which was not certified by peer review) is the author/funder, who has granted medRxiv a license to display the preprint in perpetuity. It is made available under a CC-BY-ND 4.0 International license .

\section{Online Appendix 1. Search strategies}

Medline (Ovid): 23 March 2020

\begin{tabular}{|c|c|c|}
\hline & Searches & Hits \\
\hline 1 & $\begin{array}{l}\text { exp Health Personnel/ or ((health or health care or healthcare) adj2 (personnel or } \\
\text { worker* or provider* or employee* or staff or professional*)).tw. or ((medical or } \\
\text { hospital) adj2 (staff or employee* or personnel or worker*)).tw. or (doctor* or } \\
\text { physician* or clinician*).tw. or (allied health adj2 (staff or personnel or } \\
\text { worker*)).tw. or paramedic*.tw. or nurse*.tw. or (nursing adj2 (staff or personnel or } \\
\text { auxiliar*)).tw. }\end{array}$ & 1379427 \\
\hline 2 & $\begin{array}{l}\text { mental disorders/ or exp adjustment disorders/ or exp anxiety disorders/ or exp } \\
\text { mood disorders/ or neurotic disorders/ or mental health.mp. }\end{array}$ & 466605 \\
\hline 3 & $\begin{array}{l}\text { (anxi* or depress* or melancholi* or neuros* or neurotic or psychoneuro* or stress* } \\
\text { or distress* or emotion*).tw. }\end{array}$ & 1614503 \\
\hline 4 & affective symptom*.mp. & 14631 \\
\hline 5 & 2 or 3 or 4 & 1882229 \\
\hline 6 & $\begin{array}{l}\text { Disease Outbreaks.mp. [mp=title, abstract, original title, name of substance word, } \\
\text { subject heading word, floating sub-heading word, keyword heading word, organism } \\
\text { supplementary concept word, protocol supplementary concept word, rare disease } \\
\text { supplementary concept word, unique identifier, synonyms] }\end{array}$ & 80952 \\
\hline 7 & exp *Disease Outbreaks/ & 61132 \\
\hline 8 & $\begin{array}{l}\text { pandemic*.mp. [mp=title, abstract, original title, name of substance word, subject } \\
\text { heading word, floating sub-heading word, keyword heading word, organism } \\
\text { supplementary concept word, protocol supplementary concept word, rare disease } \\
\text { supplementary concept word, unique identifier, synonyms] }\end{array}$ & 24932 \\
\hline 9 & $\begin{array}{l}\text { epidemic.mp. [mp=title, abstract, original title, name of substance word, subject } \\
\text { heading word, floating sub-heading word, keyword heading word, organism } \\
\text { supplementary concept word, protocol supplementary concept word, rare disease } \\
\text { supplementary concept word, unique identifier, synonyms] }\end{array}$ & 89450 \\
\hline 10 & exp *Coronaviridae Infections/ or exp *Coronaviridae/ & 14403 \\
\hline 11 & exp *Coronavirus/ & 9573 \\
\hline 12 & covid 19.mp. & 993 \\
\hline 13 & covid-19.mp. & 993 \\
\hline 14 & exp *SARS Virus/ & 2321 \\
\hline 15 & exp *Hemorrhagic Fever, Ebola/ & 4618 \\
\hline 16 & $\begin{array}{l}\text { exp *Influenza, Human/ or exp *Influenza A Virus, H1N1 Subtype/ or exp *Influenza } \\
\text { A virus/ }\end{array}$ & 59684 \\
\hline
\end{tabular}


medRxiv preprint doi: https://doi.org/10.1101/2020.04.02.20048892; this version posted April 6, 2020. The copyright holder for this preprint (which was not certified by peer review) is the author/funder, who has granted medRxiv a license to display the preprint in perpetuity.

It is made available under a CC-BY-ND 4.0 International license.

\begin{tabular}{|r|l|r|}
\hline 17 & health crisis.mp. & 2070 \\
\hline 18 & emergency crisis.mp. & 44 \\
\hline 19 & 6 or 7 or 8 or 9 or 10 or 11 or 12 or 13 or 14 or 15 or 16 or 17 or 18 & 1252 \\
\hline 20 & 1 and 5 and 19 & \\
\hline
\end{tabular}


medRxiv preprint doi: https://doi.org/10.1101/2020.04.02.20048892; this version posted April 6, 2020. The copyright holder for this preprint

(which was not certified by peer review) is the author/funder, who has granted medRxiv a license to display the preprint in perpetuity.

It is made available under a CC-BY-ND 4.0 International license.

PsycINFO (EBSCO): 23 March 2020

\begin{tabular}{|r|l|r|}
\hline & Searches & Hits \\
\hline 1 & $\begin{array}{l}\text { TI ( healthcare professionals or healthcare workers or healthcare providers or physician } \\
\text { or nurse or doctor ) OR AB ( healthcare professionals or healthcare workers or } \\
\text { healthcare providers or physician or nurse or doctor ) }\end{array}$ & 163,295 \\
\hline 2 & DE mental health & 70,131 \\
\hline 3 & $\begin{array}{l}\text { TI ( mental health or mental illness or mental disorder or psychiatric illness ) OR AB ( } \\
\text { mental health or mental illness or mental disorder or psychiatric illness ) }\end{array}$ & 250,928 \\
\hline 4 & DE depression & 44,673 \\
\hline 5 & DE anxiety & 78,469 \\
\hline 6 & $\begin{array}{l}\text { TI ( depression or depressive disorder or depressive symptoms or major depressive } \\
\text { disorder ) OR AB ( depression or depressive disorder or depressive symptoms or major } \\
\text { depressive disorder ) }\end{array}$ & 265,842 \\
\hline 7 & $\begin{array}{l}\text { TI ( anxiety disorders or anxiety or generalized anxiety disorder ) OR AB ( anxiety } \\
\text { disorders or anxiety or generalized anxiety disorder ) }\end{array}$ & 191,246 \\
\hline 8 & S2 OR S3 OR S4 OR S5 OR S6 OR S7 & $\begin{array}{l}\text { Tl ( coronavirus or covid-19 or sars or mers or pandemic or outbreak ) OR AB ( } \\
\text { coronavirus or covid-19 or sars or mers or pandemic or outbreak ) }\end{array}$ \\
\hline 13 & S9 OR S10 OR S11 OR S12 & 16,427 \\
\hline 14 & S1 AND S8 AND S13 & $\begin{array}{l}\text { TI ( disease outbreaks or pandemic or epidemic or health emergency ) OR AB ( disease } \\
\text { outbreaks or pandemic or epidemic or health emergency ) }\end{array}$ \\
\hline 11 & DE coronavirus & 9032 \\
\hline
\end{tabular}


medRxiv preprint doi: https://doi.org/10.1101/2020.04.02.20048892; this version posted April 6, 2020. The copyright holder for this preprint

(which was not certified by peer review) is the author/funder, who has granted medRxiv a license to display the preprint in perpetuity.

It is made available under a CC-BY-ND 4.0 International license .

Embase (Elsevier): 23 March 2020

\begin{tabular}{|c|c|c|}
\hline & Searches & Hits \\
\hline 1 & 'health care personnel'/exp OR 'health care personnel' & $1,538,012$ \\
\hline 2 & $\begin{array}{l}\text { health NEXT/2 } \\
\text { (personnel OR worker* OR provider* OR employee* OR staff OR professional*) }\end{array}$ & 399,604 \\
\hline 3 & $\begin{array}{l}\text { 'health care' NEXT/2 } \\
\text { (personnel OR worker* OR provider* OR employee* OR staff OR professional*) }\end{array}$ & 217,126 \\
\hline 4 & $\begin{array}{l}\text { healthcare NEXT/2 } \\
\text { (personnel OR worker* OR provider* OR employee* OR staff OR professional*) }\end{array}$ & 85,747 \\
\hline 5 & medical NEAR/2 (staff OR employee* OR personnel OR worker*) & 68,132 \\
\hline 6 & hospital NEAR/2 (staff OR employee* OR personnel OR worker*) & 37,505 \\
\hline 7 & doctor* OR physician* OR clinician* & $1,432,241$ \\
\hline 8 & 'allied health' NEAR/2 (staff OR personnel OR worker*) & 978 \\
\hline 9 & paramedic* OR nurse* & 542,98 \\
\hline 10 & nursing NEAR/2 (staff OR personnel OR auxiliar*) & 82,598 \\
\hline 11 & \#1 OR \#2 OR \#3 OR \#4 OR \#5 OR \#6 OR \#7 OR \#8 OR \#9 OR \#10 & $2,845,394$ \\
\hline 12 & 'mental health'/exp OR 'mental health' & 460,848 \\
\hline 13 & 'mental disease'/exp OR 'mental disease' & $2,284,001$ \\
\hline 14 & $\begin{array}{l}\text { anxi* OR depress* OR melancholi* OR neuros* OR neurotic OR psychoneuro* OR stre } \\
\text { ss* OR distress* OR emotion* }\end{array}$ & $3,662,310$ \\
\hline 15 & 'affective symptom*' & 3,096 \\
\hline 16 & \#12 OR \#13 OR \#14 OR \#15 & $5,081,304$ \\
\hline 17 & 'epidemic'/exp OR 'epidemic' & 177,563 \\
\hline 18 & 'pandemic'/exp OR 'pandemic' & 30,568 \\
\hline 19 & 'coronavirus infection'/exp OR 'coronavirus infection' & 11,65 \\
\hline 20 & covid AND 19 OR covid19 OR 'covid 19' & 378 \\
\hline 21 & 'sars-related coronavirus'/exp OR 'sars-related coronavirus' & 4,657 \\
\hline 22 & 'ebolavirus'/exp OR 'ebolavirus' & 5,873 \\
\hline 23 & 'influenza'/exp OR 'influenza' & 155,881 \\
\hline 24 & 'health crisis' OR 'emergency crisis' & 3,215 \\
\hline 25 & \#17 OR \#18 OR \#19 OR \#20 OR \#21 OR \#22 OR \#23 OR \#24 & 339,775 \\
\hline
\end{tabular}


medRxiv preprint doi: https://doi.org/10.1101/2020.04.02.20048892; this version posted April 6, 2020. The copyright holder for this preprint (which was not certified by peer review) is the author/funder, who has granted medRxiv a license to display the preprint in perpetuity. It is made available under a CC-BY-ND 4.0 International license.

\begin{tabular}{|r|l|r|}
\hline 26 & $\# 11$ AND \#16 AND \#25 & 5,981 \\
\hline 27 & $\begin{array}{l}\text { \#26 AND [embase]/lim NOT ([embase]/lim AND [medline]/lim) AND 'human'/de AND } \\
\text { ('article'/it OR 'article in press'/it OR 'review'/it) }\end{array}$ & 660 \\
\hline
\end{tabular}


medRxiv preprint doi: https://doi.org/10.1101/2020.04.02.20048892; this version posted April 6, 2020. The copyright holder for this preprint (which was not certified by peer review) is the author/funder, who has granted medRxiv a license to display the preprint in perpetuity. It is made available under a CC-BY-ND 4.0 International license .

\section{Online Appendix 2. List of excluded papers after full-text screening}

* Excluded due to wrong study population (i.e., not healthcare professionals)

1. Gardner PJ, Moallef P. Psychological impact on SARS survivors: Critical review of the English language literature. Canadian Psychology/Psychologie canadienne. 2015;56(1):123-35. 2. Sipos ML, Kim PY, Thomas SJ, Adler AB. U.S. Service Member Deployment in Response to the Ebola Crisis: The Psychological Perspective. Military medicine. 2018;183(3):e171-e8. 3. Wong TW, Gao Y, San Tam WW. Anxiety among university students during the SARS epidemic in Hong Kong. Stress Health. 2007;23(1):31-5.

* Excluded due to wrong outcome (i.e., impact on mental health not examined)

1. Alsahafi AJ, Cheng AC. Knowledge, Attitudes and Behaviours of Healthcare Workers in the Kingdom of Saudi Arabia to MERS Coronavirus and Other Emerging Infectious Diseases. International journal of environmental research and public health. 2016;13(12).

2. Bar-Dayan $\mathrm{Y}$, Boldor N, Kremer I, London M, Levy R, Barak MI, et al. Who is willing to risk his life for a patient with a potentially fatal, communicable disease during the peak of A/H1N1 pandemic in Israel? Journal of emergencies, trauma, and shock. 2011;4(2):184-7.

3. Chang CS, Du PL, Huang IC. Nurses' perceptions of severe acute respiratory syndrome: relationship between commitment and intention to leave nursing. Journal of advanced nursing. 2006;54(2):171-9.

4. Cohen MA, Cohen SC. AIDS education and a volunteer training program for medical students. Psychosomatics: Journal of Consultation and Liaison Psychiatry. 1991;32(2):187-90. 5. Considine J, Shaban RZ, Patrick J, Holzhauser K, Aitken P, Clark M, et al. Pandemic (H1N1) 2009 Influenza in Australia: Absenteeism and redeployment of emergency medicine and nursing staff. Emergency medicine Australasia : EMA. 2011;23(5):615-23.

6. El Gaafary MM, Abd Elaziz KM, Abdel-Rahman AG, Allam MF. Concerns, perceived impacts and preparedness of health care workers in a referral hospital in Egypt in facing influenza (H1N1) epidemic. Journal of preventive medicine and hygiene. 2010;51(3):105-9. 7. Honey $M$, Wang WYQ. New Zealand nurses perceptions of caring for patients with influenza A (H1N1). Nursing in critical care. 2013;18(2):63-9.

8. Hope K, Merritt T, Eastwood K, Main K, Durrheim DN, Muscatello D, et al. The public health value of emergency department syndromic surveillance following a natural disaster. Communicable diseases intelligence quarterly report. 2008;32(1):92-4.

9. Imai H, Matsuishi K, Ito A, Mouri K, Kitamura N, Akimoto K, et al. Factors associated with motivation and hesitation to work among health professionals during a public crisis: a cross sectional study of hospital workers in Japan during the pandemic (H1N1) 2009. BMC public health. 2010;10(100968562):672.

10. Kim CJ, Yoo HR, Yoo MS, Kwon BE, Hwang KJ. Attitude, beliefs, and intentions to care for SARS patients among Korean clinical nurses: an application of theory of planned behavior. Taehan Kanho Hakhoe chi. 2006;36(4):596-603.

11. de Saxe Zerden L, Zerden ML, Billinghurst KG. Caring for home-based care workers. Understanding the needs, fears and motivations of front-line care workers in South Africa. South Afr J HIV Med. 2006(24):38-43.

12. Lateef F, Lim SH, Tan EH. New paradigm for protection: the emergency ambulance services in the time of severe acute respiratory syndrome. Prehospital emergency care : official journal of the National Association of EMS Physicians and the National Association of State EMS Directors. 2004;8(3):304-7. 
medRxiv preprint doi: https://doi.org/10.1101/2020.04.02.20048892; this version posted April 6, 2020. The copyright holder for this preprint (which was not certified by peer review) is the author/funder, who has granted medRxiv a license to display the preprint in perpetuity. It is made available under a CC-BY-ND 4.0 International license .

13. Pratt $M$, Kerr $M$, Wong $C$. The impact of ERI, burnout, and caring for SARS patients on hospital nurses' self-reported compliance with infection control. The Canadian journal of infection control : the official journal of the Community \& Hospital Infection Control Association-Canada $=$ Revue canadienne de prevention des infections. 2009;24(3):167-74.

14. Vinck L, Isken L, Hooiveld M, Trompenaars M, Ijzermans J, Timen A. Impact of the 2009 influenza $A(\mathrm{H} 1 \mathrm{~N} 1)$ pandemic on public health workers in the Netherlands. Euro surveillance : bulletin Europeen sur les maladies transmissibles = European communicable disease bulletin. 2011;16(7).

15. von Strauss E, Paillard-Borg S, Holmgren J, Saaristo P. Global nursing in an Ebola viral haemorrhagic fever outbreak: before, during and after deployment. Global health action. 2017;10(1):1371427.

16. Wong TY, Koh GC, Cheong SK, Lee HY, Fong YT, Sundram M, et al. Concerns, perceived impact and preparedness in an avian influenza pandemic--a comparative study between healthcare workers in primary and tertiary care. Annals of the Academy of Medicine, Singapore. 2008;37(2):96-102.

17. Wong TY, Koh GCH, Cheong SK, Sundram M, Koh K, Chia SE, et al. A cross-sectional study of primary-care physicians in Singapore on their concerns and preparedness for an avian influenza outbreak. Annals of the Academy of Medicine, Singapore. 2008;37(6):458-64.

* Excluded due to wrong context (i.e., not during or after a health emergency caused by an epidemic/pandemic).

1. Bakhamis L, Paul DPr, Smith H, Coustasse A. Still an Epidemic: The Burnout Syndrome in Hospital Registered Nurses. The health care manager. 2019;38(1):3-10.

2. Carnes BA. Caring for the professional caregiver: the application of Caplan's model of consultation in the era of HIV. Issues in mental health nursing. 1992;13(4):357-67.

3. Sacadura-Leite E, Sousa-Uva A, Rebelo-De-Andrade H, Ferreira S, Rocha R.

Association between chronic stress and immune response to influenza vaccine in healthcare workers. Revista Port Saude Publica. 2014;32(1):18-26.

4. Goldberg MJ, Shea KG, Weiss JM, Carter CW, Talwalkar VR, Schwend RM. The Pediatric Orthopaedic Society of North America (POSNA) Adopts a Member Health and Wellness Charter. Journal of pediatric orthopedics. 2019;39(4):e241-e4.

5. Horner G, Daddona J, Burke DJ, Cullinane J, Skeer M, Wurcel AG. "You're kind of at war with yourself as a nurse": Perspectives of inpatient nurses on treating people who present with a comorbid opioid use disorder. PloS one. 2019;14(10):e0224335.

6. Letourneau LM, Ritzo J, Shonk R, Eichler M, Sy S. Supporting Physicians and Practice Teams in Efforts to Address the Opioid Epidemic. Annals of family medicine. 2019;17:S77-S81.

7. Magidson JF, Joska JA, Regenauer KS, Satinsky E, Andersen LS, Seitz-Brown CJ, et al. "Someone who is in this thing that I am suffering from": The role of peers and other facilitators for task sharing substance use treatment in South African HIV care. The International journal on drug policy. 2019;70(9014759):61-9.

8. McKinney BK. Withstanding the pressure of the profession. Journal for nurses in staff development : JNSD : official journal of the National Nursing Staff Development Organization. 2011;27(2):69-73.

9. McNicholas F, Sharma S, Oconnor C, Barrett E. Burnout in consultants in child and adolescent mental health services (CAMHS) in Ireland: a cross-sectional study. BMJ open. 2020;10(1):e030354.

10. Mohangi K, Pretorius C. On the periphery of HIV and AIDS: Reflections on stress as experienced by caregivers in a child residential care facility in South Africa. SAHARA J : journal of Social Aspects of HIV/AIDS Research Alliance. 2017;14(1):153-61. 
medRxiv preprint doi: https://doi.org/10.1101/2020.04.02.20048892; this version posted April 6, 2020. The copyright holder for this preprint

(which was not certified by peer review) is the author/funder, who has granted medRxiv a license to display the preprint in perpetuity.

It is made available under a CC-BY-ND 4.0 International license.

11. O'Boyle C, Robertson C, Secor-Turner M. Public health emergencies: nurses' recommendations for effective actions. AAOHN journal : official journal of the American Association of Occupational Health Nurses. 2006;54(8):347-53.

12. Sexton JB, Adair KC. Forty-five good things: a prospective pilot study of the Three Good Things well-being intervention in the USA for healthcare worker emotional exhaustion, depression, work-life balance and happiness. BMJ open. 2019;9(3):e022695.

13. Watt K, Tippett VC, Raven SG, Jamrozik K, Coory M, Archer F, et al. Attitudes to living and working in pandemic conditions among emergency prehospital medical care personnel. Prehospital and disaster medicine. 2010;25(1):13-9.

14. Wong ELY, Wong SYS, Kung K, Cheung AWL, Gao TT, Griffiths S. Will the community nurse continue to function during H1N1 influenza pandemic: a cross-sectional study of Hong Kong community nurses? BMC health services research. 2010;10(101088677):107.

* Excluded due to wrong study design (e.g. qualitative studies, case studies, etc.)

1. Almutairi AF, Adlan AA, Balkhy HH, Abbas OA, Clark AM. "It feels like I'm the dirtiest person in the world.": Exploring the experiences of healthcare providers who survived MERSCoV in Saudi Arabia. Journal of infection and public health. 2018;11(2):187-91.

2. Amaratunga CA, O'Sullivan TL, Phillips KP, Lemyre L, O'Connor E, Dow D, et al. Ready, aye ready? Support mechanisms for healthcare workers in emergency planning: a critical gap analysis of three hospital emergency plans. American journal of disaster medicine.

2007;2(4):195-210.

3. Chalk M. The psychological effects of working at an Ebola treatment centre. British journal of nursing (Mark Allen Publishing). 2017;26(3):178-9.

4. Englert EG, Kiwanuka R, Neubauer LC. 'When I die, let me be the last.' Community health worker perspectives on past Ebola and Marburg outbreaks in Uganda. Global public health. 2019;14(8):1182-92.

5. Lau PY, Chan CWH. SARS (severe acute respiratory syndrome): reflective practice of a nurse manager. Journal of clinical nursing. 2005;14(1):28-34.

6. Li Y, Wang $H$, Jin X-R, Li X, Pender $M$, Song $C-P$, et al. Experiences and challenges in the health protection of medical teams in the Chinese Ebola treatment center, Liberia: a qualitative study. Infectious diseases of poverty. 2018;7(1):92.

7. McMullan C, Brown GD, O'Sullivan D. Preparing to respond: Irish nurses' perceptions of preparedness for an influenza pandemic. International emergency nursing. 2016;26(101472191):3-7.

8. O'Sullivan TL, Amaratunga CA, Hardt J, Dow D, Phillips KP, Corneil W. Are we ready? Evidence of support mechanisms for Canadian health care workers in multi-jurisdictional emergency planning. Canadian journal of public health $=$ Revue canadienne de sante publique . 2007;98(5):358-63.

9. Smith E, Burkle FM, Gebbie K, Ford D, Bensimon C. Acceptable Limitations on Paramedic Duty to Treat During Disaster: A Qualitative Exploration. Prehospital and disaster medicine. 2018;33(5):466-70.

10. Xi Y, Chen R, Gillespie AL, He Y, Jia C, Shi K, et al. Mental health workers perceptions of disaster response in China. BMC public health. 2019;19(1):11.

* Excluded due to wrong publication type (narrative reviews, thesis, editorials, protocols, and editor letters) 
medRxiv preprint doi: https://doi.org/10.1101/2020.04.02.20048892; this version posted April 6, 2020. The copyright holder for this preprint (which was not certified by peer review) is the author/funder, who has granted medRxiv a license to display the preprint in perpetuity. It is made available under a CC-BY-ND 4.0 International license .

1. Belfroid E, van Steenbergen J, Timen A, Ellerbroek P, Huis A, Hulscher M. Preparedness and the importance of meeting the needs of healthcare workers: a qualitative study on Ebola. The Journal of hospital infection. 2018;98(2):212-8.

2. Hall RCW, Hall RCW, Chapman MJ. The 1995 Kikwit Ebola outbreak: lessons hospitals and physicians can apply to future viral epidemics. General hospital psychiatry. 2008;30(5):446-52.

3. Committee on Crisis Standards of Care: A Toolkit for Indicators and Triggers; Board on Health Sciences Policy; Institute of Medicine; Hanfling D, Hick JL, Stroud C, editors. Washington (DC): National Academies Press (US); 2013 Sep 27.

4. Kang L, Li Y, Hu S, Chen M, Yang C, Yang BX, et al. The mental health of medical workers in Wuhan, China dealing with the 2019 novel coronavirus. The Lancet Psychiatry. 2020;7(3):e14.

5. Kuper H, Lyra TM, Moreira MEL, de Albuquerque MdSV, de Araujo TVB, Fernandes S, et al. Social and economic impacts of congenital Zika syndrome in Brazil: Study protocol and rationale for a mixed-methods study. Wellcome open research. 2018;3(101696457):127.

6. Lehmann M, Bruenahl CA, Lowe B, Addo MM, Schmiedel S, Lohse AW, et al. Ebola and psychological stress of health care professionals. Emerging infectious diseases. 2015;21(5):9134.

7. Macks JA, Abrams DI. Burnout among HIV/AIDS health care providers. Helping the people on the frontlines. AIDS clinical review. 1992:281-99.

8. Makamure M, Makamure M, Mendiola W, Renteria D, Repp M, Willden A. A review of critical care nursing and disease outbreak preparedness. Dimensions of critical care nursing : DCCN. 2013;32(4):157-61.

9. Maunder RG. Was SARS a mental health catastrophe? General Hospital Psychiatry. 2009;31(4):316-7.

10. Maunder RG, Leszcz M, Savage D, Adam MA, Peladeau N, Romano D, et al. Applying the lessons of SARS to pandemic influenza: an evidence-based approach to mitigating the stress experienced by healthcare workers. Canadian journal of public health $=$ Revue canadienne de sante publique. 2008;99(6):486-8.

11. Paladino L, Sharpe RP, Galwankar SC, Sholevar F, Marchionni C, Papadimos TJ, et al. Reflections on the Ebola Public Health Emergency of International Concern, Part 2: The Unseen Epidemic of Posttraumatic Stress among Health-care Personnel and Survivors of the 2014-2016 Ebola Outbreak. Journal of global infectious diseases. 2017;9(2):45-50.

12. Singh R, Tadi P, Marlowe D. Provider Burnout. 2019.

13. Spiers J, Buszewicz M, Chew-Graham C, Gerada C, Kessler D, Leggett N, et al. Who cares for the clinicians? The mental health crisis in the GP workforce. The British journal of general practice : the journal of the Royal College of General Practitioners. 2016;66(648):3445.

14. Sprecher A, Van Herp M, Rollin PE. Clinical Management of Ebola Virus Disease Patients in Low-Resource Settings. Current topics in microbiology and immunology. 2017;411:93-113.

15. Srivatsa S, Stewart KA. How Should Clinicians Integrate Mental Health Into Epidemic Responses? AMA journal of ethics. 2020;22(1):E10-5.

16. Tosh PK, Sampathkumar P. What clinicians should know about the 2014 Ebola outbreak. Mayo Clinic proceedings. 2014;89(12):1710-7.

17. Ulrich CM. Ebola is causing moral distress among African healthcare workers. BMJ (Clinical research ed). 2014;349(8900488):g6672.

18. Chen Q, Liang M, Li Y, Guo J, Fei D, Wang L, et al. Mental health care for medical staff in China during the COVID-19 outbreak. The Lancet Psychiatry. 2020(101638123).

* Excluded due to language (publication not in English, Spanish, or Portuguese) 
medRxiv preprint doi: https://doi.org/10.1101/2020.04.02.20048892; this version posted April 6, 2020. The copyright holder for this preprint (which was not certified by peer review) is the author/funder, who has granted medRxiv a license to display the preprint in perpetuity. It is made available under a CC-BY-ND 4.0 International license .

1. Chiang $\mathrm{H}-\mathrm{H}$, Chen M-B, Sue I-L. [Ethical dilemmas in caring for patients with SARS]. Hu li za zhi The journal of nursing. 2006;53(5):28-34.

2. Huang JZ, Han MF, Luo TD, Ren AK, Zhou XP. [Mental health survey of 230 medical staff in a tertiary infectious disease hospital for COVID-19]. Zhonghua lao dong wei sheng zhi ye bing za zhi = Zhonghua laodong weisheng zhiyebing zazhi $=$ Chinese journal of industrial hygiene and occupational diseases. 2020;38:E001.

3. Huang $W$, Hua $Q, W u H, X u ~ W-y$, Tian J-h, Chen $H$, et al. [A study on the differences of emotion and depression between patients as doctor/nurse and others occupation with severe acute respiratory syndrome]. Zhonghua liu xing bing xue za zhi = Zhonghua liuxingbingxue zazhi. 2004;25(1):23-6.

4. Zhang KR, Xu Y, Liu ZG, Yang H, Song LP, Xue YZ, et al. Controlled study of posttraumatic stress disorder among patients with severe acute respiratory syndrome and first-line hospital staffs as well as public in prevalent areas. Chin J Clin Rehab. 2005;9(12):94-6. 5. Zhang $Q$, Yang XL, Huang XQ, He XB. Attitude of high-risk medical personnel towards severe acute respiratory syndrome and their psychological characteristics. Chin J Clin Rehab. 2005;9(4):77-9.

6. $\quad \mathrm{Li} X \mathrm{~L}$, Li XL, Zhang $\mathrm{Q}$. An investigation of response to SARS stress and mental health of nurse students during SARS prevalent period. Chin J Clin Rehab. 2005;9(44):165-7.

7. Xuehua L, Li M, Fangiang M. Psychological Stress of Nurses in SARS Wards. Chinese Mental Health Journal. 2003;17(8):526-7.

8. Xu Y, Zhang KR, Yang H. Difference of posttraumatic stress disorder between severe acute respiratory syndrome patients and the public in epidemic area. Chin J Clin Rehab. 2005;9(16):214-5.

* Excluded due to full text not available (we did not contact authors due to time constraints)

1. Sun $\mathrm{H}$, Ren X. Psychological analysis for the medical staff suffering from severe acute respiratory syndrome. Chin J Clin Rehab. 2004;8(33):7609-11.

2. Hurley PM. Human immunodeficiency virus and mental health: meeting the needs of health professionals. Archives of psychiatric nursing. 1989;3(5):277-80.

3. Zuo Q, Xi ZM, Chen SY, Wang YL, Ma LX, Fan JS, et al. Comparison of anxious level of medical students from different resources during severe acute respiratory syndrome epidemic period. Chin J Clin Rehab. 2005;9(4):32-3.

4. Shi C, Yu X, Hong N, Chan RCK, Chen Y, He Y. Emotional, memory and daily function among health care worker survivors with SARS. Chinese Mental Health Journal.

2011;25(9):660-5. 
medRxiv preprint doi: https://doi.org/10.1101/2020.04.02.20048892; this version posted April 6, 2020. The copyright holder for this preprint (which was not certified by peer review) is the author/funder, who has granted medRxiv a license to display the preprint in perpetuity.

It is made available under a CC-BY-ND 4.0 International license .

\section{Online Appendix 3. Risk of bias assessment}

A. Risk of bias of cross-sectional, assessed with the "Risk of Bias Instrument for CrossSectional Surveys of Attitudes and Practices" (Evidence Partners)

\begin{tabular}{|c|c|c|c|c|c|c|}
\hline & 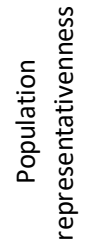 & 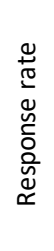 & 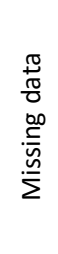 & 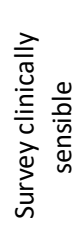 & 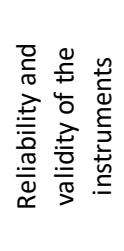 & \multirow{7}{*}{$\begin{array}{l}\text { (5) Low risk } \\
\text { (?) Some concerns } \\
\text { High risk }\end{array}$} \\
\hline Lai 2020 & (?) & $(+)$ & ? & $(+)$ & (?) & \\
\hline Li 2020 & (3) & (?) & (?) & $(+1)$ & (4) & \\
\hline Xiao 2020 & $(+)$ & (4) & (4) & $(+)$ & (4) & \\
\hline Alsubaie 2019 & (?) & () & + & (3) & ? ? & \\
\hline Schreiber 2019 & 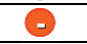 & $(+)$ & ? & (?) & 8 & \\
\hline Park 2018 & $\theta$ & (?) & (?) & (?) & $(+)$ & \\
\hline Oh 2017 & (?) & $(+)$ & $(+)$ & (3) & $(4)$ & \\
\hline Tang 2017 & (-) & (?) & +4 & (?) & $(5)$ & \\
\hline Bukhari 2016 & (?) & (4) & ? & +5 & (4) & \\
\hline Khalid 2016 & (-) & $(+)$ & $(+)$ & + & $(+)$ & \\
\hline Kim 2016 & $(+)$ & (4) & + & $(+)$ & $(+)$ & \\
\hline Lehmann 2016 & (2) & (?) & ? ? & (). & () & \\
\hline Li 2015 & (?) & (?) & $(+)$ & $(+)$ & $(+)$ & \\
\hline Liu 2012 & ? ? & (4) & (i) & (4) & (i) & \\
\hline \begin{tabular}{|l|} 
Matsuishi 2012 \\
\end{tabular} & ? ? & (3) & +1 & + & + & \\
\hline Aiello 2011 & (?) & (i) & (?) & (-) & 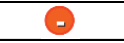 & \\
\hline Austria Corrales 2011 & (?) & (1) & (5) & ? & $(+)$ & \\
\hline Goulia 2010 & (?) & (3) & ? ? & ? ? & (?) & \\
\hline Imai 2010 & (4) & (†) & (-) & 5 & () & \\
\hline Lancee 2008 & (4) & (3) & (?) & (†) & (4) & \\
\hline Styra 2008 & $(4)$ & (?) & (?) & (4) & $(+5)$ & \\
\hline Wu 2008 & $(4)$ & (4) & $(+)$ & $(4)$ & $(4)$ & \\
\hline Chen 2007 & $(+)$ & (3) & (?) & $(+)$ & $(+)$ & \\
\hline Lin 2007 & 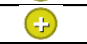 & $(+)$ & $(+)$ & + & $(+)$ & \\
\hline Marjanovic 2007 & (3) & (3) & ? ? & 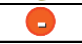 & $(+)$ & \\
\hline Wong 2007 & (4) & (?) & (?) & (?) & (5) & \\
\hline Fiksenbaum 2006 & (?) & (?) & $(+)$ & (-) & $(+)$ & \\
\hline Loh 2006 & (?) & (4) & $(+)$ & (?) & (-) & \\
\hline Lu 2006 & + & (ㄷ) & $(+5)$ & 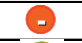 & (4) & \\
\hline Maunder 2006 & $(+)$ & (4) & (?) & $\rightarrow$ & $(4)$ & \\
\hline Grace 2005 & $\rightarrow$ & (?) & (?) & (?) & (-) & \\
\hline Ho 2005 & (3) & (?) & (1) & $(+)$ & + & \\
\hline Koh 2005 & (-) & $(+)$ & ? & $(+)$ & $(9)$ & \\
\hline Lee 2005 & $(+)$ & (4) & (?) & (?) & (?) & \\
\hline Phua 2005 & (?) & (5) & ? & (1) & (5) & \\
\hline Tham 2005 & (?) & (1) & (?) & $(+)$ & (-) & \\
\hline Tolomiczenko 2005 & ( & ( & (3) & 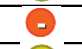 & ( & \\
\hline Wong 2005 & ? ? & (?) & (?) & + & (?) & \\
\hline Bai 2004 & (3) & (4). & (?) & ? ? & + & \\
\hline Chan 2004 & (?) & $(+)$ & ?? & $+(+)$ & + & \\
\hline Chong 2004 & $(+)$ & (4) & $(+)$ & $(+)$ & $(4)$ & \\
\hline Chua 2004 & $(+)$ & + & $(+)$ & $(+)$ & $(+)$ & \\
\hline Khee 2004 & (?) & (?) & (?) & (-) & () & \\
\hline Maunder 2004 & (3) & $(-)$ & $(+)$ & + & $(+)$ & \\
\hline Nickell 2004 & $(4)$ & (?) & ? & $(+)$ & (4) & \\
\hline Poon 2004 & (3) & (3) & $(+)$ & $(+)$ & (1) & \\
\hline Sim 2004 & (4) & (4) & (?) & (4) & + & \\
\hline Tam 2004 & $(+)$ & (-) & (3) & $(+)$ & (3) & \\
\hline Verma 2004 & $(+)$ & 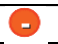 & $(+)$ & $(+)$ & $(+)$ & \\
\hline Wong 2004 & (3) & $(+5)$ & +9 & (-) & (-) & \\
\hline
\end{tabular}




\section{B. Risk of bias of uncontrolled before-after studies (assess with ROBINS - I)}

\begin{tabular}{|c|c|c|c|c|c|c|c|c|c|c|c|c|c|c|c|}
\hline & \multicolumn{2}{|c|}{$\begin{array}{l}\text { Bias due to } \\
\text { confounding }\end{array}$} & \multicolumn{2}{|c|}{$\begin{array}{l}\text { Bias in selection of participants } \\
\text { into the study }\end{array}$} & \multicolumn{2}{|c|}{$\begin{array}{l}\text { Bias in classification of } \\
\text { interventions }\end{array}$} & \multicolumn{2}{|c|}{$\begin{array}{l}\text { Bias due to deviations } \\
\text { from intended } \\
\text { interventions }\end{array}$} & \multicolumn{2}{|c|}{$\begin{array}{l}\text { Bias due to missing } \\
\text { data }\end{array}$} & \multicolumn{2}{|c|}{$\begin{array}{l}\text { Bias in } \\
\text { measurement of } \\
\text { outcomes }\end{array}$} & \multicolumn{2}{|c|}{$\begin{array}{l}\text { Bias in selection of } \\
\text { the reported result }\end{array}$} & \multirow[t]{2}{*}{$\begin{array}{l}\text { Overal } \\
\text { I bias }\end{array}$} \\
\hline & $\begin{array}{l}\text { Ratin } \\
\text { g }\end{array}$ & Comments & Rating & Comments & Rating & Comments & Rating & Comments & Rating & Comments & Rating & $\begin{array}{l}\text { Comment } \\
\mathrm{s}\end{array}$ & Rating & $\begin{array}{l}\text { Comment } \\
\mathrm{s}\end{array}$ & \\
\hline $\begin{array}{l}\text { Chen } \\
2006\end{array}$ & Low & $\begin{array}{l}\text { GEE } \\
\text { analysis for } \\
\text { confoundin } \\
\text { g factors } \\
\text { and time- } \\
\text { varying } \\
\text { analysis. } \\
\text { The } \\
\text { negative } \\
\text { side is the } \\
\text { factors } \\
\text { were self- } \\
\text { reported. }\end{array}$ & $\begin{array}{l}\text { Seriou } \\
\mathrm{s}\end{array}$ & $\begin{array}{l}\text { Nurses volunteered } \\
\text { to participate in the } \\
\text { study (participation } \\
\text { probably related to } \\
\text { intervention/outcom } \\
\text { e). No preliminary } \\
\text { analysis or } \\
\text { assessment. }\end{array}$ & $\begin{array}{l}\text { Moderat } \\
\text { e }\end{array}$ & $\begin{array}{l}\text { (i) } \\
\text { Intervention } \\
\text { status is well } \\
\text { defined; and } \\
\text { (ii) Some } \\
\text { aspects of } \\
\text { the } \\
\text { assignments } \\
\text { of } \\
\text { intervention } \\
\text { status were } \\
\text { determined } \\
\text { retrospective } \\
\text { ly } \\
\text { (participation } \\
\text { was } \\
\text { voluntary } \\
\text { and } \\
\text { knowledge of } \\
\text { the } \\
\text { prevention } \\
\text { program may } \\
\text { have affected } \\
\text { the } \\
\text { intervention) }\end{array}$ & $\begin{array}{l}\text { No } \\
\text { informatio } \\
n\end{array}$ & $\begin{array}{l}\text { Not } \\
\text { applicable. } \\
\text { It is not } \\
\text { possible to } \\
\text { observe } \\
\text { any } \\
\text { differences } \\
\text { from the } \\
\text { intended } \\
\text { interventio } \\
\text { n. }\end{array}$ & Low & - & $\begin{array}{l}\text { Seriou } \\
\mathrm{s}\end{array}$ & $\begin{array}{l}\text { Subjectiv } \\
\mathrm{e} \\
\text { measures } \\
\text {. Team } \\
\text { was } \\
\text { aware of } \\
\text { allocation } \\
\text { status. }\end{array}$ & $\begin{array}{l}\text { Moderat } \\
\text { e }\end{array}$ & $\begin{array}{l}\text { GEE } \\
\text { analysis is } \\
\text { presente } \\
d \text { later in } \\
\text { the } \\
\text { results, } \\
\text { not in the } \\
\text { methods. }\end{array}$ & $\begin{array}{l}\text { Seriou } \\
\mathrm{s}\end{array}$ \\
\hline $\begin{array}{l}\text { Maunde } \\
\text { r } 2010\end{array}$ & $\begin{array}{l}\text { Critic } \\
\text { al }\end{array}$ & $\begin{array}{l}\text { No } \\
\text { adjusted } \\
\text { analysis of } \\
\text { confoundin } \\
\text { g factors }\end{array}$ & $\begin{array}{l}\text { Seriou } \\
\mathrm{s}\end{array}$ & & $\begin{array}{l}\text { Moderat } \\
\text { e }\end{array}$ & $\begin{array}{l}\text { (i) } \\
\text { Intervention } \\
\text { status is well } \\
\text { defined; and } \\
\text { (ii) Some } \\
\text { aspects of } \\
\text { the } \\
\text { assignments } \\
\text { of } \\
\text { intervention }\end{array}$ & $\begin{array}{l}\text { No } \\
\text { informatio } \\
n\end{array}$ & $\begin{array}{l}\text { Not } \\
\text { applicable. } \\
\text { It is not } \\
\text { possible to } \\
\text { observe } \\
\text { any } \\
\text { differences } \\
\text { from the } \\
\text { intended }\end{array}$ & $\begin{array}{l}\text { Seriou } \\
\mathrm{s}\end{array}$ & $\begin{array}{l}\text { Proportions } \\
\text { of missing } \\
\text { participants } \\
\text { differ } \\
\text { substantially } \\
\text { across } \\
\text { intervention } \\
\text { s: Attrition } \\
\text { was } 12 \% \text { in } \\
\text { short }\end{array}$ & $\begin{array}{l}\text { Seriou } \\
\mathrm{s}\end{array}$ & $\begin{array}{l}\text { Subjectiv } \\
\mathrm{e} \\
\text { measures } \\
\text {. Team } \\
\text { was } \\
\text { aware of } \\
\text { allocation } \\
\text { status. }\end{array}$ & Low & $\begin{array}{l}\text { All } \\
\text { outcomes } \\
\text { listed in } \\
\text { the } \\
\text { methods } \\
\text { are also } \\
\text { reported } \\
\text { in the } \\
\text { results. } \\
\text { Do not }\end{array}$ & $\begin{array}{l}\text { Critica } \\
\text { I }\end{array}$ \\
\hline
\end{tabular}




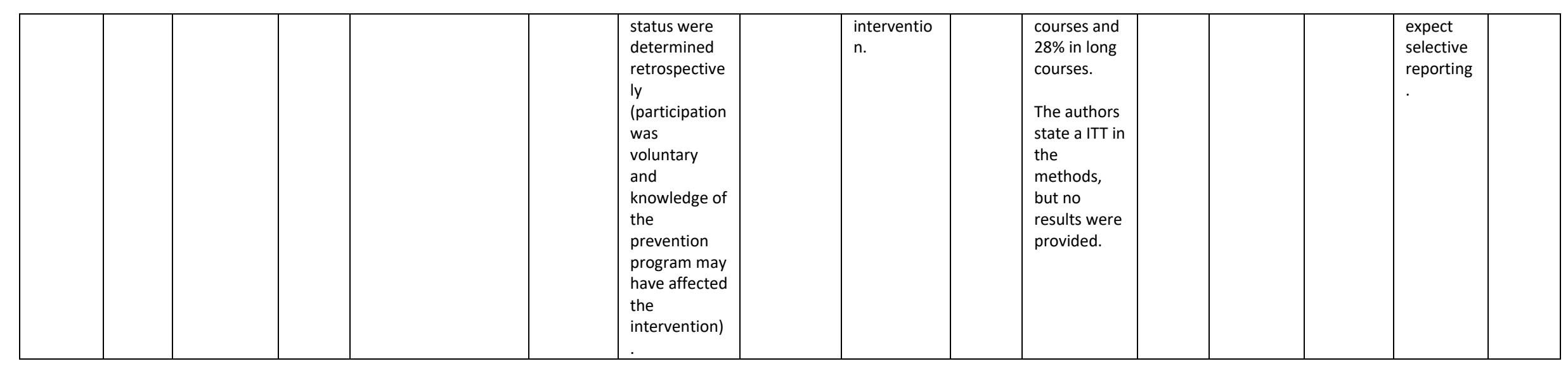




\section{Risk of bias of the systematic review identified (Brooks 2018), assessed with AMSTAR.}

\begin{tabular}{|c|c|c|}
\hline & & Brooks 2018 \\
\hline & PICO question & (5) \\
\hline & Following the protocol and methodology & ( \\
\hline & Selection of the study designs for inclusion & (1) \\
\hline & Comprehensive literature search strategy & (1) \\
\hline & Study selection in duplicate performed & \\
\hline & Data extraction in duplicate performed & ( \\
\hline & List of excluded studies and justification provided & 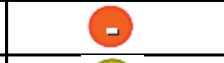 \\
\hline & Included studies described in detail & $(15)$ \\
\hline & Risk of bias (RoB) assessed & (1) \\
\hline & Sources of funding reported & 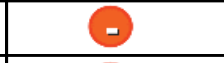 \\
\hline & Meta-analysis performed with appropriate statistical combination of results & 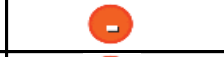 \\
\hline & Potential impact of RoB in individual studies & 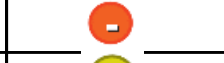 \\
\hline & RoB idiscussed in the results & (1) \\
\hline & Discussion of any heterogeneity & $(+)$ \\
\hline & Investigation and discussion of publication bias & $(-)$ \\
\hline & Conflict of interest reported & $(+)$ \\
\hline
\end{tabular}


D. Risk of bias of cohort studies, assessed with the "Tool to Assess Risk of Bias in Cohort Studies" (Evidence Partners)

\begin{tabular}{|c|c|c|c|c|c|c|c|c|c|}
\hline & 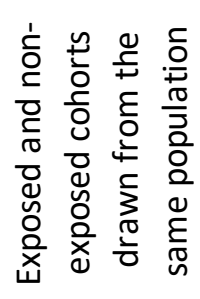 & 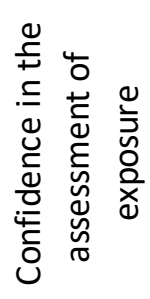 & 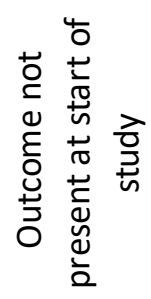 & 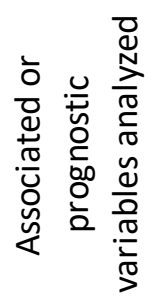 & 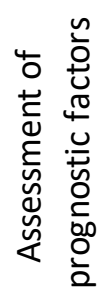 & 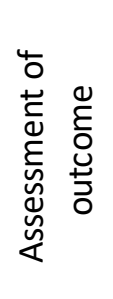 & 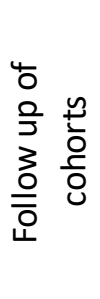 & 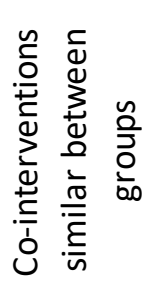 & \multirow{7}{*}{$\begin{array}{l}\text { (+) Low risk } \\
\text { (?) Some concerns } \\
\text { High risk }\end{array}$} \\
\hline Lee 2018 & $\theta$ & $(+5)$ & (?) & +1 & +1 & (?) & (?) & (?) & \\
\hline Lung 2009 & (4) & + & (-) & $(+)$ & $(5)$ & $(5)$ & (3) & (?) & \\
\hline Wu 2009 & (?) & + & $(+)$ & $(+)$ & $(+)$ & + & +5 & (3) & \\
\hline Lee 2007 & $(+)$ & $(5)$ & (?) & 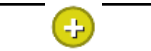 & $(+)$ & + & (?) & (?) & \\
\hline McAlonan 2007 & $(+)$ & (i) & (?) & $(+)$ & (?) & $(5)$ & (3) & (3) & \\
\hline Su 2007 & (i) & + & (-) & $(+)$ & + & +5 & (1) & (4) & \\
\hline
\end{tabular}

E. Risk of bias of case control studies, assessed with the "Tool to Assess Risk of Bias in Case Control Studies" (Evidence Partners)

\begin{tabular}{|r|r|}
\hline Confidence in the assessment of exposure & Chen 2005 \\
\hline Cases develope the outcome but not controls & \\
\hline Cases selection & $?$ \\
\hline Controls selection & $?$ \\
\hline
\end{tabular}


medRxiv preprint doi: https://doi.org/10.1101/2020.04.02.20048892; this version posted April 6, 2020. The copyright holder for this preprint (which was not certified by peer review) is the author/funder, who has granted medRxiv a license to display the preprint in perpetuity. It is made available under a CC-BY-ND 4.0 International license .

\section{REFERENCES}

1. Aiello A, Khayeri MY-E, Raja S, Peladeau N, Romano D, Leszcz M, et al. Resilience training for hospital workers in anticipation of an influenza pandemic. The Journal of continuing education in the health professions. 2011;31(1):15-20.

2. Alsubaie S, Hani Temsah M, Al-Eyadhy AA, Gossady I, Hasan GM, Al-Rabiaah A, et al. Middle East Respiratory Syndrome Coronavirus epidemic impact on healthcare workers' risk perceptions, work and personal lives. Journal of infection in developing countries. 2019;13(10):920-6.

3. Austria-Corrales F, Cruz-Valdes B, Herrera-Kiengelher L, Vazquez-Garcia JC, SalasHernandez J. [Burnout syndrome among medical residents during the influenza A H1N1 sanitary contigency in Mexico]. Sindrome de burnout en medicos mexicanos en entrenamiento durante una contingencia sanitaria por virus de influenza A H1N1. 2011;147(2):97-103.

4. Bai Y, Lin C-C, Lin C-Y, Chen J-Y, Chue C-M, Chou P. Survey of stress reactions among health care workers involved with the SARS outbreak. Psychiatric services (Washington, DC). 2004;55(9):1055-7.

5. Brooks SK, Dunn R, Amlot R, Rubin GJ, Greenberg N. A Systematic, Thematic Review of Social and Occupational Factors Associated With Psychological Outcomes in Healthcare Employees During an Infectious Disease Outbreak. Journal of occupational and environmental medicine. 2018;60(3):248-57.

6. Bukhari EE, Temsah MH, Aleyadhy AA, Alrabiaa AA, Alhboob AA, Jamal AA, et al. Middle East respiratory syndrome coronavirus (MERS-CoV) outbreak perceptions of risk and stress evaluation in nurses. Journal of infection in developing countries. 2016;10(8):845-50.

7. Chan AOM, Huak CY. Psychological impact of the 2003 severe acute respiratory syndrome outbreak on health care workers in a medium size regional general hospital in Singapore. Occupational medicine (Oxford, England). 2004;54(3):190-6.

8. Chan SS, Leung GM, Tiwari AF, Salili F, Leung SS, Wong DC, et al. The impact of workrelated risk on nurses during the SARS outbreak in Hong Kong. Family \& community health. 2005;28(3):274-87.

9. Chen C-S, Wu H-Y, Yang P, Yen C-F. Psychological Distress of Nurses in Taiwan Who Worked During the Outbreak of SARS. Psychiatric Services. 2005;56(1):76-9.

10. Chen N-H, Wang P-C, Hsieh M-J, Huang C-C, Kao K-C, Chen $\mathrm{Y}-\mathrm{H}$, et al. Impact of severe acute respiratory syndrome care on the general health status of healthcare workers in taiwan. Infection control and hospital epidemiology. 2007;28(1):75-9.

11. Chen R, Chou K-R, Huang Y-J, Wang T-S, Liu S-Y, Ho L-Y. Effects of a SARS prevention programme in Taiwan on nursing staff's anxiety, depression and sleep quality: a longitudinal survey. International journal of nursing studies. 2006;43(2):215-25.

12. Chong M-Y, Wang W-C, Hsieh W-C, Lee C-Y, Chiu N-M, Yeh W-C, et al. Psychological impact of severe acute respiratory syndrome on health workers in a tertiary hospital. The British journal of psychiatry : the journal of mental science. 2004;185(342367):127-33.

13. Chua SE, Cheung V, Cheung C, McAlonan GM, Wong JWS, Cheung EPT, et al. Psychological effects of the SARS outbreak in Hong Kong on high-risk health care workers. Canadian journal of psychiatry Revue canadienne de psychiatrie. 2004;49(6):391-3. 
medRxiv preprint doi: https://doi.org/10.1101/2020.04.02.20048892; this version posted April 6, 2020. The copyright holder for this preprint (which was not certified by peer review) is the author/funder, who has granted medRxiv a license to display the preprint in perpetuity. It is made available under a CC-BY-ND 4.0 International license .

14. Goulia P, Mantas C, Dimitroula D, Mantis D, Hyphantis T. General hospital staff worries, perceived sufficiency of information and associated psychological distress during the $A / H 1 N 1$ influenza pandemic. BMC infectious diseases. 2010;10(100968551):322.

15. Grace SL, Hershenfield K, Robertson E, Stewart DE. The occupational and psychosocial impact of SARS on academic physicians in three affected hospitals. Psychosomatics. 2005;46(5):385-91.

16. Ho SMY, Kwong-Lo RSY, Mak CWY, Wong JS. Fear of severe acute respiratory syndrome (SARS) among health care workers. Journal of consulting and clinical psychology. 2005;73(2):344-9.

17. Ji D, Ji Y-J, Duan X-Z, Li W-G, Sun Z-Q, Song X-A, et al. Prevalence of psychological symptoms among Ebola survivors and healthcare workers during the 2014-2015 Ebola outbreak in Sierra Leone: a cross-sectional study. Oncotarget. 2017;8(8):12784-91.

18. KS Khee, LB Lee, OT Chai, CK Loong. The psychological impact of SARS on health care providers. Crit Care Shock. 2004;7(2):99-106.

19. KY Tham, YH Tan, OH Loh, WL Tan. Psychological morbidity among emergency department doctors and nurses after the SARS outbreak. Hong Kong J Emerg Med. 2005;12(4):215-23.

20. Khalid I, Khalid TJ, Qabajah MR, Barnard AG, Qushmaq IA. Healthcare Workers Emotions, Perceived Stressors and Coping Strategies During a MERS-CoV Outbreak. Clinical medicine \& research. 2016;14(1):7-14.

21. Kim JS, Choi JS. Factors Influencing Emergency Nurses' Burnout During an Outbreak of Middle East Respiratory Syndrome Coronavirus in Korea. Asian nursing research. 2016;10(4):295-9.

22. Koh D, Lim MK, Chia SE, Ko SM, Qian F, Ng V, et al. Risk Perception and Impact of Severe Acute Respiratory Syndrome (SARS) on Work and Personal Lives of Healthcare Workers in Singapore: What Can We Learn? Medical Care. 2005;43(7):676-82.

23. L Fiksenbaum, Z Marjanovic, ER Greenglass. Emotional exhaustion and state anger in nurses who worked during the sars outbreak: The role of perceived threat and organizational support. Can J Community Ment Health. 2006;25(2):89-103.

24. Lai J, Ma S, Wang Y, Cai Z, Hu J, Wei N, et al. Factors Associated With Mental Health Outcomes Among Health Care Workers Exposed to Coronavirus Disease 2019. JAMA Network Open. 2020;3(3):e203976-e.

25. Lancee WJ, Maunder RG, Goldbloom DS. Prevalence of psychiatric disorders among Toronto hospital workers one to two years after the SARS outbreak. Psychiatric Services. 2008;59(1):91-5.

26. Lee AM, Wong JGWS, McAlonan GM, Cheung V, Cheung C, Sham PC, et al. Stress and psychological distress among SARS survivors 1 year after the outbreak. Canadian journal of psychiatry Revue canadienne de psychiatrie. 2007;52(4):233-40.

27. Lee $\mathrm{S}-\mathrm{H}$, Juang $\mathrm{Y}-\mathrm{Y}$, Su Y-J, Lee $\mathrm{H}-\mathrm{L}$, Lin $\mathrm{Y}-\mathrm{H}$, Chao C-C. Facing SARS: psychological impacts on SARS team nurses and psychiatric services in a Taiwan general hospital. General hospital psychiatry. 2005;27(5):352-8.

28. Lee SM, Kang WS, Cho A-R, Kim T, Park JK. Psychological impact of the 2015 MERS outbreak on hospital workers and quarantined hemodialysis patients. Comprehensive psychiatry. 2018;87:123-7. 
medRxiv preprint doi: https://doi.org/10.1101/2020.04.02.20048892; this version posted April 6, 2020. The copyright holder for this preprint (which was not certified by peer review) is the author/funder, who has granted medRxiv a license to display the preprint in perpetuity. It is made available under a CC-BY-ND 4.0 International license .

29. Lehmann M, Bruenahl CA, Addo MM, Becker S, Schmiedel S, Lohse AW, et al. Acute Ebola virus disease patient treatment and health-related quality of life in health care professionals: A controlled study. Journal of psychosomatic research. 2016;83(376333):69-74.

30. Li L, Wan C, Ding R, Liu Y, Chen J, Wu Z, et al. Mental distress among Liberian medical staff working at the China Ebola Treatment Unit: a cross sectional study. Health and quality of life outcomes. 2015;13(101153626):156.

31. Li Z, Ge J, Yang M, Feng J, Qiao M, Jiang R, et al. Vicarious traumatization in the general public, members, and non-members of medical teams aiding in COVID-19 control. Brain, behavior, and immunity. 2020.

32. Lin C-Y, Peng Y-C, Wu Y-H, Chang J, Chan C-H, Yang D-Y. The psychological effect of severe acute respiratory syndrome on emergency department staff. Emergency medicine journal : EMJ. 2007;24(1):12-7.

33. Liu X, Kakade M, Fuller CJ, Fan B, Fang Y, Kong J, et al. Depression after exposure to stressful events: lessons learned from the severe acute respiratory syndrome epidemic. Comprehensive psychiatry. 2012;53(1):15-23.

34. Loh L-C, Ali AM, Ang T-H, Chelliah A. Impact of a spreading epidemic on medical students. The Malaysian journal of medical sciences : MJMS. 2006;13(2):30-6.

35. Lu Y-C, Shu B-C, Chang Y-Y, Lung F-W. The mental health of hospital workers dealing with severe acute respiratory syndrome. Psychotherapy and psychosomatics. 2006;75(6):370-5.

36. Lung F-W, Lu Y-C, Chang Y-Y, Shu B-C. Mental Symptoms in Different Health Professionals During the SARS Attack: A Follow-up Study. The Psychiatric quarterly. 2009;80(2):107-16.

37. Marjanovic Z, Greenglass ER, Coffey S. The relevance of psychosocial variables and working conditions in predicting nurses' coping strategies during the SARS crisis: an online questionnaire survey. International journal of nursing studies. 2007;44(6):991-8.

38. Matsuishi K, Kawazoe A, Imai H, Ito A, Mouri K, Kitamura N, et al. Psychological impact of the pandemic (H1N1) 2009 on general hospital workers in Kobe. Psychiatry and clinical neurosciences. 2012;66(4):353-60.

39. Maunder RG, Lancee WJ, Balderson KE, Bennett JP, Borgundvaag B, Evans S, et al. Longterm psychological and occupational effects of providing hospital healthcare during SARS outbreak. Emerging infectious diseases. 2006;12(12):1924-32.

40. Maunder RG, Lancee WJ, Mae R, Vincent L, Peladeau N, Beduz MA, et al. Computerassisted resilience training to prepare healthcare workers for pandemic influenza: a randomized trial of the optimal dose of training. BMC health services research. 2010;10(101088677):72.

41. Maunder RG, Lancee WJ, Rourke S, Hunter JJ, Goldbloom D, Balderson K, et al. Factors associated with the psychological impact of severe acute respiratory syndrome on nurses and other hospital workers in Toronto. Psychosomatic medicine. 2004;66(6):938-42.

42. McAlonan GM, Lee AM, Cheung V, Cheung C, Tsang KWT, Sham PC, et al. Immediate and sustained psychological impact of an emerging infectious disease outbreak on health care workers. Canadian journal of psychiatry Revue canadienne de psychiatrie. 2007;52(4):241-7.

43. Nickell LA, Crighton EJ, Tracy CS, Al-Enazy H, Bolaji Y, Hanjrah S, et al. Psychosocial effects of SARS on hospital staff: survey of a large tertiary care institution. CMAJ : Canadian Medical Association journal = journal de l'Association medicale canadienne. 2004;170(5):793-8. 
medRxiv preprint doi: https://doi.org/10.1101/2020.04.02.20048892; this version posted April 6, 2020. The copyright holder for this preprint (which was not certified by peer review) is the author/funder, who has granted medRxiv a license to display the preprint in perpetuity. It is made available under a CC-BY-ND 4.0 International license .

44. Oh N, Hong N, Ryu DH, Bae SG, Kam S, Kim K-Y. Exploring Nursing Intention, Stress, and Professionalism in Response to Infectious Disease Emergencies: The Experience of Local Public Hospital Nurses During the 2015 MERS Outbreak in South Korea. Asian nursing research. 2017;11(3):230-6.

45. Park J-S, Lee E-H, Park N-R, Choi YH. Mental Health of Nurses Working at a Governmentdesignated Hospital During a MERS-CoV Outbreak: A Cross-sectional Study. Archives of psychiatric nursing. 2018;32(1):2-6.

46. Phua DH, Tang HK, Tham KY. Coping responses of emergency physicians and nurses to the 2003 severe acute respiratory syndrome outbreak. Academic emergency medicine : official journal of the Society for Academic Emergency Medicine. 2005;12(4):322-8.

47. Poon E, Liu KS, Cheong DL, Lee CK, Yam LYC, Tang WN. Impact of severe respiratory syndrome on anxiety levels of front-line health care workers. Hong Kong medical journal = Xianggang yi xue za zhi. 2004;10(5):325-30.

48. Schreiber M, Cates DS, Formanski S, King M. Maximizing the Resilience of Healthcare Workers in Multi-hazard Events: Lessons from the 2014-2015 Ebola Response in Africa. Military medicine. 2019;184:114-20.

49. Sim K, Chong PN, Chan YH, Soon WSW. Severe acute respiratory syndrome-related psychiatric and posttraumatic morbidities and coping responses in medical staff within a primary health care setting in Singapore. The Journal of clinical psychiatry. 2004;65(8):1120-7.

50. Styra R, Hawryluck L, Robinson S, Kasapinovic S, Fones C, Gold WL. Impact on health care workers employed in high-risk areas during the Toronto SARS outbreak. Journal of psychosomatic research. 2008;64(2):177-83.

51. Su T-P, Lien T-C, Yang C-Y, Su YL, Wang J-H, Tsai S-L, et al. Prevalence of psychiatric morbidity and psychological adaptation of the nurses in a structured SARS caring unit during outbreak: a prospective and periodic assessment study in Taiwan. Journal of psychiatric research. 2007;41(1):119-30.

52. Tam CWC, Pang EPF, Lam LCW, Chiu HFK. Severe acute respiratory syndrome (SARS) in Hong Kong in 2003: stress and psychological impact among frontline healthcare workers. Psychological medicine. 2004;34(7):1197-204.

53. Tang L, Pan L, Yuan L, Zha L. Prevalence and related factors of post-traumatic stress disorder among medical staff members exposed to H7N9 patients. International journal of nursing sciences. 2017;4(1):63-7.

54. Tolomiczenko GS, Kahan M, Ricci M, Strathern L, Jeney C, Patterson K, et al. SARS: coping with the impact at a community hospital. Journal of advanced nursing. 2005;50(1):101-10.

55. Verma S, Mythily S, Chan YH, Deslypere JP, Teo EK, Chong SA. Post-SARS psychological morbidity and stigma among general practitioners and traditional Chinese medicine practitioners in Singapore. Annals of the Academy of Medicine, Singapore. 2004;33(6):743-8.

56. Wong TW, Yau JKY, Chan CLW, Kwong RSY, Ho SMY, Lau CC, et al. The psychological impact of severe acute respiratory syndrome outbreak on healthcare workers in emergency departments and how they cope. European journal of emergency medicine : official journal of the European Society for Emergency Medicine. 2005;12(1):13-8.

57. Wong WC, Wong SY, Lee A, Goggins WB. How to provide an effective primary health care in fighting against severe acute respiratory syndrome: the experiences of two cities. American journal of infection control. 2007;35(1):50-5. 
medRxiv preprint doi: https://doi.org/10.1101/2020.04.02.20048892; this version posted April 6, 2020. The copyright holder for this preprint (which was not certified by peer review) is the author/funder, who has granted medRxiv a license to display the preprint in perpetuity. It is made available under a CC-BY-ND 4.0 International license .

58. Wong WCW, Lee A, Tsang KK, Wong SYS. How did general practitioners protect themselves, their family, and staff during the SARS epidemic in Hong Kong? Journal of epidemiology and community health. 2004;58(3):180-5.

59. Wu P, Fang Y, Guan Z, Fan B, Kong J, Yao Z, et al. The psychological impact of the SARS epidemic on hospital employees in China: Exposure, risk perception, and altruistic acceptance of risk. The Canadian Journal of Psychiatry / La Revue canadienne de psychiatrie. 2009;54(5):302-11.

60. Wu P, Liu X, Fang Y, Fan B, Fuller CJ, Guan Z, et al. Alcohol abuse/dependence symptoms among hospital employees exposed to a SARS outbreak. Alcohol and alcoholism (Oxford, Oxfordshire). 2008;43(6):706-12.

61. Xiao H, Zhang Y, Kong D, Li S, Yang N. The Effects of Social Support on Sleep Quality of Medical Staff Treating Patients with Coronavirus Disease 2019 (COVID-19) in January and February 2020 in China. Medical science monitor : international medical journal of experimental and clinical research. 2020;26:e923549. 
Online Appendix 4. Summary of Findings table of studies examining the impact on mental health problems in healthcare workers during and after viral epidemics

A. Summary of Findings table of studies examining the impact on mental health problems in healthcare workers during viral epidemics ( $N=27$ )

\begin{tabular}{|c|c|c|c|c|}
\hline $\begin{array}{l}\text { Author/ } \\
\text { year/health } \\
\text { emergency/ } \\
\text { country/ }\end{array}$ & $\begin{array}{l}\text { Setting } \\
\text { Type of healthcare } \\
\text { professionals }\end{array}$ & $\begin{array}{l}\text { Sample size } \\
\text { (N) }\end{array}$ & $\begin{array}{l}\text { Mental health problem } \\
\text { (tool) }\end{array}$ & Main results \\
\hline \multicolumn{5}{|c|}{ Cross-sectional studies } \\
\hline $\begin{array}{l}\text { Lai } 2020(1) \\
\text { COVID-19 } \\
\text { China }\end{array}$ & $\begin{array}{l}\text { Hospitals } \\
\text { HCWs }\end{array}$ & $\mathrm{N}=1,257$ & $\begin{array}{l}\text { Depression (PHQ-9), } \\
\text { anxiety (GAD-7), } \\
\text { insomnia-(7-item } \\
\text { Insomnia Severity Index), } \\
\text { distress (IES-R) }\end{array}$ & $\begin{array}{l}\text { Participants reported symptoms of depression (634 [50.4\%]), anxiety (560 } \\
[44.6 \%]) \text {, insomnia }(427[34.0 \%]) \text {, and distress }(899[71.5 \%]) \text {. Nurses, } \\
\text { women, frontline HCWs, and those working in Wuhan, China, reported } \\
\text { more severe degrees of all measurements of mental health symptoms than } \\
\text { other HCWs. Frontline HCWs engaged in direct diagnosis, treatment, and } \\
\text { care of patients with COVID-19 were associated ( } \mathrm{P}<0.05) \text { with a higher risk } \\
\text { of symptoms of depression }(\mathrm{OR}=1.52) \text {, anxiety }(\mathrm{OR}=1.57) \text {, insomnia } \\
(\mathrm{OR}=2.97) \text {, and distress }(\mathrm{OR}=1.60) \text {. }\end{array}$ \\
\hline $\begin{array}{l}\text { Li 2020(2) } \\
\text { COVID-19 } \\
\text { China }\end{array}$ & $\begin{array}{l}\text { Hospitals } \\
\text { Nurses }\end{array}$ & $N=526$ & $\begin{array}{l}\text { Vicarious traumatization } \\
\text { (Chinese version of the } \\
\text { vicarious traumatization } \\
\text { questionnaire) }\end{array}$ & $\begin{array}{l}\text { Vicarious traumatization scores for front-line nurses were significantly } \\
\text { lower than those of non-front-line nurses }(P<0.001) \text {. The vicarious } \\
\text { traumatization scores of the general public were significantly higher than } \\
\text { those of the front-line nurses }(P<0.001) \text {; however, no statistical difference } \\
\text { was observed compared to the scores of non- front-line nurses }(P>0.05) \text {. }\end{array}$ \\
\hline Xiao 2020(3) & $\begin{array}{l}\text { Several facilities: } \\
\text { departments of }\end{array}$ & $\mathrm{N}=180$ & $\begin{array}{l}\text { Anxiety (SAS), PTSD } \\
\text { (SASR), self-efficacy }\end{array}$ & $\begin{array}{l}\text { Levels of social support for medical staff were significantly associated with } \\
\text { self-efficacy and sleep quality and negatively associated with the degree of }\end{array}$ \\
\hline
\end{tabular}




\begin{tabular}{|c|c|c|c|c|}
\hline $\begin{array}{l}\text { COVID-19 } \\
\text { China }\end{array}$ & $\begin{array}{l}\text { respiratory } \\
\text { medicine, fever } \\
\text { clinics, or the ICU } \\
\text { Physicians and } \\
\text { nurses }\end{array}$ & & $\begin{array}{l}\text { (GSES), sleep quality } \\
\text { (PSQI), and social support } \\
\text { (SSRS) }\end{array}$ & $\begin{array}{l}\text { anxiety and stress. Levels of anxiety were significantly associated with the } \\
\text { levels of stress, which negatively impacted self-efficacy and sleep quality. } \\
\text { Anxiety, stress, and self-efficacy were mediating variables associated with } \\
\text { social support and sleep quality. }\end{array}$ \\
\hline $\begin{array}{l}\text { Alsubaie } 2019 \\
\text { (4) } \\
\text { MERS-CoV } \\
\text { Saudi Arabia }\end{array}$ & $\begin{array}{l}\text { Tertiary care } \\
\text { teaching hospital } \\
\text { Physicians, nurses, } \\
\text { and technicians }\end{array}$ & $\mathrm{N}=284$ & Anxiety (unclear) & $\begin{array}{l}\text { The mean anxiety score was similar for physicians and other HCWs }(3 / 5) \text {; } \\
\text { however, non-physicians expressed higher levels of anxiety toward the risk } \\
\text { of transmitting MERS-CoV to their families, with an anxiety mean score of } \\
4 / 5 \text {. }\end{array}$ \\
\hline $\begin{array}{l}\text { Bukhari 2016(5) } \\
\text { MERS-Cov } \\
\text { Saudi Arabia }\end{array}$ & $\begin{array}{l}\text { Hospital } \\
\text { Medical staff } \\
\text { (HCWs and } \\
\text { administrative } \\
\text { personnel) }\end{array}$ & $\mathrm{N}=386$ & $\begin{array}{l}\text { Perception of exposure to } \\
\text { SARS, perceived risk of } \\
\text { infection, and impact of } \\
\text { the SARS outbreak on } \\
\text { personal and work life ( } 88 \\
\text { questions comprising } \\
\text { single choice, multiple } \\
\text { choice, and open-ended } \\
\text { question) and intrusion } \\
\text { and avoidance (IES) }\end{array}$ & $\begin{array}{l}\text { Significant difference in the "worry and fear" scale of contracting the } \\
\text { MERS-CoV infection between participants who worked in isolation areas, } \\
\text { ICUs, and emergency rooms (mean: } 3.01 \pm 1.1 \text { ) compared to participants } \\
\text { who worked in areas that are less likely to admit and have MERS-CoV } \\
\text { suspected or positive cases (mean: } 2.77 \pm 1.1 ; P=0.031 \text { ). Females were } \\
\text { significantly more worried and fearful of contracting the virus compared to } \\
\text { males (mean: } 2.92 \pm 1.1 \text { versus } 2.61 \pm 1.0 \text {, respectively; } P=0.045 \text { ). }\end{array}$ \\
\hline Khalid 2016(6) & $\begin{array}{l}\text { Tertiary care } \\
\text { hospital }\end{array}$ & $\mathrm{N}=117$ & $\begin{array}{l}\text { Emotions, perceived } \\
\text { stressors, factors that } \\
\text { reduced their stress, }\end{array}$ & $\begin{array}{l}\text { The main sentiments centered upon fear of personal safety and well-being } \\
\text { of colleagues and family. Positive attitudes in the workplace, clinical } \\
\text { improvement of infected colleagues, and stoppage of disease transmission }\end{array}$ \\
\hline
\end{tabular}




\begin{tabular}{|c|c|c|c|c|}
\hline $\begin{array}{l}\text { MERS-CoV } \\
\text { Saudi Arabia }\end{array}$ & HCWs & & $\begin{array}{l}\text { coping strategies, and } \\
\text { motivators to work } \\
\text { during future outbreaks } \\
\text { (MERS-CoV staff } \\
\text { questionnaire) }\end{array}$ & $\begin{array}{l}\text { among HCWs after adopting strict protective measures alleviated their fear } \\
\text { and drove them through the epidemic. HCWs appreciated recognition of } \\
\text { their efforts by hospital management and expected similar } \\
\text { acknowledgment, infection control guidance, and equipment would entice } \\
\text { them to work during future epidemics. }\end{array}$ \\
\hline $\begin{array}{l}\text { Kim 2016(7) } \\
\text { MERS-CoV } \\
\text { South Korea }\end{array}$ & $\begin{array}{l}\text { Hospitals } \\
\text { designated for } \\
\text { treating MERS- } \\
\text { CoV-infected } \\
\text { patients } \\
\text { Emergency } \\
\text { department nurses }\end{array}$ & $\mathrm{N}=215$ & $\begin{array}{l}\text { Burnout (OLBI), stress } \\
\text { (Parker and DeCotiis } \\
\text { scale) }\end{array}$ & $\begin{array}{l}\text { The emergency department nurses' burnout was affected by job stress } \\
(\beta=0.59, P<0.001) \text {, poor hospital resources for the treatment of MERS-CoV } \\
(\beta=0.19, P<0.001) \text { and poor support from family and friends } \beta=0.14, P< \\
0.05) \text {. These three variables explained } 47.3 \% \text { of the variance in burnout. }\end{array}$ \\
\hline $\begin{array}{l}\text { Li 2015(8) } \\
\text { Ebola } \\
\text { Liberia }\end{array}$ & $\begin{array}{l}\text { China Ebola } \\
\text { Treatment Unit } \\
\text { HCWs }\end{array}$ & $N=52$ & $\begin{array}{l}\text { General psychological } \\
\text { status (SCL-90-R) }\end{array}$ & $\begin{array}{l}\text { Mean General Severity Index, Positive Symptom Total and Positive } \\
\text { Symptom Distress Index was } 0.42 \pm 0.42,24.15 \pm 18.27 \text {, and } 1.31 \pm 0.51 \text {, } \\
\text { respectively. Mental distress among participants was not very serious; only } \\
\text { Positive Symptom Distress Index paranoid ideation and interpersonal } \\
\text { sensitivity numerically increased relative to changes in other categories. } \\
\text { While male physicians and those responsible for cleaning and disinfection } \\
\text { showed significant increases in scores for psychological dimensions, such } \\
\text { as obsessive-compulsive, anxiety, phobic anxiety, interpersonal sensitivity, } \\
\text { paranoid ideation and positive symptom total. }\end{array}$ \\
\hline $\begin{array}{l}\text { Austria Corrales } \\
2011(9)\end{array}$ & Hospital & $\mathrm{N}=99$ & Burnout (MBIQ) & $\begin{array}{l}36 \text { medical residents ( } 3.4 \% \text { ) meet the criteria for medium to high burnout. } \\
\text { The highest proportion of medical residents with burnout syndrome was } \\
\text { those in their second year of specialization in the area of pneumology }\end{array}$ \\
\hline
\end{tabular}




\begin{tabular}{|c|c|c|c|c|}
\hline $\begin{array}{l}\text { H1N1 } \\
\text { Mexico }\end{array}$ & $\begin{array}{l}\text { Medical residents } \\
\text { with different } \\
\text { fields of } \\
\text { specialization } \\
\text { related to } \\
\text { respiratory } \\
\text { medicine }\end{array}$ & & & $\begin{array}{l}(n=11 ; 52.4 \%) \text {. Medical residents under } 30 \text { years of age had a higher } \\
\text { probability of presenting burnout syndrome }\left(X^{2}=4.000 ; P=0.046\right) \text {. }\end{array}$ \\
\hline $\begin{array}{l}\text { Goulia 2010(10) } \\
\text { H1N1 } \\
\text { Greece }\end{array}$ & $\begin{array}{l}\text { Hospital } \\
\text { HCWs }\end{array}$ & $\mathrm{N}=469$ & $\begin{array}{l}\text { 20-item questionnaire, } \\
\text { Cassileth's Information } \\
\text { Styles Questionnaire } \\
\text { (part-I) and GHQ-28. }\end{array}$ & $\begin{array}{l}56.7 \% \text { reported being worried about } \mathrm{A} / \mathrm{H} 1 \mathrm{~N} 1 \text { influenza pandemic. The } \\
\text { level of anxiety was moderately high (median } 6 / 9) \text {. The most frequent } \\
\text { concern was infection of family and friends and the health consequences } \\
\text { of the disease }(54.9 \%) \text {. } \\
\text { The perceived risk of being infected was moderately high (median } 6 / 9) \text {. } \\
\text { Few HCWs }(6.6 \%) \text { had restricted their social contacts and fewer }(3.8 \%) \text { felt } \\
\text { isolated by their family members and friends because of their hospital } \\
\text { work, while a low percentage }(4.3 \%) \text { intended to take a leave to avoid } \\
\text { infection. Worry and degree of worry were significantly associated with } \\
\text { intended absenteeism }(\mathrm{P}<0.0005) \text {, restriction of social contacts }(\mathrm{P}<0.0005) \text {, } \\
\text { and psychological distress } \mathrm{P}=0.036) \text {. }\end{array}$ \\
\hline $\begin{array}{l}\text { Styra 2008(11) } \\
\text { SARS } \\
\text { Canada }\end{array}$ & $\begin{array}{l}\text { Clinical units at } \\
\text { tertiary care } \\
\text { healthcare } \\
\text { institution } \\
\text { HCWs }\end{array}$ & $\mathrm{N}=248$ & PTSD (IES) & $\begin{array}{l}\text { Factors that increased post-traumatic stress symptoms were: working in a } \\
\text { high-risk unit, }[B=0.76, S E 0.37, O R=2.2(1.0 \text { to } 4.4) ; P=0.04] \text {; attending only } \\
\text { one } S A R S \text { patient }[B=1.27, S E 0.50, O R=3.5(1.3 \text { to9.5); } P=0.01 ; \text { perception } \\
\text { of risk to self }[B=0.67, S E 0.19, O R=2.0(1.4 \text { to } 2.8) ; P<0.001] \text {; impact on } \\
\text { work life }[B=0.62, S E 0.19, O R=1.9(1.3 \text { to } 2.7) ; P=0.001] \text {; depressive affect } \\
\text { [ } B=0.79, S E 0.23, O R=2.2(1.4 \text { to } 03.5) ; P<0.001] \text {. }\end{array}$ \\
\hline
\end{tabular}




\begin{tabular}{|c|c|c|c|c|}
\hline $\begin{array}{l}\text { Loh 2006(12) } \\
\text { SARS } \\
\text { Malaysia }\end{array}$ & Medical School & $N=204$ & Anxiety (unclear) & $\begin{array}{l}\text { Phase } 1 \text { students expressed significantly a higher level of anxiety compared } \\
\text { to Phase II in relation to attendance and personal protection in hospitals, } \\
\text { and in meeting people coughing in public places. }\end{array}$ \\
\hline $\begin{array}{l}\text { Chan 2005(13) } \\
\text { SARS } \\
\text { China }\end{array}$ & $\begin{array}{l}\text { Hospital } \\
\text { Nurses }\end{array}$ & $\mathrm{N}=1470$ & $\begin{array}{l}\text { Stress (SARS Nurses' } \\
\text { Survey Questionnaire) }\end{array}$ & $\begin{array}{l}\text { Nurses in moderate-risk areas appeared to have more stress symptoms } \\
\text { than those working in high-risk areas. }\end{array}$ \\
\hline $\begin{array}{l}\text { Grace 2005(14) } \\
\text { SARS } \\
\text { Canada }\end{array}$ & $\begin{array}{l}\text { Hospital } \\
\text { Physicians }\end{array}$ & $N=193$ & $\begin{array}{l}\text { Psychological distress } \\
\text { (unclear) }\end{array}$ & $\begin{array}{l}\text { The rate of psychological distress was significantly higher among physicians } \\
\text { providing direct care to SARS patients }(45.7 \%, \mathrm{~N}=16) \text { than among } \\
\text { physicians not providing direct care }(17.7 \%, \mathrm{~N}=28)(\mathrm{P}<0.001) \text {. }\end{array}$ \\
\hline $\begin{array}{l}\text { Koh 2005(15) } \\
\text { SARS } \\
\text { Singapore }\end{array}$ & $\begin{array}{l}\text { Healthcare centers } \\
\text { HCWs }\end{array}$ & $\mathrm{N}=10511$ & $\begin{array}{l}\text { Intrusion and avoidance } \\
\text { (IES) }\end{array}$ & $\begin{array}{l}\text { More than half of the participants reported increased work stress }(56 \%) \\
\text { and workload ( } 53 \%) \text {. Many experienced social stigmatization }(49 \%) \text { and } \\
\text { ostracism by family members ( } 31 \%) \text {, but most ( } 77 \%) \text { felt appreciated by } \\
\text { society. }\end{array}$ \\
\hline
\end{tabular}




\begin{tabular}{|c|c|c|c|c|}
\hline $\begin{array}{l}\text { Lee } 2005(16) \\
\text { SARS } \\
\text { Taiwan }\end{array}$ & $\begin{array}{l}\text { Hospitals } \\
\text { Nurses }\end{array}$ & $\mathrm{N}=26$ & $\begin{array}{l}\text { Depression and anxiety } \\
\text { (SARS Team } \\
\text { Questionnaire) }\end{array}$ & $\begin{array}{l}\text { 12-31\% reported experiencing a mixture of various negative feelings, such } \\
\text { as anxiety, fear, depression and loss of control. }\end{array}$ \\
\hline $\begin{array}{l}\text { Tolomiczenko } \\
2005 \text { (17) } \\
\text { SARS } \\
\text { Canada }\end{array}$ & $\begin{array}{l}\text { Community } \\
\text { hospital } \\
\text { HCWs and } \\
\text { administrative } \\
\text { personnel }\end{array}$ & $N=300$ & Burnout (unclear) & $\begin{array}{l}\text { Statistically significant differences were found in burnout for gender } \\
\text { ( } 73.9 \% \text { women), nurses }(24.7 \%) \text { vs. others, physicians ( } 20.3 \%) \text { vs. others, } \\
\text { older ( } 40 \text { years or older, } 60.0 \% \text { ) vs. younger persons, emergency or ICU } \\
\text { workers ( } 8.0 \%) \text { vs. others, and those employed fewer years at the hospital } \\
\text { (less than } 5 \text { years: } 46.2 \%) \text { vs. five or more years. While all groups found } \\
\text { SARS stressful, nurses reported a greater impact on morale and job } \\
\text { satisfaction. }\end{array}$ \\
\hline $\begin{array}{l}\text { Bai 2004(18) } \\
\text { SARS } \\
\text { Taiwan }\end{array}$ & $\begin{array}{l}\text { Psychiatric } \\
\text { teaching hospital } \\
\text { Hospital staff } \\
\text { members (HCWs } \\
\text { and administrative } \\
\text { personnel) }\end{array}$ & $N=338$ & $\begin{array}{l}\text { Depression, anxiety and } \\
\text { stress (SARS-related } \\
\text { stress reactions } \\
\text { questionnaire) }\end{array}$ & $\begin{array}{l}17 \text { staff members (5\%) suffered acute stress disorder, } 44(11,2 \%) \\
\text { presented depressed mood and } 44(13 \%) \text { presented anxiety. }\end{array}$ \\
\hline $\begin{array}{l}\text { Chan 2004(19) } \\
\text { SARS } \\
\text { Singapore }\end{array}$ & $\begin{array}{l}\text { Regional general } \\
\text { hospital }\end{array}$ & $\mathrm{N}=661$ & $\begin{array}{l}\text { Depression (GHQ-28), } \\
\text { anxiety (GHQ-28) and } \\
\text { PTSD (IES) }\end{array}$ & $\begin{array}{l}177 \text { (27\%) participants had a GHQ } 28 \text { score } \geq 5 \text {, indicating the presence of } \\
\text { psychiatric symptoms. GHQ-28-depression means (SD) were } 0.6(1.1) \text { for } \\
\text { group A doctor (HCWs who were first-generation contacts or who had } \\
\text { direct contact with suspect or probable SARS patients), } 0.4(0.9) \text { for group } \\
\text { B doctor (HCWs who did not have direct contact with any suspect or } \\
\text { probable SARS patients), } 0.3(0.6) \text { for Group A nurse and } 0.4(1.0) \text { for group }\end{array}$ \\
\hline
\end{tabular}




\begin{tabular}{|c|c|c|c|c|}
\hline & $\begin{array}{l}\text { Physicians and } \\
\text { nurses }\end{array}$ & & & $\begin{array}{l}\text { B nurse. GHQ-28- anxiety means and SD were } 0.9 \text { (1.8) for group A doctor, } \\
0.8 \text { (1.4) for group B doctor, } 0.7(1.1) \text { for group } A \text { nurse and } 0.6(1.2) \text { for } \\
\text { group B nurse. Physicians }[\mathrm{P}=0.026, \mathrm{OR}=1.6 \text { and } 95 \% \mathrm{Cl}=1.1 \text { to } 2.5] \text { and } \\
\text { single } \mathrm{HCW} \text { s were at higher risk }(\mathrm{P}=0.048, \mathrm{OR}=1.4 \text { and } 95 \% \mathrm{Cl}=1.02 \\
\text { to2.0) compared to nurses and those who were married. Approximately, } \\
20 \% \text { of the participants had IES scores } \geq 30 \text {, indicating the presence of } \\
\text { PTSD. }\end{array}$ \\
\hline $\begin{array}{l}\text { Maunder } \\
2004(20) \\
\text { SARS } \\
\text { Canada }\end{array}$ & $\begin{array}{l}\text { Hospital } \\
\text { HCWs }\end{array}$ & $\mathrm{N}=1557$ & Psychological Stress (IES) & $\begin{array}{l}\text { Higher IES scores were observed in nurses and HCWs having contact with } \\
\text { patients with SARS. The relationship of these groups to the IES score was } \\
\text { mediated by three factors: health fear, social isolation, and job stress. }\end{array}$ \\
\hline $\begin{array}{l}\text { Nickell 2004(21) } \\
\text { SARS } \\
\text { Canada }\end{array}$ & $\begin{array}{l}\text { Tertiary hospital } \\
\text { HCWs }\end{array}$ & $N=2001$ & $\begin{array}{l}\text { Emotional distress (GHQ- } \\
\text { 12) }\end{array}$ & $\begin{array}{l}29 \% \text { of the respondents scored above the threshold point on the GHQ- } 12 \text {, } \\
\text { indicating probable emotional distress; the rate among nurses was } 45 \% \text {. }\end{array}$ \\
\hline $\begin{array}{l}\text { Poon 2004(22) } \\
\text { SARS } \\
\text { China }\end{array}$ & Hospital & $N=1926$ & $\begin{array}{l}\text { Anxiety (State-Trait } \\
\text { Anxiety Inventory), } \\
\text { burnout (unclear) }\end{array}$ & $\begin{array}{l}\text { Anxiety scores ranged from } 20 \text { to } 80 \text { and mean }(S D) \text { scores were higher } \\
\text { among staff who had had contact with patients with severe SARS than } \\
\text { among those who had not }(52.6 \text { [10.5] versus } 49.8 \text { [10.1], respectively; } \\
\text { ( } P<0.01) \text {. Mean anxiety levels were higher among workmen, healthcare } \\
\text { assistants, and nurses than among administrative staff controls or doctors } \\
(P<0.01) \text {. }\end{array}$ \\
\hline
\end{tabular}




\begin{tabular}{|c|c|c|c|c|}
\hline & $\begin{array}{l}\text { HCWs and } \\
\text { administrative } \\
\text { personnel }\end{array}$ & & & \\
\hline $\begin{array}{l}\text { Sim 2004(23) } \\
\text { SARS } \\
\text { Singapore }\end{array}$ & $\begin{array}{l}\text { Primary healthcare } \\
\text { center } \\
\text { Physicians and } \\
\text { nurses }\end{array}$ & $\mathrm{N}=277$ & $\begin{array}{l}\text { PTSD (IES-R), psychiatric } \\
\text { morbidity (GHQ-28) }\end{array}$ & 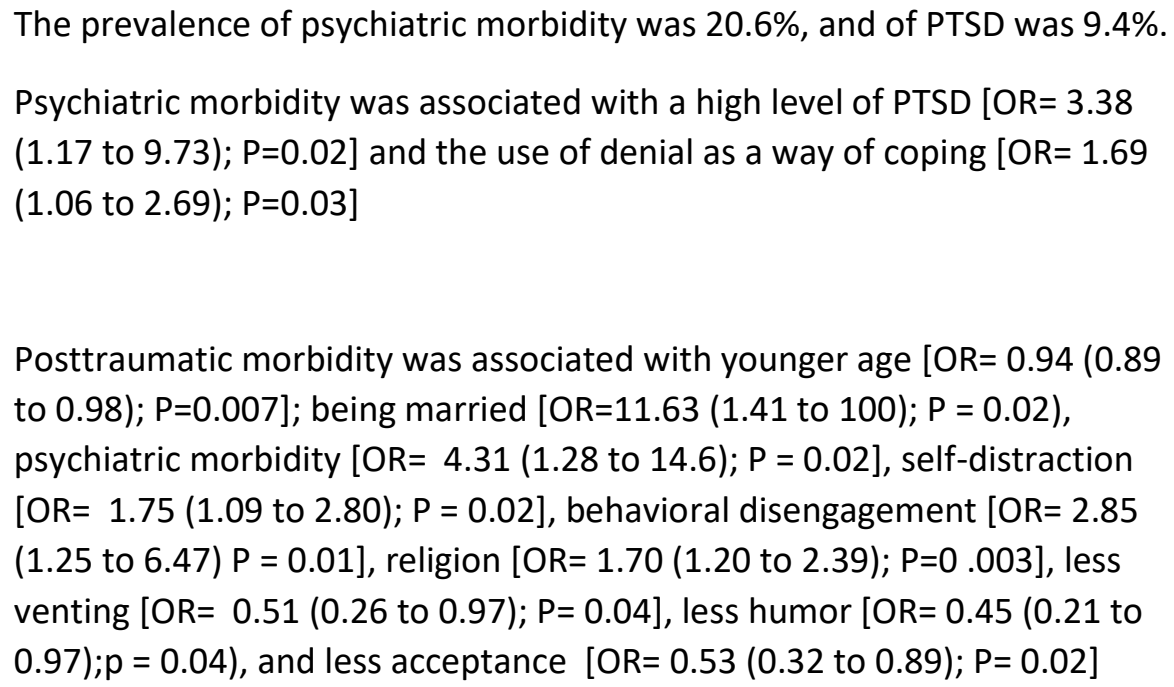 \\
\hline \multicolumn{5}{|c|}{ Cohort (prospective) studies } \\
\hline $\begin{array}{l}\text { Lee 2018(24) } \\
\text { MERS-CoV } \\
\text { South Korea }\end{array}$ & Hospital & $\mathrm{N}=359$ & PTSD (IES-R) & $\begin{array}{l}\text { The mean IES-R score was } 26.3 \pm 19.09 \text {. Of all respondents, } 230(64.1 \%) \\
\text { received a score of } 18 \text { or higher, indicating the presence of PTSD-like } \\
\text { symptoms, while } 183 \text { respondents }(51.5 \%) \text { exceeded the cut-off score of } \\
25 \text { for a diagnosis of PTSD. }\end{array}$ \\
\hline
\end{tabular}




\begin{tabular}{|c|c|c|c|c|}
\hline $\begin{array}{l}\text { Ji } 2017(25) \\
\text { Ebola } \\
\text { Sierra Leone / } \\
\text { China }\end{array}$ & $\begin{array}{l}\text { Hospital } \\
N=161 \\
\text { Sierra Leone (SL) } \\
\text { medical staff ( } n= \\
59), \text { SL logistic staff } \\
\text { ( } n=21 \text { ), SL medical } \\
\text { students ( } n=22 \text { ), } \\
\text { and Chinese } \\
\text { medical staff ( } n= \\
41 \text { ), the other } \\
\text { group consisted of } \\
\text { 18 EVD survivors. }\end{array}$ & $\mathrm{N}=161$ & $\begin{array}{l}\text { Psychological symptoms } \\
\text { (SCL-90-R) }\end{array}$ & $\begin{array}{l}\text { The mean of General Severity Index in EVD survivors, SL medical staff, SL } \\
\text { logistic staff, SL medical students, and Chinese medical staff were } 2.31 \pm \\
0.57,1.92 \pm 0.62,1.88 \pm 0.68,1.68 \pm 0.73 \text {, and } 1.25 \pm 0.23 \text {; Positive } \\
\text { Symptom Total (PST) were } 62.00 \pm 18.93,43.83 \pm 22.87,38.43 \pm 24.25 \text {, } \\
34.95 \pm 28.10 \text {, and } 16.76 \pm 10.79 \text {; Positive Symptom Distress Index (PSDI) } \\
\text { were } 3.43 \pm 0.47,5.07 \pm 2.64,6.85 \pm 5.47,7.79 \pm 7.00 \text {, and } 11.85 \pm 6.79 \text {, } \\
\text { respectively. } \\
\text { The order of total general severity index (GSI) scores from high to low was } \\
\text { EVD survivors, SL medical staff, SL logistic staff, SL medical students, and } \\
\text { Chinese medical staff. There were } 5 \text { dimensions (obsession-compulsion, } \\
\text { anxiety, hostility, phobic anxiety, and paranoid ideation) extremely high in } \\
\text { EVD survivors. GSI was inversely associated with university education. }\end{array}$ \\
\hline $\begin{array}{l}\text { Su } 2007(26) \\
\text { SARS } \\
\text { Taiwan }\end{array}$ & $\begin{array}{l}\text { Hospital } \\
\text { (structured SARS } \\
\text { caring unit) }\end{array}$ & $\mathrm{N}=102$ & $\begin{array}{l}\text { Depression (BDI), anxiety } \\
\text { (Spielberger trait anxiety } \\
\text { inventory), PTSD (Chinese } \\
\text { version of the Davidson } \\
\text { trauma scale), sleep } \\
\text { disturbance (PSQI) }\end{array}$ & $\begin{array}{l}\text { Depression ( } 38.5 \% \text { vs. } 3.1 \% \text { ) and insomnia ( } 37 \% \text { vs. } 9.7 \%) \text { were greater in } \\
\text { the SARS unit nurses than the non-SARS unit nurses. No difference was } \\
\text { found in the prevalence of PTSD symptoms ( } 33 \% \text { vs. } 18.7 \%) \text {, yet, three unit } \\
\text { subjects (SARS ICU, SARS regular and Neurology) had significantly higher } \\
\text { rate than those in CCU ( } 29.7 \% \text { vs. } 11.8 \% \text {, respectively) }(P<0.05) \text {. For the } \\
\text { SARS unit nurses, significant reduction in mood ratings, insomnia rate and } \\
\text { perceived negative feelings as well as increasing knowledge and } \\
\text { understanding of SARS at the end of the study (all P<0.001) indicated that } \\
\text { a gradual psychological adaptation had occurred. }\end{array}$ \\
\hline
\end{tabular}




\begin{tabular}{|c|c|c|c|c|}
\hline \multicolumn{5}{|c|}{ Case-control study } \\
\hline $\begin{array}{l}\text { Chen 2005(27) } \\
\text { Taiwan } \\
\text { SARS }\end{array}$ & $\begin{array}{l}\text { Wards or } \\
\text { emergency units } \\
\text { Nurses }\end{array}$ & $N=128$ & $\begin{array}{l}\text { Depression (SCR), anxiety } \\
\text { (SCR), PTSD (IES), } \\
\text { intrusion and avoidance } \\
\text { (IES), somatization, } \\
\text { interpersonal sensitivity, } \\
\text { hostility, psychoticism } \\
\text { (SCR) }\end{array}$ & $\begin{array}{l}11 \% \text { of the nurses had stress reaction syndrome. The symptoms of } \\
\text { psychological stress reactions included anxiety, depression, hostility, and } \\
\text { somatization. The highest rate of stress reaction syndrome was observed } \\
\text { in the group that originally worked in a high-risk unit, and the conscripted } \\
\text { group experienced the most severe distress on average. }\end{array}$ \\
\hline
\end{tabular}

BDI= Beck Depression Inventory; $\mathrm{Cl}=$ confidence Interval; COVID-19= Coronavirus disease; EVD= Ebola Virus Disease; GAD-7= Generalized Anxiety Disorder 7item; GHQ= General Health Questionnaire; GSES= General Self-Efficacy Scale; H1N1= H1N1 influenza virus; HCWs= healthcare workers ; ICU= intensive care unit; IES= Impact of Event Scale; MBIQ= Maslach Burnout Inventory questionnaire; MERS-CoV= Middle East respiratory syndrome coronavirus; $\mathrm{N}=$ sample size; OLBI= Oldenburg Burnout Inventory; OR= odds ratio; PHQ-9= Patient Health Questionnaire-9; PSQI= Pittsburgh Sleep Quality Index ; PTSD= PostTraumatic Stress Disorder; SARS= Severe acute respiratory syndrome; SAS= Self-Rating Anxiety Scale; SASR= Stanford Acute Stress Reaction; SCL-90-R= Symptom Checklist 90 Revised; SCR= Symptom Checklist-Revised; SD= standard deviation; SE= standard error; SSRS= Social Support Rate Scale. 
B. Summary of Findings table of studies examining the impact on mental health problems in healthcare workers after viral epidemics ( $N=27$ )

\begin{tabular}{|c|c|c|c|c|}
\hline $\begin{array}{l}\text { Author/ } \\
\text { year/health } \\
\text { emergency/ } \\
\text { country/ }\end{array}$ & $\begin{array}{l}\text { Setting } \\
\text { Type of } \\
\text { healthcare } \\
\text { professionals }\end{array}$ & Sample size (N) & $\begin{array}{l}\text { Mental health problem } \\
\text { (tool) }\end{array}$ & Main results \\
\hline \multicolumn{5}{|c|}{ Cross-sectional studies } \\
\hline $\begin{array}{l}\text { Park 2018(28) } \\
\text { MERS-Cov } \\
\text { South Korea }\end{array}$ & $\begin{array}{l}\text { Hospital } \\
\text { Nurses }\end{array}$ & $\mathrm{N}=187$ & $\begin{array}{l}\text { Mental Health (SF-36); } \\
\text { Stress (PSS-10); Hardiness } \\
\text { (DSR-15); Stigma (new } \\
\text { scale for study) }\end{array}$ & $\begin{array}{l}\text { Mental Health: a significant direct effect of stigma on mental health when } \\
\text { controlling for hardiness and stress }(\beta=-0.306, t=-7.2376, P<0.001) \\
\text { Hardiness exerted a significant direct effect on mental health when the } \\
\text { other variables were kept constant }(\beta=0.487, t=4.8692, P<0.001) \\
\text { The indirect effect of stigma on mental health was } 19.9 \% \text { of its direct effect } \\
\text { on mental health, while the indirect effect of hardiness was } 51.6 \% \text { of its } \\
\text { direct effect }\end{array}$ \\
\hline $\begin{array}{l}\text { Oh 2017(29) } \\
\text { MERS-Cov } \\
\text { South Korea }\end{array}$ & $\begin{array}{l}\text { Hospital } \\
\text { Nurses }\end{array}$ & $N=313$ & $\begin{array}{l}\text { Stress (12 questions } \\
\text { based on a trauma } \\
\text { appraisal questionnaire } \\
\text { and questionnaire } \\
\text { developed by the Korean } \\
\text { Neuro-Psychiatric } \\
\text { Association for medical }\end{array}$ & $\begin{array}{l}\text { The overall mean stress score of total study participants was } 32.91 \text {. } \\
\text { Nurses who provided either inpatient nursing care or screening services of } \\
\text { suspected or confirmed case (first hand): overall stress }=33.72\end{array}$ \\
\hline
\end{tabular}




\begin{tabular}{|c|c|c|c|c|}
\hline & & & $\begin{array}{l}\text { workers who experienced } \\
\text { the MERS outbreak) }\end{array}$ & $\begin{array}{l}\text { Nurses who participated in medical care of the general population with no } \\
\text { suspected MERS symptom (second hand): overall stress= } 32.25 \\
\text { (There was no statistically significant difference between the groups) } \\
\text { The regression estimate between stress and nursing intention was } B(S E)=- \\
0.08(0.02) \beta=-0.21 P<0.01 \text {. }\end{array}$ \\
\hline $\begin{array}{l}\text { Tang 2017(30) } \\
\text { H7N9 influenza } \\
\text { China }\end{array}$ & $\begin{array}{l}\text { Departments } \\
\text { admitting } \\
\text { H7N9 patients } \\
\text { HCWs }\end{array}$ & $\mathrm{N}=102$ & PTSD (PCL-C) & $\begin{array}{l}20.59 \% \text { showed PTSD symptoms. The sample had a mean PCL-C score of } \\
30 \pm 9.95 \text {. The differences in the scores of doctors and nurses with different } \\
\text { genders, ages, professional titles, contact frequencies, trainings, and } \\
\text { experiences were statistically significant }(\mathrm{P}<0.05, \mathrm{P}<0.01) \text {. Moreover, t- } \\
\text { tests and one-way analysis of variance showed that nurses received higher } \\
\text { scores than doctors, female participants received higher scores than male } \\
\text { participants, and the participants with low professional title and high } \\
\text { contact frequency, aged between } 20 \text { years and } 30 \text { years, with less than five } \\
\text { years of work experience, having not received related training and with no } \\
\text { related experience obtained higher } P C L-C \text { scores than the others }(P<0.05 \text {, } \\
P<0.01) \text {. }\end{array}$ \\
\hline $\begin{array}{l}\text { Lehmann } \\
\text { 2016(31) } \\
\text { Ebola } \\
\text { Germany }\end{array}$ & $\begin{array}{l}\text { Hospital and } \\
\text { research } \\
\text { institute } \\
\text { HCWs, and } \\
\text { general staff }\end{array}$ & $\mathrm{N}=86$ & $\begin{array}{l}\text { Depression (PHQ-9), } \\
\text { anxiety (GAD-7), general } \\
\text { mental health (SF12) }\end{array}$ & $\begin{array}{l}\text { Ebola patient treatment group experienced significantly higher levels of } \\
\text { social isolation than both other groups. The best predictors of poor } \\
\text { physical and mental HrQoL were perceived lack of knowledge about the } \\
\text { Ebola virus disease (physical: } \beta=-1.2, P=0.05 ; \text { mental: } \beta=-1.3, P=0.03 \text { ) and } \\
\text { fatigue (physical: } \beta=-0.3, P=0.02 ; \text { mental: } \beta=-0.53, P<0.001 \text { ). }\end{array}$ \\
\hline
\end{tabular}




\begin{tabular}{|c|c|c|c|c|}
\hline $\begin{array}{l}\text { SARS } \\
\text { China }\end{array}$ & Hospital & $\mathrm{N}=549$ & $\begin{array}{l}\text { Depression (CES-D - } \\
\text { Chinese version), PTSD } \\
\text { (IES-R - Adapted and } \\
\text { validated in Chinese) }\end{array}$ & $\begin{array}{l}\text { The results of multinomial regression analyses showed that, with other } \\
\text { relevant factors controlled for, being single, having been quarantined } \\
\text { during the outbreak, having been exposed to other traumatic events } \\
\text { before SARS, and perceived SARS-related risk level during the outbreak } \\
\text { were found to increase the odds of having a high level of depressive } \\
\text { symptoms } 3 \text { years later. Altruistic acceptance of risk during the outbreak } \\
\text { was found to decrease the odds of high post-outbreak depressive } \\
\text { symptom levels }\end{array}$ \\
\hline $\begin{array}{l}\text { Matsuishi } \\
\text { 2012(33) } \\
\text { H1N1 } \\
\text { Japan }\end{array}$ & $\begin{array}{l}\text { Hospital } \\
\text { HCWs }\end{array}$ & $N=1625$ & $\begin{array}{l}\text { Anxiety (19 stress-related } \\
\text { questions), PTSD (IES) }\end{array}$ & $\begin{array}{l}\text { Workers at a hospital with intense liaison psychiatric services felt less } \\
\text { psychological impact. Workers at a hospital that provided staff with } \\
\text { information about the pandemic less frequently, felt unprotected. Workers } \\
\text { in work environments that had a high risk of infection felt more anxious } \\
\text { and more exhausted. The total IES score was higher in workers in high-risk } \\
\text { work environments. }\end{array}$ \\
\hline Lancee 2008(34) & $\begin{array}{l}\text { Academic and } \\
\text { community } \\
\text { hospitals }\end{array}$ & $N=139$ & $\begin{array}{l}\text { Depression, anxiety } \\
\text { (Kessler Psychological } \\
\text { Distress Scale), PTSD } \\
\text { (IES), burnout (MBly) }\end{array}$ & $\begin{array}{l}\text { The lifetime prevalence of any depressive, anxiety, or substance use } \\
\text { diagnosis was } 30 \% \text {. Only one HCW who identified the SARS experience as a } \\
\text { traumatic event was diagnosed as having PTSD. New episodes of } \\
\text { psychiatric disorders occurred among seven healthcare workers ( } 5 \%) \text {. New } \\
\text { episodes of psychiatric disorders were directly associated with a history of } \\
\text { having a psychiatric disorder before the SARS outbreak }(P=0.02) \text { and } \\
\text { inversely associated with years of healthcare experience }(P=0.03) \text { and the } \\
\text { perceived adequacy of training and support }(P=0.03) \text {. }\end{array}$ \\
\hline
\end{tabular}




\begin{tabular}{|c|c|c|c|c|}
\hline Wu 2008(35) & Hospital & $N=549$ & PTSD (IES-R) & $\begin{array}{l}\text { Current alcohol abuse/dependence symptom counts } 3 \text { years after the } \\
\text { outbreak were positively associated with having been quarantined, or } \\
\text { worked in high-risk locations such as SARS wards, during the outbreak. } \\
\text { However, having had family members or friends contract, SARS was not } \\
\text { related to alcohol abuse/dependence symptom count. Symptoms of PTS } \\
\text { and of depression, and having used drinking as a coping method, were also } \\
\text { significantly associated with increased alcohol abuse/dependence } \\
\text { symptoms. The relationship between outbreak exposure and alcohol } \\
\text { abuse/dependence symptom count remained significant even when } \\
\text { sociodemographic and other factors were controlled for. When the } \\
\text { intrusion, avoidance and hyperarousal PTS symptom clusters were entered } \\
\text { into the model, hyperarousal was found to be significantly associated with } \\
\text { alcohol abuse/dependence symptoms }\end{array}$ \\
\hline Chen 2007 (36) & $\begin{array}{l}\text { Tertiary care } \\
\text { referral center } \\
\\
66(73.3 \%) \\
\text { critical care } \\
\text { nurses, } 11 \\
(12.2 \%) \\
\text { physicians, } 7 \\
(7.8 \%) \\
\text { technicians, } \\
\text { and } 6(6.7 \%) \\
\text { respiratory }\end{array}$ & $\mathrm{N}=172$ & $\begin{array}{l}\text { Role emotional, and } \\
\text { mental health: MOS SF-36 }\end{array}$ & $\begin{array}{l}\text { All serum specimens tested negative for SARS antibody. Survey scores for } \\
\text { SARS HCWs immediately after care were significantly lower than those for } \\
\text { the control group ( } P<0.05 \text { by the } t \text { test) in } 6 \text { categories. Vitality, social } \\
\text { functioning, and mental health immediately after care and vitality and } \\
\text { mental health after self-quarantine and off-duty shifts were among the } \\
\text { worst subscales. The social functioning, role emotional, and role physical } \\
\text { subscales significantly improved after self-quarantine and off-duty shifts ( } P \\
<0.05 \text {, by paired t test). The length of contact time (mean number of } \\
\text { contact-hours per day) with patients with SARS was associated with some } \\
\text { subscales (role emotional, role physical, and mental health) to a mild } \\
\text { extent. The total number of contact-hours with symptomatic patients with } \\
\text { SARS was a borderline predictor (adjusted } \mathrm{R}^{2}=0.069 ; \mathrm{P}=0.038 \text { ) of mental } \\
\text { health score. }\end{array}$ \\
\hline
\end{tabular}




\begin{tabular}{|c|c|c|c|c|}
\hline & $\begin{array}{l}\text { care } \\
\text { specialists. }\end{array}$ & & & \\
\hline $\begin{array}{l}\text { Lin } 2007(37) \\
\text { SARS } \\
\text { Taiwan }\end{array}$ & $\begin{array}{l}\text { Hospital } \\
\text { Physicians and } \\
\text { nurses }\end{array}$ & $\mathrm{N}=92$ & PTSD (DTS-C) & $\begin{array}{l}86 \text { of } 92(93.5 \%) \text { medical staff considered the SARS outbreak to be a } \\
\text { traumatic experience. The DTS-C scores of staff in the emergency } \\
\text { department and in the psychiatric ward were significantly different ( } P= \\
0.04) \text {. Emergency department staff had more severe PTSD symptoms than } \\
\text { staff in the psychiatric ward }\end{array}$ \\
\hline $\begin{array}{l}\text { Marjanovic } \\
2007(38) \\
\text { SARS } \\
\text { Canada }\end{array}$ & $\begin{array}{l}\text { Healthcare } \\
\text { facilities } \\
\text { Nurses }\end{array}$ & $N=333$ & $\begin{array}{l}\text { Emotional exhaustion } \\
\text { (MBI-GS); state anger } \\
\text { (adapted version of } \\
\text { STAXI-2); Avoidance } \\
\text { behavior ( } 6 \text { items) }\end{array}$ & $\begin{array}{l}\text { Emotional exhaustion: Less contact with SARS patients }(\beta=-0.15 ; P=0.003) \text {, } \\
\text { higher levels of vigor }(\beta=0.34 ; P<0.001) \text {, greater trust in } \\
\text { equipment/infection control initiatives }(\beta=-0.15 ; P=0.005) \text {, predicted } \\
\text { significantly lower levels of emotional exhaustion. } \\
\text { Avoidance behavior: Less time spent in quarantine }(\beta=0.23 ; P<0.001) \text {, } \\
\text { higher levels of vigor ( } \beta=0.27 ; P<001) \text { and higher organizational support } \\
(\beta=0.26 ; P<001) \text { predicted significantly less avoidance behavior. } \\
\text { State anger: Less time in quarantine }(\beta=0.14 ; P=0.008) \text {, higher levels of } \\
\text { organizational support ( } \beta=0.24 ; P=<0.001) \text { vigor }(\beta=-0.20 ; P=<0.001) \text { and } \\
\text { trust in equipment/infection control initiatives }(\beta=-0.14 ; P=0.011) \\
\text { predicted lower levels of state anger }\end{array}$ \\
\hline
\end{tabular}




\begin{tabular}{|c|c|c|c|c|}
\hline $\begin{array}{l}\text { Wong 2007(39) } \\
\text { SARS } \\
\text { China and } \\
\text { Canada }\end{array}$ & $\begin{array}{l}\text { Community } \\
\text { based primary } \\
\text { care clinics } \\
\text { Family } \\
\text { medicine } \\
\text { tutors }\end{array}$ & $\mathrm{N}=188$ & $\begin{array}{l}\text { Anxiety (a visual analogue } \\
\text { scale ranging from } \\
\text { extremely frightened } \\
\text { (high score) to not } \\
\text { frightened at all (zero } \\
\text { score). }\end{array}$ & $\begin{array}{l}51 \% \text { in Canada and } 50.7 \% \text { in Hong Kong, were classified in the high-anxiety } \\
\text { group. }\end{array}$ \\
\hline $\begin{array}{l}\text { Fiksenbaum } \\
\text { 2006(40) } \\
\text { SARS } \\
\text { Canada }\end{array}$ & $\begin{array}{l}\text { Multiple } \\
\text { settings } \\
\text { (community } \\
\text { health, } \\
\text { surgical and } \\
\text { pediatrics) } \\
\text { Nurses }\end{array}$ & $\mathrm{N}=333$ & $\begin{array}{l}\text { Emotional exhaustion } \\
\text { (MBI-GS); State anger } \\
\text { (STAXI) }\end{array}$ & $\begin{array}{l}\text { Working conditions contributed significantly to an increase in perceived } \\
\text { SARS threat, which led to increased emotional exhaustion }(\beta=0.44) \text { and } \\
\text { state anger }(\beta=0.41) \text {. Lower perceived organizational support was related } \\
\text { to increased feelings of emotional exhaustion }(\beta=0.11) \text { and state anger } \\
(\beta=0.26) \text {. }\end{array}$ \\
\hline
\end{tabular}




\begin{tabular}{|c|c|c|c|c|}
\hline $\begin{array}{l}\text { Lu 2006(41) } \\
\text { SARS } \\
\text { Taiwan }\end{array}$ & $\begin{array}{l}\text { Hospital } \\
\text { HCWs: } \\
\text { physicians, } \\
\text { nurses and } \\
\text { others }\end{array}$ & $\mathrm{N}=127$ & $\begin{array}{l}\text { Extraversion, neuroticism } \\
\text { (EPQ). Psychiatric } \\
\text { Morbidity (CHQ). } \\
\text { Paternal/maternal care } \\
\text { and protection (PBI) }\end{array}$ & $\begin{array}{l}\text { Twenty-two (17.3\%) developed significant mental symptoms, and } 105 \\
(82.7 \%) \text { showed no obvious symptoms. The structural equation model } \\
\text { showed that maternal care }(\beta=-0.18, P=0.011) \text { and neuroticism }(\beta=0.54 \text {, } \\
P<10^{-6} \text { ) directly influenced the ability of HCWs to deal with the impact of } \\
\text { SARS. Maternal overprotection }(\beta=-0.30, P<0.05) \text { had an indirect influence } \\
\text { on the ability to cope with the impact of SARS. }\end{array}$ \\
\hline $\begin{array}{l}\text { Maunder } \\
2006(42) \\
\text { SARS } \\
\text { Canada }\end{array}$ & $\begin{array}{l}\text { Hospital } \\
\text { HCWs }\end{array}$ & $N=769$ & PTSD (IES) & $\begin{array}{l}\text { From } 13 \text { to } 26 \text { months after the SARS outbreak, } 769 \mathrm{HCWs} \text { at } 9 \text { Toronto } \\
\text { hospitals that treated SARS patients and } 4 \text { Hamilton hospitals that did not } \\
\text { treat SARS patients completed a survey of several adverse outcomes. } \\
\text { Toronto HCWs reported significantly higher levels of burnout }(\mathrm{P}=0.019) \text {, } \\
\text { psychological distress ( } \mathrm{P}<0.001 \text { ), and posttraumatic stress ( } \mathrm{P}<0.001) \text {. } \\
\text { Toronto workers were more likely to have reduced patient contact and } \\
\text { work hours and to report behavioral consequences of stress. Variance in } \\
\text { adverse outcomes was explained by a protective effect of the perceived } \\
\text { adequacy of training and support and by a provocative effect of } \\
\text { maladaptive coping style and other individual factors. }\end{array}$ \\
\hline Ho 2005 (43) & Hospitals & $N=97$ & PTSD (CIES-R) & $\begin{array}{l}\text { Participants with lower self-efficacy tended to have higher fear related to } \\
\text { SARS }(P<0.05) \text {. The mean scores of the three } C \text { IES-R subscales ranged from } \\
1.24 \text { to } 1.57 \text {, with Intrusion scoring highest. Fear related to SARS was also } \\
\text { correlated positively with posttraumatic stress symptoms among } \\
\text { respondents }(P<0.01) \text {. }\end{array}$ \\
\hline
\end{tabular}




\begin{tabular}{|c|c|c|c|c|}
\hline $\begin{array}{l}\text { Phua 2005(44) } \\
\text { SARS } \\
\text { Singapore }\end{array}$ & $\begin{array}{l}\text { Hospital } \\
\text { Physicians and } \\
\text { nurses }\end{array}$ & $\mathrm{N}=99$ & $\begin{array}{l}\text { Psychiatric morbidity (IES } \\
\text { and GHQ) }\end{array}$ & $\begin{array}{l}\text { Psychiatric morbidity was } 17.7 \% \text { on the IES and } 18.8 \% \text { on the GHQ } 28 \text {, with } \\
\text { the trend for physicians to report lower psychiatric morbidity. }\end{array}$ \\
\hline $\begin{array}{l}\text { Tham 2005(45) } \\
\text { SARS } \\
\text { Singapore }\end{array}$ & $\begin{array}{l}\text { Hospital } \\
\text { Physicians and } \\
\text { nurses }\end{array}$ & $N=96$ & $\begin{array}{l}\text { Depression, anxiety (GHQ } \\
28 \text { ), PTSD (IES), somatic } \\
\text { symptoms, insomnia, } \\
\text { social dysfunction (GHQ } \\
28 \text { ) }\end{array}$ & $\begin{array}{l}\text { Thirty-eight out of } 41 \text { ( } 92.7 \%) \text { doctors and } 58 \text { out of } 83(69.9 \%) \text { nurses } \\
\text { responded. Fewer doctors reported post-event and psychiatric morbidity } \\
\text { compared to nurses, with } 5(13.2 \%) \text { doctors and } 12(20.7 \%) \text { nurses scoring } \\
\geq 26 \text { on IES, } 6(15.8 \%) \text { doctors and } 12(20.7 \%) \text { nurses scoring } \geq 5 \text { on GHQ } 28 \text {. } \\
\text { The doctors reported a median of } 9.5 \text { (range } 0-47 \text { ) on IES and } 0 \text { (range } 0- \\
\text { 11) on GHQ } 28 \text {. The nurses reported a median of } 15 \text { (range } 0-61 \text { ) on IES } \\
\text { and } 1 \text { (range } 0-25 \text { ) on GHQ } 28 \text {. }\end{array}$ \\
\hline $\begin{array}{l}\text { Wong 2005(46) } \\
\text { SARS } \\
\text { China }\end{array}$ & $\begin{array}{l}\text { Emergency } \\
\text { Department of } \\
\text { public hospital } \\
\text { HCWs }\end{array}$ & $\mathrm{N}=466$ & $\begin{array}{l}\text { Mental distress (unclear), } \\
\text { coping strategies } \\
\text { (Chinese version of the } \\
\text { Brief Cope) }\end{array}$ & The mean overall distress level was 6.19 out of a 10-point scale. \\
\hline $\begin{array}{l}\text { Chua } 2004 \text { (47) } \\
\text { SARS } \\
\text { China }\end{array}$ & $\begin{array}{l}\text { Hospitals } \\
\text { HCWs, mostly } \\
\text { nurses (60\%) }\end{array}$ & $\mathrm{N}=613$ & StressPSS-10 & $\begin{array}{l}\text { Stress levels were raised in both groups ( } P S S=18) \text { but were not relatively } \\
\text { increased in the HCWs. HCWs reported significantly more positive }(94 \% \text {, } \\
\mathrm{N}=256 \text { ) and more negative psychological effects ( } 89 \%, \mathrm{~N}=241 \text { ) from SARS } \\
\text { than did control subjects. HCWs declared confidence in infection-control } \\
\text { measures. }\end{array}$ \\
\hline
\end{tabular}




\begin{tabular}{|c|c|c|c|c|}
\hline Tam 2004(48) & $\begin{array}{l}\text { Hospital } \\
\text { (medical units } \\
\text { and intensive } \\
\text { care units) } \\
\text { HCWs }\end{array}$ & $\mathrm{N}=652$ & $\begin{array}{l}\text { Subjective job related } \\
\text { stress levels ( } 2 \text { Likert-type } \\
\text { questions); Psychological } \\
\text { morbidity (GHQ-12) }\end{array}$ & $\begin{array}{l}68 \% \text { reported a high level of stress. About } 57 \% \text { were found to have } \\
\text { experienced psychological distress. The HCWs' psychological morbidity was } \\
\text { best understood by the perceptions of personal vulnerability, stress and } \\
\text { support in the workplace. }\end{array}$ \\
\hline $\begin{array}{l}\text { Verma 2004(49) } \\
\text { SARS } \\
\text { Singapore }\end{array}$ & $\begin{array}{l}\text { Unspecified } \\
\text { Physicians and } \\
\text { Traditional } \\
\text { Chinese } \\
\text { Medicine } \\
\text { (TCM) } \\
\text { Practitioners }\end{array}$ & $\mathrm{N}=1050$ & $\begin{array}{l}\text { Depression, anxiety (GHQ } \\
\text { 28), PTSD (IES), } \\
\text { perception of stigma } \\
\text { (Questionnaire adopted } \\
\text { from the HSS). }\end{array}$ & $\begin{array}{l}\text { A total of } 721 \text { ( } 29 \%) \text { GPs and } 329(22 \%) \text { TCM practitioners responded to } \\
\text { the survey. Significantly more GPs had worked in SARS affected facilities } \\
\text { and had been directly involved in the care of patients with SARS than the } \\
\text { TCM practitioners ( } P<0.001) \text {. Those GPs who were directly involved in the } \\
\text { care of patients with SARS were significantly more likely to be GHQ cases } \\
\text { as compared to those not involved in the care of patients with SARS } \\
(P=0.02 ; O R=2.9 ; 95 \% \mathrm{Cl}, 1.3 \text { to } 6.3) \text {. The mean score of the GHQ somatic, } \\
\text { anxiety and social dysfunction subscales were significantly higher in GPs as } \\
\text { compared to TCM Practitioners ( } P<0.001) \text {. The GHQ total score as well as } \\
\text { the subscales was significantly correlated with the IES-R and stigma } \\
\text { subscales }(P<0.05) \text {. }\end{array}$ \\
\hline $\begin{array}{l}\text { Wong 2004(50) } \\
\text { SARS } \\
\text { China }\end{array}$ & $\begin{array}{l}\text { Community } \\
\text { based primary } \\
\text { care clinics } \\
\text { Medicine } \\
\text { Tutors }\end{array}$ & $N=137$ & Anxiety (unclear) & $\begin{array}{l}\text { All agreed SARS had changed their clinical practices. Significant anxiety was } \\
\text { found in family doctors. Three quarters of respondents recalled requesting } \\
\text { more investigations while a quarter believed they had over-prescribed } \\
\text { antibiotics. GPs who were exposed to SARS or who had worked in high } \\
\text { infection districts were less likely to quarantine themselves ( } 10.8 \% \text { versus } \\
33.3 \% ; \mathrm{P}<0.01 ; 6.5 \% \text { versus } 27.5 \% ; \mathrm{P}<0.01 \text { respectively). Exposure to SARS, } \\
\text { the infection rates in their working district, and anxiety levels had } \\
\text { significant impact on the level of protection or prescribing behaviour. }\end{array}$ \\
\hline
\end{tabular}




\begin{tabular}{|c|c|c|c|c|}
\hline \multicolumn{5}{|c|}{ Systematic review } \\
\hline $\begin{array}{l}\text { Brooks } 2018 \\
(51) \\
\text { SARS } \\
\text { Worldwide }\end{array}$ & $\begin{array}{l}\text { Multiple } \\
\text { settings } \\
\text { HCWs }\end{array}$ & NR (22 studies) & $\begin{array}{l}\text { Depression, anxiety, } \\
\text { PTSD, job-related stress }\end{array}$ & $\begin{array}{l}\text { The psychological impact of SARS on HCWs appeared to be associated with } \\
\text { occupational role; training/preparedness; high-risk work environments; } \\
\text { quarantine; role-related stressors; perceived risk; social support; social } \\
\text { rejection/isolation; and impact of SARS on personal or professional life. }\end{array}$ \\
\hline \multicolumn{5}{|c|}{ Cohort (prospective) studies } \\
\hline $\begin{array}{l}\text { Lung 2009(52) } \\
\text { SARS } \\
\text { Taiwan }\end{array}$ & $\begin{array}{l}\text { Hospital } \\
\text { HCWs: } \\
\text { doctors, } \\
\text { nurses and } \\
\text { others } \\
\text { (medical } \\
\text { technicians, } \\
\text { respiratory } \\
\text { therapists, or } \\
\text { emergency } \\
\text { attendant) }\end{array}$ & $\mathrm{N}=127$ & $\begin{array}{l}\text { Extraversion, neuroticism } \\
\text { (EPQ). Psychiatric } \\
\text { Morbidity (CHQ). } \\
\text { Paternal/maternal care } \\
\text { and protection (PBI) }\end{array}$ & $\begin{array}{l}\text { The first stage symptom results had a positive direct effect on the second } \\
\text { stage results (somatic symptoms: } \beta=0.31, P<0.05 \text {; negative affect: } \beta=0.23 \text {, } \\
P=0.006 \text { ). The participants presented more somatic symptoms than } \\
\text { negative affect at both stages (accounting for } 35 \% \text { and } 19 \% \text { of the } \\
\text { variance, respectively). Daily-life stressful events had impact on both } \\
\text { dimensions of mental health, which included somatic symptoms ( } \beta=0.18 \text {, } \\
P=0.034 \text { ) and negative affect ( } \beta=0.30, P<0.05 \text { ). Nurses had fewer somatic } \\
\text { realm that other healthcare workers ( } \beta=-0.15, P<0.05 \text { ). Participants who } \\
\text { had negative effect at the initial assessment had fewer somatic symptoms } \\
(\beta=-0.21, P<0.05 \text { ) the following year. Negative affect had impact on } \\
\text { somatic symptoms at both assessment stages (initial stage: } \beta=0.25, P<0.05 \text {; } \\
\text { follow-up stage: } \beta=0.24, P<0.05 \text { ) }\end{array}$ \\
\hline
\end{tabular}




\begin{tabular}{|c|c|c|c|c|}
\hline $\begin{array}{l}\text { Wu 2009(53) } \\
\text { SARS } \\
\text { China }\end{array}$ & $\begin{array}{l}\text { Hospitals } \\
\text { HCWs }\end{array}$ & $\mathrm{N}=549$ & PTSD (IES-R) & $\begin{array}{l}\text { About } 10 \% \text { of the respondents had experienced high levels of } \\
\text { posttraumatic stress (PTS) symptoms since the SARS outbreak. } \\
\text { Respondents who had been quarantined, or worked in high-risk locations } \\
\text { such as SARS wards, or had friends or close relatives who contracted SARS, } \\
\text { were } 2 \text { to } 3 \text { times more likely to have high PTS symptom levels, than those } \\
\text { without these exposures. Respondents' perceptions of SARS-related risks } \\
\text { were significantly positively associated with PTS symptom levels and } \\
\text { partially mediated the effects of exposure. Altruistic acceptance of work- } \\
\text { related risks was negatively related to PTS levels. }\end{array}$ \\
\hline $\begin{array}{l}\text { McAlonan } \\
2007(54) \\
\text { SARS } \\
\text { China }\end{array}$ & $\begin{array}{l}\text { Hospitals } \\
\text { HCWs }\end{array}$ & $\mathrm{N}=176$ & $\begin{array}{l}\text { Depression, anxiety } \\
\text { (DASS-21), PTSD (IES), } \\
\text { stress (PSS-10) }\end{array}$ & $\begin{array}{l}\text { In } 2003 \text {, high-risk health care workers had elevated stress levels (PSS-10 } \\
\text { score = 17.0) that were not significantly different from levels in low-risk } \\
\text { HCW control subjects (PSS-10 score=15.9). More high-risk HCWs reported } \\
\text { fatigue, poor sleep, worry about health, and fear of social contact, despite } \\
\text { their confidence in infection-control measures. By 2004, however, stress } \\
\text { levels in the high-risk group were not only higher (PSS-10 score=18.6) but } \\
\text { also significantly higher than scores among low-risk HCW control subjects } \\
\text { (PSS-10 score=14.8, P<0.05). In } 2004 \text {, the perceived stress levels in the } \\
\text { high-risk group were associated with higher depression, anxiety, and } \\
\text { posttraumatic stress scores }(P<0.001) \text {. }\end{array}$ \\
\hline
\end{tabular}

CES-D= Center for Epidemiologic Studies Depression Scale; CHQ= Chinese Health Questionnaire; $\mathrm{Cl}=$ confidence interval; CIES-R= Chinese Impact of Event Scale-Revised; DASS-21: Depression= Anxiety and Stress Scale - 21 Items; DRS-15= Dispositional Resilience Scale-15; DTS-C= Davidson Trauma Scale Chinese Version; EPQ= Eysenck Personality Questionnaire; GAD-7= Generalized Anxiety Disorder 7-item; GHQ= General Health Questionnaire; GP= general 
practitioner; H1N1: H1N1 influenza virus; HCWs= health care workers; HrQoL= Health-related quality of life; HSS= HIV Stigma Scale; IES= Impact of Events Scales; IES-R= Impact of Event Scale-Revised; MBI-GS= Maslach Burnout Inventory -General Survey; MERS-CoV: Middle East respiratory syndrome coronavirus; MOS SF-36= Medical Outcome Study Short-Form 36 Survey; OR= odds ratio; PBI= Parental Bonding Instrument; PCL-C= PTSD Checklist-Civilian Version; PHQ-9= Patient Health Questionnaire-9; PSS-10= 10-item Perceived Stress Scale; PTSD= Post-Traumatic Stress Disorder; SARS= severe acute respiratory syndrome; SE= standard error; SF12= 12-item Short Form Health Survey; SF-36= Short Form-36 questionnaire; STAXI-2= State-Trait Anger Expression Inventory. 


\section{Summary of Findings table of studies examining the impact on mental health problems in healthcare workers during and after viral epidemics}

$(\mathrm{N}=2)$

\begin{tabular}{|c|c|c|c|c|}
\hline $\begin{array}{l}\text { Author/ } \\
\text { year/health } \\
\text { emergency/ } \\
\text { country/ }\end{array}$ & $\begin{array}{l}\text { Setting } \\
\text { Type of } \\
\text { healthcare } \\
\text { professionals }\end{array}$ & Sample size (N) & $\begin{array}{l}\text { Mental health problem } \\
\text { (tool) }\end{array}$ & Main results \\
\hline $\begin{array}{l}\text { SARS } \\
\text { China }\end{array}$ & $\begin{array}{l}\text { Hospitals } \\
\text { HCWs }\end{array}$ & $\begin{array}{l}\text { Cohort } \\
\text { (prospective) } \\
\mathrm{N}=33\end{array}$ & $\begin{array}{l}\text { Depression, anxiety (DASS- } \\
\text { 21), Subjective stress (PSS- } \\
\text { 10), PTSD (IER-R), } \\
\text { psychiatric morbidity } \\
\text { (GHQ-12) }\end{array}$ & $\begin{array}{l}\text { SARS survivors had higher stress levels during the outbreak, compared } \\
\text { with control subjects (PSS-10 scores }=19.8 \text { and } 17.9 \text {, respectively; } \\
P<0.01 \text { ). SARS survivors had stress levels similar to those of non-HCWs, } \\
\text { but HCWs showed significantly higher stress levels in } 2004 \text { (PSS-10 } \\
\text { score }=22.8 \text {, compared with PSS-10 score }=18.4 ; P<0.05 \text { ) and had higher } \\
\text { depression }(P<0.01) \text {, anxiety }(P<0.001) \text {, posttraumatic symptoms } \\
\text { (Intrusion } P<0.001, \text { Avoidance } P<0.05 \text { and Hyperarousal } P<0.05) \text {, and } \\
\text { GHQ-12 scores }(P<0.001) \text {. }\end{array}$ \\
\hline SARS & $\begin{array}{l}\text { Tertiary hospital } \\
\text { HCWs }\end{array}$ & $\begin{array}{l}\text { Cross-sectional } \\
N=1,257\end{array}$ & $\begin{array}{l}\text { Depression (CHQ), anxiety } \\
\text { (CHQ), intrusion and } \\
\text { avoidance (IES), and } \\
\text { somatization (CHQ) }\end{array}$ & $\begin{array}{l}\text { In the initial phase of the outbreak, when the infection was spreading } \\
\text { rapidly, feelings of extreme vulnerability, uncertainty and threat to life } \\
\text { were perceived, dominated by somatic and cognitive symptoms of } \\
\text { anxiety. During the 'repair' phase, when the infection was being } \\
\text { brought under control, depression and avoidance were evident. } \\
\text { Prevalence of psychiatric morbidity (CHQ) about 75\%. }\end{array}$ \\
\hline
\end{tabular}

$\mathrm{CHQ}=$ Chinese Health Questionnaire; DASS-21= Depression= Anxiety and Stress Scale -21 Items; GHQ-12=12-item General Health Questionnaire; HCWs= healthcare workers; IES= Impact of Events Scales; PSS-10= Perceived Stress Scale; PTSD= Post-Traumatic Stress Disorder; SARS= severe acute respiratory syndrome. 
medRxiv preprint doi: https://doi.org/10.1101/2020.04.02.20048892; this version posted April 6, 2020. The copyright holder for this preprint (which was not certified by peer review) is the author/funder, who has granted medRxiv a license to display the preprint in perpetuity. It is made available under a CC-BY-ND 4.0 International license .

\section{REFERENCES}

1. Lai J, Ma S, Wang Y, Cai Z, Hu J, Wei N, et al. Factors Associated With Mental Health Outcomes Among Health Care Workers Exposed to Coronavirus Disease 2019. JAMA Network Open. 2020;3(3):e203976-e.

2. Li Z, Ge J, Yang M, Feng J, Qiao M, Jiang R, et al. Vicarious traumatization in the general public, members, and non-members of medical teams aiding in COVID-19 control. Brain, behavior, and immunity. 2020.

3. Xiao H, Zhang Y, Kong D, Li S, Yang N. The Effects of Social Support on Sleep Quality of Medical Staff Treating Patients with Coronavirus Disease 2019 (COVID-19) in January and February 2020 in China. Medical science monitor : international medical journal of experimental and clinical research. 2020;26:e923549.

4. Alsubaie S, Hani Temsah M, Al-Eyadhy AA, Gossady I, Hasan GM, Al-Rabiaah A, et al. Middle East Respiratory Syndrome Coronavirus epidemic impact on healthcare workers' risk perceptions, work and personal lives. Journal of infection in developing countries. 2019;13(10):920-6.

5. Bukhari EE, Temsah MH, Aleyadhy AA, Alrabiaa AA, Alhboob AA, Jamal AA, et al. Middle East respiratory syndrome coronavirus (MERS-CoV) outbreak perceptions of risk and stress evaluation in nurses. Journal of infection in developing countries. 2016;10(8):845-50.

6. Khalid I, Khalid TJ, Qabajah MR, Barnard AG, Qushmaq IA. Healthcare Workers Emotions, Perceived Stressors and Coping Strategies During a MERS-CoV Outbreak. Clinical medicine \& research. 2016;14(1):7-14.

7. Kim JS, Choi JS. Factors Influencing Emergency Nurses' Burnout During an Outbreak of Middle East Respiratory Syndrome Coronavirus in Korea. Asian nursing research. 2016;10(4):295-9. 8. Li L, Wan C, Ding R, Liu Y, Chen J, Wu Z, et al. Mental distress among Liberian medical staff working at the China Ebola Treatment Unit: a cross sectional study. Health and quality of life outcomes. 2015;13(101153626):156.

9. Austria-Corrales F, Cruz-Valdes B, Herrera-Kiengelher L, Vazquez-Garcia JC, SalasHernandez J. [Burnout syndrome among medical residents during the influenza A H1N1 sanitary contigency in Mexico]. Sindrome de burnout en medicos mexicanos en entrenamiento durante una contingencia sanitaria por virus de influenza A H1N1. 2011;147(2):97-103.

10. Goulia P, Mantas C, Dimitroula D, Mantis D, Hyphantis T. General hospital staff worries, perceived sufficiency of information and associated psychological distress during the A/H1N1 influenza pandemic. BMC infectious diseases. 2010;10(100968551):322.

11. Styra R, Hawryluck L, Robinson S, Kasapinovic S, Fones C, Gold WL. Impact on health care workers employed in high-risk areas during the Toronto SARS outbreak. Journal of psychosomatic research. 2008;64(2):177-83.

12. Loh L-C, Ali AM, Ang T-H, Chelliah A. Impact of a spreading epidemic on medical students. The Malaysian journal of medical sciences : MJMS. 2006;13(2):30-6.

13. Chan SS, Leung GM, Tiwari AF, Salili F, Leung SS, Wong DC, et al. The impact of workrelated risk on nurses during the SARS outbreak in Hong Kong. Family \& community health. 2005;28(3):274-87.

14. Grace SL, Hershenfield K, Robertson E, Stewart DE. The occupational and psychosocial impact of SARS on academic physicians in three affected hospitals. Psychosomatics. 2005;46(5):385-91.

15. Koh D, Lim MK, Chia SE, Ko SM, Qian F, Ng V, et al. Risk Perception and Impact of Severe Acute Respiratory Syndrome (SARS) on Work and Personal Lives of Healthcare Workers in Singapore: What Can We Learn? Medical Care. 2005;43(7):676-82.

16. Lee $\mathrm{S}-\mathrm{H}$, Juang $\mathrm{Y}-\mathrm{Y}$, Su Y-J, Lee $\mathrm{H}-\mathrm{L}$, Lin $\mathrm{Y}-\mathrm{H}$, Chao C-C. Facing SARS: psychological impacts on SARS team nurses and psychiatric services in a Taiwan general hospital. General hospital psychiatry. 2005;27(5):352-8. 
medRxiv preprint doi: https://doi.org/10.1101/2020.04.02.20048892; this version posted April 6, 2020. The copyright holder for this preprint (which was not certified by peer review) is the author/funder, who has granted medRxiv a license to display the preprint in perpetuity. It is made available under a CC-BY-ND 4.0 International license .

17. Tolomiczenko GS, Kahan M, Ricci M, Strathern L, Jeney C, Patterson K, et al. SARS: coping with the impact at a community hospital. Journal of advanced nursing. 2005;50(1):101-10.

18. Bai Y, Lin C-C, Lin C-Y, Chen J-Y, Chue C-M, Chou P. Survey of stress reactions among health care workers involved with the SARS outbreak. Psychiatric services (Washington, DC). 2004;55(9):1055-7.

19. Chan AOM, Huak CY. Psychological impact of the 2003 severe acute respiratory syndrome outbreak on health care workers in a medium size regional general hospital in Singapore. Occupational medicine (Oxford, England). 2004;54(3):190-6.

20. Maunder RG, Lancee WJ, Rourke S, Hunter JJ, Goldbloom D, Balderson K, et al. Factors associated with the psychological impact of severe acute respiratory syndrome on nurses and other hospital workers in Toronto. Psychosomatic medicine. 2004;66(6):938-42.

21. Nickell LA, Crighton EJ, Tracy CS, Al-Enazy H, Bolaji Y, Hanjrah S, et al. Psychosocial effects of SARS on hospital staff: survey of a large tertiary care institution. CMAJ : Canadian Medical Association journal = journal de l'Association medicale canadienne. 2004;170(5):793-8.

22. Poon E, Liu KS, Cheong DL, Lee CK, Yam LYC, Tang WN. Impact of severe respiratory syndrome on anxiety levels of front-line health care workers. Hong Kong medical journal = Xianggang yi xue za zhi. 2004;10(5):325-30.

23. Sim K, Chong PN, Chan YH, Soon WSW. Severe acute respiratory syndrome-related psychiatric and posttraumatic morbidities and coping responses in medical staff within a primary health care setting in Singapore. The Journal of clinical psychiatry. 2004;65(8):1120-7.

24. Lee SM, Kang WS, Cho A-R, Kim T, Park JK. Psychological impact of the 2015 MERS outbreak on hospital workers and quarantined hemodialysis patients. Comprehensive psychiatry. 2018;87:123-7.

25. Ji D, Ji Y-J, Duan X-Z, Li W-G, Sun Z-Q, Song X-A, et al. Prevalence of psychological symptoms among Ebola survivors and healthcare workers during the 2014-2015 Ebola outbreak in Sierra Leone: a cross-sectional study. Oncotarget. 2017;8(8):12784-91.

26. Su T-P, Lien T-C, Yang C-Y, Su YL, Wang J-H, Tsai S-L, et al. Prevalence of psychiatric morbidity and psychological adaptation of the nurses in a structured SARS caring unit during outbreak: a prospective and periodic assessment study in Taiwan. Journal of psychiatric research. 2007;41(1):119-30.

27. Chen C-S, Wu H-Y, Yang P, Yen C-F. Psychological Distress of Nurses in Taiwan Who Worked During the Outbreak of SARS. Psychiatric Services. 2005;56(1):76-9.

28. Park J-S, Lee E-H, Park N-R, Choi YH. Mental Health of Nurses Working at a Governmentdesignated Hospital During a MERS-CoV Outbreak: A Cross-sectional Study. Archives of psychiatric nursing. 2018;32(1):2-6.

29. Oh N, Hong N, Ryu DH, Bae SG, Kam S, Kim K-Y. Exploring Nursing Intention, Stress, and Professionalism in Response to Infectious Disease Emergencies: The Experience of Local Public Hospital Nurses During the 2015 MERS Outbreak in South Korea. Asian nursing research. 2017;11(3):230-6.

30. Tang L, Pan L, Yuan L, Zha L. Prevalence and related factors of post-traumatic stress disorder among medical staff members exposed to H7N9 patients. International journal of nursing sciences. 2017;4(1):63-7.

31. Lehmann M, Bruenahl CA, Addo MM, Becker S, Schmiedel S, Lohse AW, et al. Acute Ebola virus disease patient treatment and health-related quality of life in health care professionals: $A$ controlled study. Journal of psychosomatic research. 2016;83(376333):69-74.

32. Liu X, Kakade M, Fuller CJ, Fan B, Fang Y, Kong J, et al. Depression after exposure to stressful events: lessons learned from the severe acute respiratory syndrome epidemic. Comprehensive psychiatry. 2012;53(1):15-23.

33. Matsuishi K, Kawazoe A, Imai H, Ito A, Mouri K, Kitamura N, et al. Psychological impact of the pandemic (H1N1) 2009 on general hospital workers in Kobe. Psychiatry and clinical neurosciences. 2012;66(4):353-60. 
medRxiv preprint doi: https://doi.org/10.1101/2020.04.02.20048892; this version posted April 6, 2020. The copyright holder for this preprint (which was not certified by peer review) is the author/funder, who has granted medRxiv a license to display the preprint in perpetuity. It is made available under a CC-BY-ND 4.0 International license .

34. Lancee WJ, Maunder RG, Goldbloom DS. Prevalence of psychiatric disorders among Toronto hospital workers one to two years after the SARS outbreak. Psychiatric Services. 2008;59(1):91-5.

35. Wu P, Liu X, Fang Y, Fan B, Fuller CJ, Guan Z, et al. Alcohol abuse/dependence symptoms among hospital employees exposed to a SARS outbreak. Alcohol and alcoholism (Oxford, Oxfordshire). 2008;43(6):706-12.

36. Chen N-H, Wang P-C, Hsieh M-J, Huang C-C, Kao K-C, Chen $\mathrm{Y}-\mathrm{H}$, et al. Impact of severe acute respiratory syndrome care on the general health status of healthcare workers in taiwan. Infection control and hospital epidemiology. 2007;28(1):75-9.

37. Lin $\mathrm{C}-\mathrm{Y}$, Peng $\mathrm{Y}-\mathrm{C}, \mathrm{Wu} \mathrm{Y}-\mathrm{H}$, Chang J, Chan $\mathrm{C}-\mathrm{H}, \mathrm{Yang} \mathrm{D}-\mathrm{Y}$. The psychological effect of severe acute respiratory syndrome on emergency department staff. Emergency medicine journal : EMJ. 2007;24(1):12-7.

38. Marjanovic Z, Greenglass ER, Coffey S. The relevance of psychosocial variables and working conditions in predicting nurses' coping strategies during the SARS crisis: an online questionnaire survey. International journal of nursing studies. 2007;44(6):991-8.

39. Wong WC, Wong SY, Lee A, Goggins WB. How to provide an effective primary health care in fighting against severe acute respiratory syndrome: the experiences of two cities. American journal of infection control. 2007;35(1):50-5.

40. L. F, Z. M, E.R. G, S. C. Emotional exhaustion and state anger in nurses who worked during the sars outbreak: The role of perceived threat and organizational support. Can J Community Ment Health. 2006;25(2):89-103.

41. Lu Y-C, Shu B-C, Chang Y-Y, Lung F-W. The mental health of hospital workers dealing with severe acute respiratory syndrome. Psychotherapy and psychosomatics. 2006;75(6):370-5.

42. Maunder RG, Lancee WJ, Balderson KE, Bennett JP, Borgundvaag B, Evans S, et al. Longterm psychological and occupational effects of providing hospital healthcare during SARS outbreak. Emerging infectious diseases. 2006;12(12):1924-32.

43. Ho SMY, Kwong-Lo RSY, Mak CWY, Wong JS. Fear of severe acute respiratory syndrome (SARS) among health care workers. Journal of consulting and clinical psychology. 2005;73(2):344-9. 44. Phua DH, Tang HK, Tham KY. Coping responses of emergency physicians and nurses to the 2003 severe acute respiratory syndrome outbreak. Academic emergency medicine : official journal of the Society for Academic Emergency Medicine. 2005;12(4):322-8.

45. K.Y. T, Y.H. T, O.H. L, W.L. T, M.K. O, H.K. T. Psychological morbidity among emergency department doctors and nurses after the SARS outbreak. Hong Kong J Emerg Med. 2005;12(4):21523.

46. Wong TW, Yau JKY, Chan CLW, Kwong RSY, Ho SMY, Lau CC, et al. The psychological impact of severe acute respiratory syndrome outbreak on healthcare workers in emergency departments and how they cope. European journal of emergency medicine : official journal of the European Society for Emergency Medicine. 2005;12(1):13-8.

47. Chua SE, Cheung V, Cheung C, McAlonan GM, Wong JWS, Cheung EPT, et al. Psychological effects of the SARS outbreak in Hong Kong on high-risk health care workers. Canadian journal of psychiatry Revue canadienne de psychiatrie. 2004;49(6):391-3.

48. Tam CWC, Pang EPF, Lam LCW, Chiu HFK. Severe acute respiratory syndrome (SARS) in Hong Kong in 2003: stress and psychological impact among frontline healthcare workers.

Psychological medicine. 2004;34(7):1197-204.

49. Verma S, Mythily S, Chan YH, Deslypere JP, Teo EK, Chong SA. Post-SARS psychological morbidity and stigma among general practitioners and traditional Chinese medicine practitioners in Singapore. Annals of the Academy of Medicine, Singapore. 2004;33(6):743-8.

50. Wong WCW, Lee A, Tsang KK, Wong SYS. How did general practitioners protect themselves, their family, and staff during the SARS epidemic in Hong Kong? Journal of epidemiology and community health. 2004;58(3):180-5.

51. Brooks SK, Dunn R, Amlot R, Rubin GJ, Greenberg N. A Systematic, Thematic Review of Social and Occupational Factors Associated With Psychological Outcomes in Healthcare Employees 
medRxiv preprint doi: https://doi.org/10.1101/2020.04.02.20048892; this version posted April 6, 2020. The copyright holder for this preprint (which was not certified by peer review) is the author/funder, who has granted medRxiv a license to display the preprint in perpetuity. It is made available under a CC-BY-ND 4.0 International license .

During an Infectious Disease Outbreak. Journal of occupational and environmental medicine. 2018;60(3):248-57.

52. Lung F-W, Lu Y-C, Chang Y-Y, Shu B-C. Mental Symptoms in Different Health Professionals During the SARS Attack: A Follow-up Study. The Psychiatric quarterly. 2009;80(2):107-16.

53. Wu P, Fang Y, Guan Z, Fan B, Kong J, Yao Z, et al. The psychological impact of the SARS epidemic on hospital employees in China: Exposure, risk perception, and altruistic acceptance of risk. The Canadian Journal of Psychiatry / La Revue canadienne de psychiatrie. 2009;54(5):302-11. 54. McAlonan GM, Lee AM, Cheung V, Cheung C, Tsang KWT, Sham PC, et al. Immediate and sustained psychological impact of an emerging infectious disease outbreak on health care workers. Canadian journal of psychiatry Revue canadienne de psychiatrie. 2007;52(4):241-7.

55. Lee AM, Wong JGWS, McAlonan GM, Cheung V, Cheung C, Sham PC, et al. Stress and psychological distress among SARS survivors 1 year after the outbreak. Canadian journal of psychiatry Revue canadienne de psychiatrie. 2007;52(4):233-40.

56. Chong M-Y, Wang W-C, Hsieh W-C, Lee C-Y, Chiu N-M, Yeh W-C, et al. Psychological impact of severe acute respiratory syndrome on health workers in a tertiary hospital. The British journal of psychiatry : the journal of mental science. 2004;185(342367):127-33. 
medRxiv preprint doi: https://doi.org/10.1101/2020.04.02.20048892; this version posted April 6, 2020. The copyright holder for this preprint (which was not certified by peer review) is the author/funder, who has granted medRxiv a license to display the preprint in perpetuity.

It is made available under a CC-BY-ND 4.0 International license .

\section{Online Appendix 5. Forest plots}
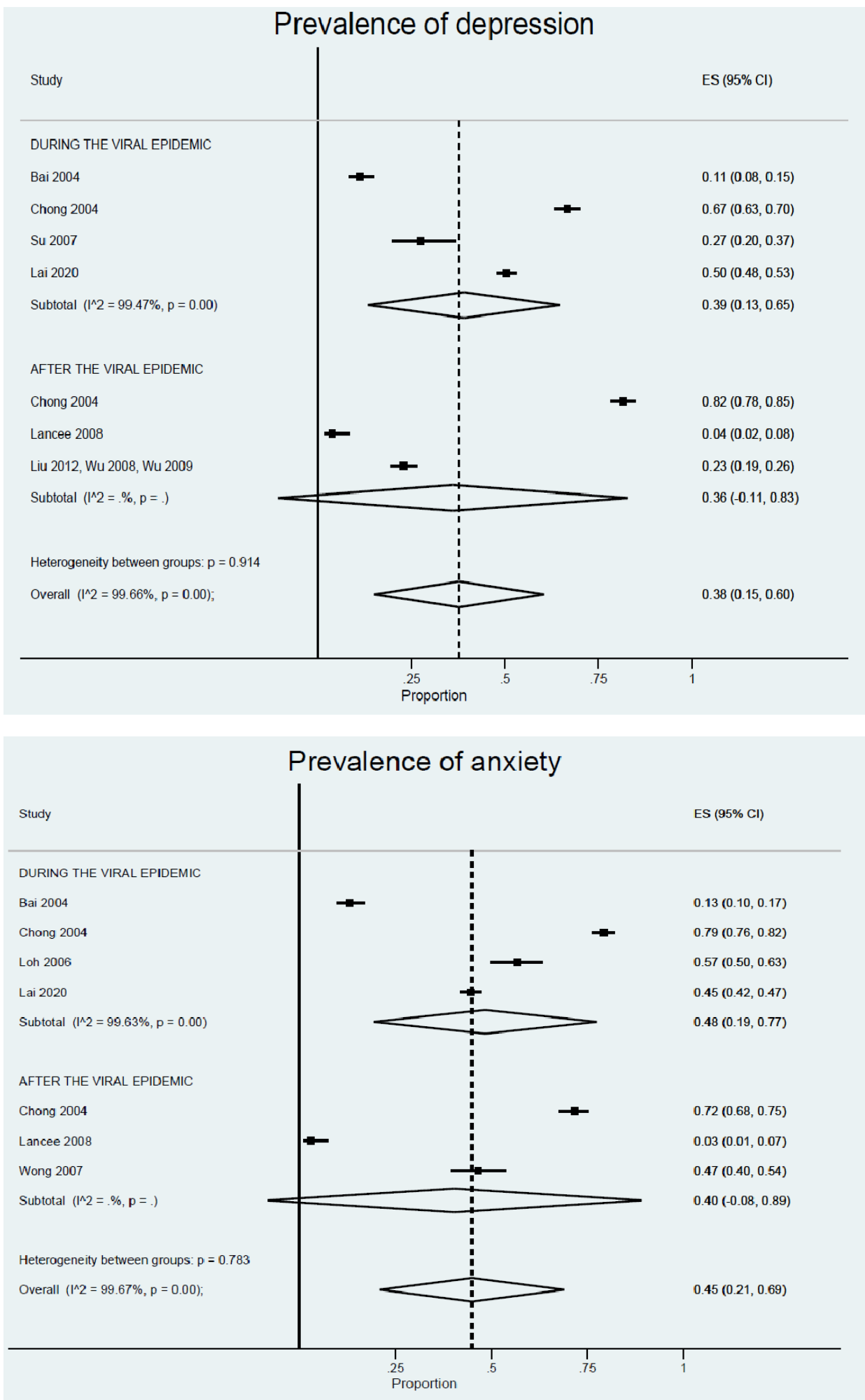
medRxiv preprint doi: https://doi.org/10.1101/2020.04.02.20048892; this version posted April 6, 2020. The copyright holder for this preprint (which was not certified by peer review) is the author/funder, who has granted medRxiv a license to display the preprint in perpetuity.

It is made available under a CC-BY-ND 4.0 International license .
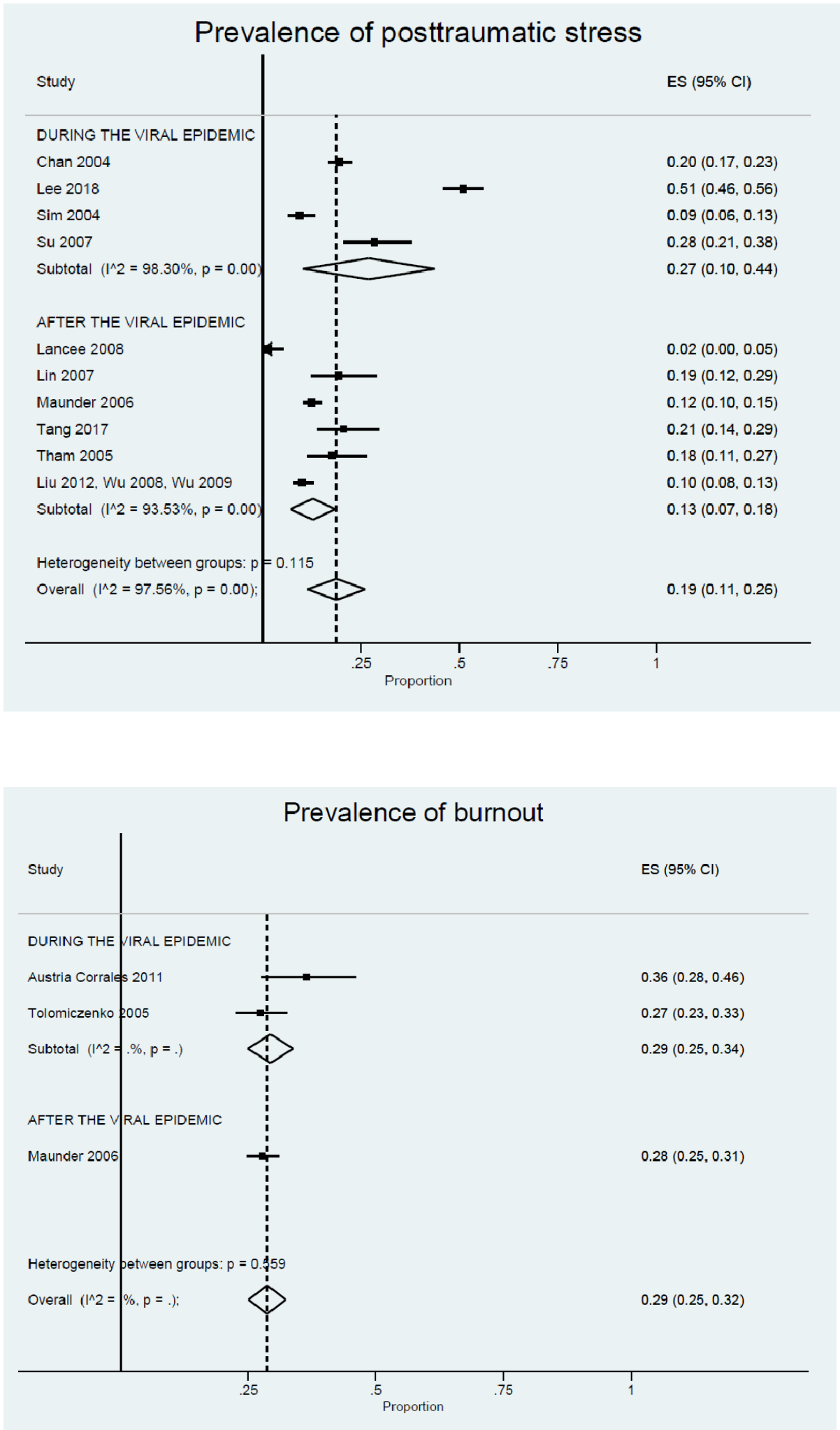
medRxiv preprint doi: https://doi.org/10.1101/2020.04.02.20048892; this version posted April 6, 2020. The copyright holder for this preprint (which was not certified by peer review) is the author/funder, who has granted medRxiv a license to display the preprint in perpetuity.

It is made available under a CC-BY-ND 4.0 International license.

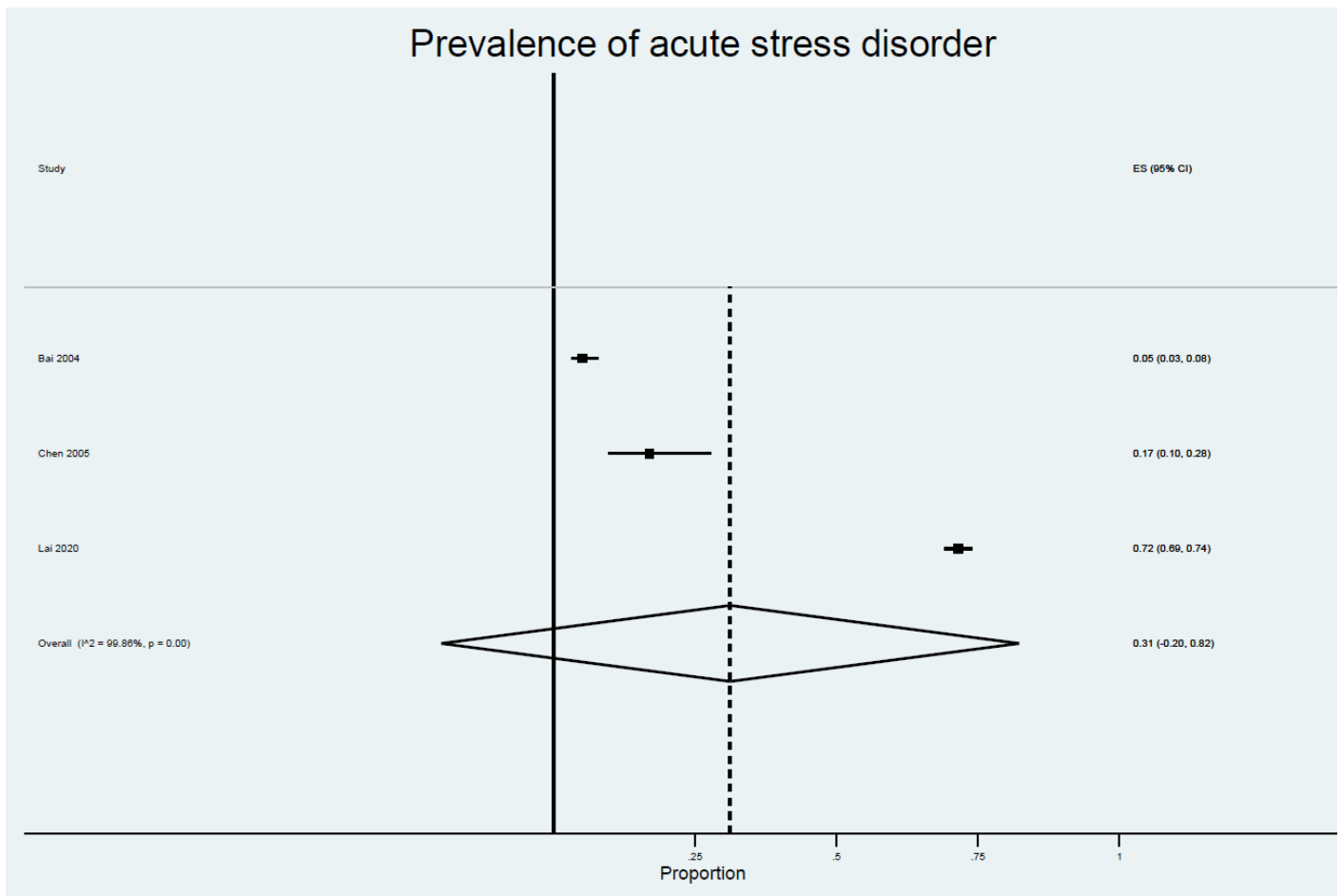


Online Appendix 6. Summary of Findings table of studies of interventions to reduce impact of epidemic outbreaks on mental health of healthcare professionals

\begin{tabular}{|c|c|c|c|c|}
\hline $\begin{array}{l}\text { Author/ } \\
\text { year/health } \\
\text { emergency/ } \\
\text { country/ }\end{array}$ & $\begin{array}{l}\text { Setting/ } \\
\text { Healthcare } \\
\text { professionals/ } \\
\text { Timing }\end{array}$ & $\begin{array}{l}\text { Design } \\
\mathrm{N} \\
\text { Mental health } \\
\text { area }\end{array}$ & Description of the intervention & Main results \\
\hline \multicolumn{5}{|c|}{ Educational interventions } \\
\hline $\begin{array}{l}\text { Aiello 2011(1)/ } \\
\text { SARS/ } \\
\text { Canada }\end{array}$ & $\begin{array}{l}\text { Hospital/ } \\
\text { HCWs/ } \\
\text { after the emergency }\end{array}$ & $\begin{array}{l}\text { cross-sectional/ } \\
\text { 1020/ } \\
\text { resilience }\end{array}$ & $\begin{array}{l}\text { Face to face group training session, based on } \\
\text { Folkman and Greer's model of coping. Content } \\
\text { included: stressors associated with pandemic } \\
\text { influenza (e.g., rapid spread of illness, rapidly } \\
\text { changing state of knowledge, personal and family } \\
\text { risk, social isolation); common concerns (e.g., family, } \\
\text { burden of job stress); normal responses to } \\
\text { extraordinary stress; evidence of the impact of SARS- } \\
\text { related stress on HCWs; organizational approaches } \\
\text { to building resilience and reducing stress; individual } \\
\text { approaches to coping and maintaining resilience; and } \\
\text { resources for further support. }\end{array}$ & $\begin{array}{l}\text { A high proportion of participants found the session } \\
\text { relevant to work life and personal life, useful, } \\
\text { helpful, and informative. While most participants } \\
\text { did not feel prepared to deal confidently with the } \\
\text { pandemic before the session ( } N=356 ; 35 \%) \text {, there } \\
\text { was a higher proportion of participants who felt } \\
\text { better able to cope after the session ( } N=776 ; 76 \%) \\
\text { (Statistically significant difference: } z=17.98 \text {, } \\
P=0.0020) \text {. }\end{array}$ \\
\hline $\begin{array}{l}\text { Maunder } \\
\text { 2010(2)/ } \\
\text { H1N1/ } \\
\text { Canada }\end{array}$ & $\begin{array}{l}\text { Hospital/ } \\
\text { HCWs/ } \\
\text { before the } \\
\text { emergency }\end{array}$ & $\begin{array}{l}\text { Uncontrolled } \\
\text { before-after } \\
\text { study / } \\
158 /\end{array}$ & $\begin{array}{l}\text { Computer-assisted resilience training to prepare } \\
\text { healthcare workers for pandemic influenza. The } \\
\text { participants were randomly assigned to the short ( } 7 \\
\text { sessions, median cumulative duration } 111 \text { minutes), } \\
\text { medium ( } 12 \text { sessions, } 158 \text { minutes) or long ( } 17\end{array}$ & $\begin{array}{l}\text { The course was associated with significant } \\
\text { improvements in confidence in support and } \\
\text { training }(P<0.0001) \text {, pandemic self-efficacy } \\
(P<0.0001) \text {, and interpersonal problems }(P<0.05 \text { for } \\
\text { seven out of the nine constructs examined). }\end{array}$ \\
\hline
\end{tabular}




\begin{tabular}{|c|c|c|c|c|}
\hline & & Stress & $\begin{array}{l}\text { sessions, } 223 \text { minutes) version. The course consisted } \\
\text { of modules incorporating different modalities of } \\
\text { learning. Knowledge-based modules addressed the } \\
\text { topics listed below using audio and video mini- } \\
\text { lectures accompanied by onscreen notes and printed } \\
\text { fact sheets. Quizzes and games provided brief } \\
\text { diversions and reinforced knowledge. Relaxation } \\
\text { skills were taught with audio modules guiding } \\
\text { participants in progressive muscle relaxation, } \\
\text { relaxation breathing, imagery, and combined } \\
\text { techniques. Self-assessment modules used } \\
\text { psychological questionnaires to characterize } \\
\text { interpersonal problem and coping style. Feedback } \\
\text { was provided that was both individualized and } \\
\text { relevant to the context. }\end{array}$ & $\begin{array}{l}\text { Comparison of doses showed improved } \\
\text { interpersonal problems in the medium and long } \\
\text { course but not in the short course. There was a } \\
\text { trend towards higher drop-out rates with longer } \\
\text { duration of training. }\end{array}$ \\
\hline \multicolumn{5}{|c|}{ Multifaceted interventions } \\
\hline $\begin{array}{l}\text { Chen } 2006(3) / \\
\text { SARS/ } \\
\text { Taiwan }\end{array}$ & $\begin{array}{l}\text { Hospital/ } \\
\text { Nurses/ } \\
\text { before, during, and } \\
\text { after the emergency }\end{array}$ & $\begin{array}{l}\text { Uncontrolled } \\
\text { before-after } \\
\text { study/ } \\
116 / \\
\text { Depression and } \\
\text { anxiety }\end{array}$ & $\begin{array}{l}\text { SARS prevention program, based on information } \\
\text { provided by WHO and Centers for Disease Control. } \\
\text { The program included in-service training, manpower } \\
\text { allocation, gathering sufficient protective equipment, } \\
\text { and establishment of a mental health team. In order } \\
\text { to guard against cross-infection in the hospital, } \\
\text { several measures were taken with regard to handling } \\
\text { procedure for SARS cases in general isolation room } \\
\text { that included space, staff preparation, and } \\
\text { environment. }\end{array}$ & $\begin{array}{l}\text { Statistically significant }(\mathrm{P}<0.05) \text { improvements } \\
\text { observed in nursing staff's anxiety and depression } \\
\text { along with sleep quality after } 2 \text { weeks of the } \\
\text { initiation of the SARS prevention program. }\end{array}$ \\
\hline $\begin{array}{l}\text { Schreiber } \\
\text { 2019(4)/ } \\
\text { Ebola/ }\end{array}$ & Unclear/ & $\begin{array}{l}\text { Cross-sectional/ } \\
45 /\end{array}$ & $\begin{array}{l}\text { The Anticipate, Plan and Deter (APD) Responder Risk } \\
\text { and Resilience Model was designed to maximize the } \\
\text { resilience of HCWs. The intervention includes pre- } \\
\text { deployment development of an individualized }\end{array}$ & $\begin{array}{l}\text { Impact of the intervention not described. Authors } \\
\text { report case examples of the APD model }\end{array}$ \\
\hline
\end{tabular}




\begin{tabular}{|l|l|l|l|l|}
\hline $\begin{array}{l}\text { USA, } \\
\text { Philippines \& } \\
\text { West Africa } \\
\text { during, and after the } \\
\text { emergency }\end{array}$ & PTSD & $\begin{array}{l}\text { resilience plan and an in-theatre, real-time self-triage } \\
\text { system, which together allow HCWs to assess and } \\
\text { manage the full range of psychological risk and } \\
\text { resilience for themselves and their families. It } \\
\text { includes objective mental health risk factors to } \\
\text { prompt activation of a coping plan, in connection } \\
\text { with unit leadership real-time situational awareness } \\
\text { to address responder risk early before PTSD and } \\
\text { impairment become established. }\end{array}$ & $\begin{array}{l}\text { implemention, but empirical data concerning its } \\
\text { impact is not provided. }\end{array}$ \\
\hline \begin{tabular}{l|l|l|l|} 
SARS/ \\
Shychotherapy interventions $2004(5) /$
\end{tabular} & $\begin{array}{l}\text { Hospital/ } \\
\text { Surses/ }\end{array}$ & $\begin{array}{l}\text { Cross-sectional/ } \\
\text { during the } \\
\text { emergency }\end{array}$ & $\begin{array}{l}\text { Psychological support group sessions (not based on } \\
\text { any specific psychotherapeutic model). The } \\
\text { scheduled period of time for each session was } \\
\text { around 75 min. The primary goal of therapy was to } \\
\text { externalize all emotions, and bring support to each } \\
\text { other. All participants were committed to overcome } \\
\text { issues encouraging one another to express their } \\
\text { emotions. }\end{array}$ & $\begin{array}{l}\text { Impact of the intervention per se not reported. } \\
\text { Instead, the authors describe the psychological } \\
\text { reactions experienced by the nurses to the } \\
\text { emergency. At the beginning of the outbreak the } \\
\text { nurses experienced dynamic development of } \\
\text { specific behaviours (fear, anger, and blame). After } \\
\text { the outbreak the participants developed a } \\
\text { significant sense of grief and frustration after } \\
\text { specific events such as the death of a colleague. }\end{array}$ \\
\hline
\end{tabular}

H1N1= H1N1 influenza virus; HCWs= health care workers; N= sample size; PTSD= Post-Traumatic Stress Disorder; SARS= severe acute respiratory syndrome; $\mathrm{WHO}=$ World Health Organization. 
medRxiv preprint doi: https://doi.org/10.1101/2020.04.02.20048892; this version posted April 6, 2020. The copyright holder for this preprint (which was not certified by peer review) is the author/funder, who has granted medRxiv a license to display the preprint in perpetuity. It is made available under a CC-BY-ND 4.0 International license .

\section{REFERENCES}

1. Aiello A, Khayeri MY-E, Raja S, Peladeau N, Romano D, Leszcz M, et al. Resilience training for hospital workers in anticipation of an influenza pandemic. The Journal of continuing education in the health professions. 2011;31(1):15-20.

2. Maunder RG, Lancee WJ, Mae R, Vincent L, Peladeau N, Beduz MA, et al. Computerassisted resilience training to prepare healthcare workers for pandemic influenza: a randomized trial of the optimal dose of training. BMC health services research. 2010;10(101088677):72. 3. Chen R, Chou K-R, Huang Y-J, Wang T-S, Liu S-Y, Ho L-Y. Effects of a SARS prevention programme in Taiwan on nursing staff's anxiety, depression and sleep quality: a longitudinal survey. International journal of nursing studies. 2006;43(2):215-25.

4. Schreiber M, Cates DS, Formanski S, King M. Maximizing the Resilience of Healthcare Workers in Multi-hazard Events: Lessons from the 2014-2015 Ebola Response in Africa. Military medicine. 2019;184:114-20.

5. Kwek Seow Khee, Low Bee Lee, Ong Thiew Chai, Chan Keen Loong, Chew Wuen Ming, Tang Hui Kheng. The psychological impact of SARS on health care providers. Crit Care Shock. 2004;7(2):99-106. 
Online Appendix 7. Evidence profiles of the certainty of evidence concerning interventions for preventing the psychological impact of infectious epidemic outbreaks in healthcare workers

Evidence profile 1: Educational interventions compared to usual care for preventing the psychological impact of infectious epidemic outbreaks in healthcare workers

\begin{tabular}{|c|c|c|c|c|c|c|c|c|}
\hline \multicolumn{7}{|c|}{ Certainty assessment } & \multirow{2}{*}{ Impact } & \multirow{2}{*}{ Certainty } \\
\hline $\begin{array}{c}\text { № of } \\
\text { studies }\end{array}$ & Study design & $\begin{array}{l}\text { Risk of } \\
\text { bias }\end{array}$ & Inconsistency & Indirectness & Imprecision & $\begin{array}{c}\text { Other } \\
\text { considerations }\end{array}$ & & \\
\hline \multicolumn{9}{|c|}{ Confidence in support and training } \\
\hline $1(1)$ & $\begin{array}{c}\text { observational } \\
\text { studies }\end{array}$ & $\begin{array}{c}\text { very } \\
\text { serious } \\
\text { a }\end{array}$ & not serious & not serious & not serious & none & $\begin{array}{l}\text { Confidence in training and support was measured with a } \\
\text { questionnaire derived to measure responses of healthcare workers } \\
\text { to SARS that was found to predict long-term effects of SARS, } \\
\text { modified to apply to influenza. Nine items (e.g. "If I have problems } \\
\text { using equipment in an influenza pandemic, I am confident that I will } \\
\text { have someone to ask for help") are rated on a } 5 \text {-point scale from } 1 \\
\text { (strongly disagree) to } 5 \text { (strongly agree). Summed item scores were } \\
\text { normally distributed. Cronbach's alpha was } 0.85 \text { Participants } \\
\text { showed significant improvements from the start to the end of the } \\
\text { course in confidence in training and support: mean [sd] pre vs. post } \\
\text { intervention }=32.6[4.9] \text { vs } 33.8 \text { [4.7]; }<0.001 \text {. }\end{array}$ & $\begin{array}{c}\oplus \bigcirc \bigcirc \bigcirc \\
\text { VERY } \\
\text { LOW }\end{array}$ \\
\hline
\end{tabular}




\begin{tabular}{|c|c|c|c|c|c|c|c|c|}
\hline \multicolumn{7}{|c|}{ Certainty assessment } & \multirow{2}{*}{ Impact } & \multirow{2}{*}{ Certainty } \\
\hline $\begin{array}{l}\text { № of } \\
\text { studies }\end{array}$ & Study design & $\begin{array}{l}\text { Risk of } \\
\text { bias }\end{array}$ & Inconsistency & Indirectness & Imprecision & $\begin{array}{c}\text { Other } \\
\text { considerations }\end{array}$ & & \\
\hline $2(1,2)$ & $\begin{array}{l}\text { observational } \\
\text { studies }\end{array}$ & $\begin{array}{c}\text { very } \\
\text { serious } \\
a, b\end{array}$ & not serious & not serious & not serious & none & $\begin{array}{l}\text { Maunder et al. } 2010 \text { measured perceived efficacy to adapt to } \\
\text { pandemic conditions using the Pandemic Self-Efficacy Scale } \\
\text { (authored for this study). This } 24 \text {-item scale measures attitudes } \\
\text { toward working in a pandemic (e.g. "How confident are you now } \\
\text { that in the event of an influenza pandemic you will be able to do } \\
\text { your job effectively, even if you are stressed or tired?") rated on a 5- } \\
\text { point scale from } 1 \text { (Not confident at all. I don't think I can do this) to } \\
5 \text { (Very confident. I am sure of it). Scores were normally distributed. } \\
\text { Cronbach's alpha was } 0.93 \text {. Participants showed significant } \\
\text { improvements from the start to the end of the course in pandemic } \\
\text { self-efficacy: mean [sd] pre vs. post intervention = } 87.7 \text { [12.6] vs } \\
92.9[12.9] ;<0.001 . \\
\text { Aiello et al. } 2011 \text { measured perceived efficacy based on two } \\
\text { questions ("Prior to the session, I felt prepared to deal confidently } \\
\text { with the situations that I might face in the event of a pandemic", } \\
\text { and "Following today's session, I believe that I will be better able to } \\
\text { cope in the event of a pandemic") rated on a } 5 \text {-point agreement } \\
\text { scale. While most participants did not feel prepared to deal } \\
\text { confidently with the pandemic before the session (35\%), there was a } \\
\text { higher proportion of participants who felt better able to cope after } \\
\text { the session (76\%). This difference was statistically significant ( } z= \\
17.98, p=0.0020 \text {.) }\end{array}$ & $\begin{array}{c}\oplus \bigcirc \bigcirc \bigcirc \\
\text { VERY } \\
\text { LOW }\end{array}$ \\
\hline
\end{tabular}




\begin{tabular}{|c|c|c|c|c|c|c|c|c|}
\hline \multicolumn{7}{|c|}{ Certainty assessment } & \multirow{2}{*}{ Impact } & \multirow[b]{2}{*}{ Certainty } \\
\hline $\begin{array}{l}\text { № of } \\
\text { studies }\end{array}$ & Study design & $\begin{array}{c}\text { Risk of } \\
\text { bias }\end{array}$ & Inconsistency & Indirectness & Imprecision & $\begin{array}{c}\text { Other } \\
\text { considerations }\end{array}$ & & \\
\hline $1(2)$ & $\begin{array}{c}\text { observational } \\
\text { studies }\end{array}$ & $\begin{array}{c}\text { very } \\
\text { serious } \\
\text { a }\end{array}$ & not serious & not serious & not serious & none & $\begin{array}{l}\text { Coping via problem-solving, seeking support from others and } \\
\text { escape-avoidance were measured with subscales of the Ways of } \\
\text { Coping Inventory an instrument which yields eight subscales of } \\
\text { coping strategies. In this study coping scales were selected that have } \\
\text { predictive power with respect to longterm stress-related outcomes } \\
\text { of working during the SARS outbreak. Coping scales were calculated } \\
\text { as the mean of item scores on a } 4 \text { point scale from } 0 \text { ("Not used") to } \\
4 \text { ("Used a great deal"). Problem-solving and seeking support were } \\
\text { both normally distributed. Cronbach's alpha was } 0.76 \text { for problem- } \\
\text { solving and } 0.77 \text { for seeking support. Escape-avoidance was skewed } \\
\text { toward zero. Cronbach's alpha } 0.73 \text {. Coping with stress using } \\
\text { problem-solving, seeking support from others or through escape- } \\
\text { avoidance did not change over the course. }\end{array}$ & $\begin{array}{c}\oplus \bigcirc \bigcirc \bigcirc \\
\text { VERY } \\
\text { LOW }\end{array}$ \\
\hline $1(2)$ & $\begin{array}{c}\text { observational } \\
\text { studies }\end{array}$ & $\begin{array}{c}\text { very } \\
\text { serious } \\
\text { a }\end{array}$ & not serious & not serious & not serious & $\begin{array}{c}\text { dose response } \\
\text { gradient }\end{array}$ & $\begin{array}{l}\text { Interpersonal problems were measured with the 32-item Inventory } \\
\text { of Interpersonal Problems (IIP-32), an abbreviated version of the IIP- } \\
64 \text {. Participants rate the degree to which they experience } \\
\text { interpersonal problems on a 5-point scale from } 0 \text { (not at all) to } 4 \\
\text { (extremely). Each of the eight subscales of the IIP (Controlling, Self- } \\
\text { Centered, Cold/Distant, Socially Inhibited, Nonassertive, Overly } \\
\text { Accommodating, Self-Sacrificing, and Intrusive/ Needy) are } \\
\text { calculated as the mean of } 4 \text { items. Cronbach's alpha was } 0.90 \text {. } \\
\text { Participants showed significant improvements from the start to the } \\
\text { end of the course in interpersonal problems overall score: mean [sd] } \\
\text { pre vs. post intervention = } 31.4 \text { [16.0] vs } 27.6[15.6] ;<0.001 \text {. }\end{array}$ & $\begin{array}{c}\oplus \bigcirc \bigcirc \bigcirc \\
\text { VERY } \\
\text { LOW }\end{array}$ \\
\hline
\end{tabular}


Cl: Confidence interval. a. Maunder et al. 2010 presents critical risk of bias due to potential bias due to confounding (no adjusted analysis of confounding factors), Proportions of missing participants differ substantially across interventions

(attrition was $12 \%$ in short courses and $28 \%$ in long courses.) The authors state an intention to treat analysis in the

methods, but no results were provided. b. Aiello et al 2011 presents serious risk of bias due the use of not validated

survey instruments, and unclear reporting of the method used to estimate the pre-post change in self-efficacy. 
Evidence profile 2. Multifaceted interventions compared to usual care for reducing the psychological impact during infectious epidemic outbreaks in healthcare workers

\begin{tabular}{|c|c|c|c|c|c|c|c|c|}
\hline \multicolumn{7}{|c|}{ Certainty assessment } & \multirow{2}{*}{ Impact } & \multirow{2}{*}{ Certainty } \\
\hline $\begin{array}{l}\text { № of } \\
\text { studies }\end{array}$ & Study design & $\begin{array}{l}\text { Risk of } \\
\text { bias }\end{array}$ & Inconsistency & Indirectness & Imprecision & $\begin{array}{c}\text { Other } \\
\text { considerations }\end{array}$ & & \\
\hline \multicolumn{9}{|l|}{ Anxiety } \\
\hline $1(3)$ & $\begin{array}{l}\text { observational } \\
\text { studies }\end{array}$ & $\begin{array}{c}\text { serious } \\
\text { a }\end{array}$ & not serious & not serious & not serious & none & $\begin{array}{l}\text { Anxiety was measured with Zung's self-rating anxiety scale (SAS). After } \\
\text { implementation of the SARS prevention program, the mean scores of anxiety } \\
\text { level decreased with time. The mean score from the first questionnaire before } \\
\text { caring for SARS patients is } 60 \text { points (SD=9.28), indicating moderate anxiety } \\
\text { compared to the mean scores of after the implementation of the anti-SARS } \\
\text { program, the mean scores of } 51,50 \text {, and } 46 \text { indicating mild anxiety, mild } \\
\text { anxiety, no anxiety, respectively, at the remaining time points. GEE models } \\
\text { showed that anxiety levels } 2 \text { weeks after the implementation of the prevention } \\
\text { program and while caring for SARS patients were significantly lower than } \\
\text { anxiety level before caring for SARS patients ( } p=0: 075 \text { ). The anxiety level } \\
\text { month after caring for SARS patients was also significantly lower than the } \\
\text { anxiety levels before care of SARS patients ( } p<0: 0001 \text { ). After caring for SARS } \\
\text { patients for } 3 \text { months and } 1 \text { month after the hospital returned to normal } \\
\text { operations, nursing personnel exhibited anxiety levels significantly lower than } \\
\text { that prior to caring for SARS patients ( }(p<0: 0001 \text { ). }\end{array}$ & $\begin{array}{c}\oplus \bigcirc \bigcirc \bigcirc \\
\text { VERY } \\
\text { LOW }\end{array}$ \\
\hline
\end{tabular}




\begin{tabular}{|c|c|c|c|c|c|c|c|c|}
\hline \multicolumn{7}{|c|}{ Certainty assessment } & \multirow{2}{*}{ Impact } & \multirow[b]{2}{*}{ Certainty } \\
\hline $\begin{array}{l}\text { № of } \\
\text { studies }\end{array}$ & Study design & $\begin{array}{c}\text { Risk of } \\
\text { bias }\end{array}$ & Inconsistency & Indirectness & Imprecision & $\begin{array}{c}\text { Other } \\
\text { considerations }\end{array}$ & & \\
\hline $1(3)$ & $\begin{array}{c}\text { observational } \\
\text { studies }\end{array}$ & $\begin{array}{c}\text { serious } \\
\text { a }\end{array}$ & not serious & not serious & not serious & none & $\begin{array}{l}\text { Depression was measured with Zung's self-rating depression scale (SDS). After } \\
\text { the implementation of the SARS prevention program, mean scores of } \\
\text { depression level decreased with time. At the time of the first questionnaire } \\
\text { before care of SARS patients began, the mean score was } 61 \text { points (SD =12.62), } \\
\text { indicating moderate depression. After program initiation, the mean scores of } \\
51,50 \text {, and } 48 \text { points indicated mild depression, mild depression, and no } \\
\text { depression, respectively. Using GEE, the levels of depression } 2 \text { weeks after } \\
\text { initiation of the SARS prevention program and while caring for SARS patients } \\
\text { were significantly lower than the level before caring for SARS patients } \\
\text { ( } p<0: 0001) \text {. At } 1 \text { month after caring for SARS patients, the level of depression } \\
\text { was also significantly lower than the levels of depression levels before the staff } \\
\text { began to care for SARS patients ( } p<0: 0001) \text {. After the hospital had returned to } \\
\text { normal operations, the level of depression was significantly lower than that } \\
\text { prior to taking care of SARS patients }(p<0: 0001) \text {. }\end{array}$ & $\begin{array}{c}\oplus \bigcirc \bigcirc \bigcirc \\
\text { VERY } \\
\text { LOW }\end{array}$ \\
\hline \multicolumn{9}{|c|}{ Sleep quality } \\
\hline $1(3)$ & $\begin{array}{c}\text { observational } \\
\text { studies }\end{array}$ & $\begin{array}{c}\text { serious } \\
\mathrm{a}\end{array}$ & not serious & not serious & not serious & none & $\begin{array}{l}\text { Sleep quality was measured with the Pittsburgh sleep quality index. The mean } \\
\text { score from the first questionnaire was } 12 \text { points }(S D=3.83) \text {, meaning that sleep } \\
\text { quality was poor. Of the remaining three questionnaires, the mean scores were } \\
10,10 \text {, and } 8 \text { indicating poor sleep quality. GEE showed that the mean score at } \\
2 \text { weeks after the SARS prevention program began when the staff was caring } \\
\text { for SARS patients was significantly lower than the mean score before they } \\
\text { began caring for SARS patients }(p=0.0053) \text {. At } 1 \text { month after caring for SARS } \\
\text { patients and at } 1 \text { month after the hospital resumed normal operations, the } \\
\text { mean score }(p=0: 0017) \text { was also significantly lower than the score before the } \\
\text { nursing care began }(p=0: 0008) \text {. }\end{array}$ & $\begin{array}{c}\oplus \bigcirc \bigcirc \bigcirc \\
\text { VERY } \\
\text { LOW }\end{array}$ \\
\hline
\end{tabular}




\section{REFERENCES}

1. Aiello A, Khayeri MY-E, Raja S, Peladeau N, Romano D, Leszcz M, et al. Resilience training for hospital workers in anticipation of an influenza pandemic. The Journal of continuing education in the health professions. 2011;31(1):15-20.

2. Maunder RG, Lancee WJ, Mae R, Vincent L, Peladeau N, Beduz MA, et al. Computerassisted resilience training to prepare healthcare workers for pandemic influenza: a randomized trial of the optimal dose of training. BMC health services research. 2010;10(101088677):72.

3. Chen R, Chou K-R, Huang Y-J, Wang T-S, Liu S-Y, Ho L-Y. Effects of a SARS prevention programme in Taiwan on nursing staff's anxiety, depression and sleep quality: a longitudinal survey. International journal of nursing studies. 2006;43(2):215-25. 


\section{Online Appendix 8. PRISMA checklist}

\begin{tabular}{|c|c|c|c|c|}
\hline Section/topic & $\#$ & Checklist item & & $\begin{array}{l}\text { Reported } \\
\text { on page \# }\end{array}$ \\
\hline \multicolumn{5}{|l|}{ TITLE } \\
\hline Title & 1 & $\begin{array}{l}\text { Identify the report as a systematic review, } \\
\text { meta-analysis, or both. }\end{array}$ & $\begin{array}{l}\text { IMPACT OF VIRAL EPIDEMIC OUTBREAKS ON MENTAL HEALTH OF HEALTHCARE } \\
\text { WORKERS: A RAPID SYSTEMATIC REVIEW }\end{array}$ & Page 1 \\
\hline \multicolumn{5}{|l|}{ ABSTRACT } \\
\hline Structured summary & 2 & $\begin{array}{l}\text { Provide a structured summary including, } \\
\text { as applicable: background; objectives; data } \\
\text { sources; study eligibility criteria, } \\
\text { participants, and interventions; study } \\
\text { appraisal and synthesis methods; results; } \\
\text { limitations; conclusions and implications of } \\
\text { key findings; systematic review } \\
\text { registration number. }\end{array}$ & $\begin{array}{l}\text { We have provided all the items, except Background, limitations and Systematic review } \\
\text { registration number. There is a summary box with the Implications of key findings. }\end{array}$ & Page 3 \\
\hline \multicolumn{5}{|l|}{ INTRODUCTION } \\
\hline Rationale & 3 & $\begin{array}{l}\text { Describe the rationale for the review in } \\
\text { the context of what is already known. }\end{array}$ & $\begin{array}{l}\text { To date, the impact of viral disease outbreaks on specific mental health problems and } \\
\text { the effectiveness of interventions to ameliorate such impact have not been } \\
\text { systematically reported. }\end{array}$ & Page 5 \\
\hline Objectives & 4 & $\begin{array}{l}\text { Provide an explicit statement of questions } \\
\text { being addressed with reference to } \\
\text { participants, interventions, comparisons, } \\
\text { outcomes, and study design (PICOS). }\end{array}$ & $\begin{array}{l}\text { The aim of this rapid systematic literature review is twofold: i) to examine the impact of } \\
\text { health emergencies caused by a viral pandemic or epidemic on HCWs mental health; } \\
\text { and ii) to assess the effectiveness of interventions to reduce such impact. }\end{array}$ & Page 5 \\
\hline \multicolumn{5}{|l|}{ METHODS } \\
\hline $\begin{array}{l}\text { Protocol and } \\
\text { registration }\end{array}$ & 5 & $\begin{array}{l}\text { Indicate if a review protocol exists, if and } \\
\text { where it can be accessed (e.g., Web } \\
\text { address), and, if available, provide }\end{array}$ & $\begin{array}{l}\text { There is no review protocol, as it is a rapid systematic review, in the current context of } \\
\text { the Covid-19 pandemic. }\end{array}$ & N/A \\
\hline
\end{tabular}




\begin{tabular}{|c|c|c|c|c|}
\hline & & $\begin{array}{l}\text { registration information including } \\
\text { registration number. }\end{array}$ & & \\
\hline Eligibility criteria & 6 & $\begin{array}{l}\text { Specify study characteristics (e.g., PICOS, } \\
\text { length of follow-up) and report } \\
\text { characteristics (e.g., years considered, } \\
\text { language, publication status) used as } \\
\text { criteria for eligibility, giving rationale. }\end{array}$ & Study and report characteristics are fully explained in the text. & Page 6 \\
\hline Information sources & 7 & $\begin{array}{l}\text { Describe all information sources (e.g., } \\
\text { databases with dates of coverage, contact } \\
\text { with study authors to identify additional } \\
\text { studies) in the search and date last } \\
\text { searched. }\end{array}$ & $\begin{array}{l}\text { We designed specific search strategies for biomedical databases (MEDLINE/Ovid, } \\
\text { EMBASE/Elsevier, and PsycInfo/EBSCO), combining MeSH terms and free-text keywords }\end{array}$ & $\begin{array}{l}\text { (Online } \\
\text { Appendix } \\
\text { 1) }\end{array}$ \\
\hline Search & 8 & $\begin{array}{l}\text { Present full electronic search strategy for } \\
\text { at least one database, including any limits } \\
\text { used, such that it could be repeated. }\end{array}$ & A fully explanation of electronic search strategy is provided. & $\begin{array}{l}\text { (Online } \\
\text { Appendix } \\
\text { 1) }\end{array}$ \\
\hline Study selection & 9 & $\begin{array}{l}\text { State the process for selecting studies (i.e., } \\
\text { screening, eligibility, included in } \\
\text { systematic review, and, if applicable, } \\
\text { included in the meta-analysis). }\end{array}$ & $\begin{array}{l}\text { We included empirical studies examining the impact on mental health of epidemic } \\
\text { outbreaks on HCWs, and studies about interventions to reduce such impact. We } \\
\text { included observational (cross-sectional, case-control, and cohort studies), and } \\
\text { experimental studies (non-controlled before-after studies, controlled before-after } \\
\text { studies, non-randomised controlled trials, and randomised controlled trials) according } \\
\text { to the taxonomy of study designs proposed by Cochrane Effective Practice and } \\
\text { Organisation of Care. } \\
\text { We included studies on any type of health emergency caused by a viral epidemic or } \\
\text { pandemic, and examining its impact on HCWs mental health during or after the crisis. } \\
\text { For intervention studies, we included also those that examined the impact of the } \\
\text { intervention on mental health problems (or their determinants) prior to the outbreak } \\
\text { onset. All types of settings and healthcare professionals were accepted for inclusion. } \\
\text { We included studies measuring any type of mental health problem or psychiatric } \\
\text { morbidity. We excluded narrative reviews, thesis, editorials, protocols, letters to the } \\
\text { editor, and studies not published in English, Spanish or Portuguese. }\end{array}$ & Page 6 \\
\hline
\end{tabular}




\begin{tabular}{|c|c|c|c|c|}
\hline $\begin{array}{l}\text { Data collection } \\
\text { process }\end{array}$ & 10 & $\begin{array}{l}\text { Describe method of data extraction from } \\
\text { reports (e.g., piloted forms, } \\
\text { independently, in duplicate) and any } \\
\text { processes for obtaining and confirming } \\
\text { data from investigators. }\end{array}$ & $\begin{array}{l}\text { One reviewer screened the retrieved references on title and abstract against the } \\
\text { selection criteria. Two reviewers (of those aforementioned) independently and blinded } \\
\text { against the others' judgements assessed full-text eligibility. Disagreements were solved } \\
\text { by consensus or by involving a third reviewer, if needed. }\end{array}$ & Page 7 \\
\hline Data items & 11 & $\begin{array}{l}\text { List and define all variables for which data } \\
\text { were sought (e.g., PICOS, funding sources) } \\
\text { and any assumptions and simplifications } \\
\text { made. }\end{array}$ & $\begin{array}{l}\text { We included studies on any type of health emergency caused by a viral epidemic or } \\
\text { pandemic, and examining its impact on HCWs mental health during or after the crisis, } \\
\text { and for intervention studies, we included also those that examined the impact of the } \\
\text { intervention on mental health problems (or their determinants) prior to the outbreak } \\
\text { onset. All types of settings and healthcare professionals were accepted for inclusion. } \\
\text { We included studies measuring any type of mental health problem or psychiatric } \\
\text { morbidity. }\end{array}$ & Page 7 \\
\hline $\begin{array}{l}\text { Risk of bias in } \\
\text { individual studies }\end{array}$ & 12 & $\begin{array}{l}\text { Describe methods used for assessing risk } \\
\text { of bias of individual studies (including } \\
\text { specification of whether this was done at } \\
\text { the study or outcome level), and how this } \\
\text { information is to be used in any data } \\
\text { synthesis. }\end{array}$ & $\begin{array}{l}\text { We assessed the risk of bias of observational studies (i.e., cross-sectional, case-control, } \\
\text { and cohort studies) by using the set of tools developed by Evidence Partners (McMaster } \\
\text { University); whereas ROBINS I was applied to uncontrolled trials, and AMSTAR for } \\
\text { systematic reviews. } \\
\text { One reviewer extracted all the data and assessed the risk of bias, while a second } \\
\text { reviewer cross-checked the information for accuracy and completeness. }\end{array}$ & Page 7 \\
\hline Summary measures & 13 & $\begin{array}{l}\text { State the principal summary measures } \\
\text { (e.g., risk ratio, difference in means). }\end{array}$ & $\begin{array}{l}\text { For studies about the impact of outbreaks on mental health, we conducted random- } \\
\text { effects meta-analyses to estimate the prevalence and } 95 \% \text { confidence interval (CI) of } \\
\text { each type of mental health condition, using the STATA command "metaprop". }\end{array}$ & Page 7 \\
\hline Synthesis of results & 14 & $\begin{array}{l}\text { Describe the methods of handling data } \\
\text { and combining results of studies, if done, } \\
\text { including measures of consistency (e.g., } I^{2} \text { ) } \\
\text { for each meta-analysis. }\end{array}$ & $\begin{array}{l}\text { We conducted subgroup analyses to explore potential differences in the prevalence of } \\
\text { mental health disorders during vs. after the outbreak. Heterogeneity was quantified by } \\
\text { the } 12 \text { statistic, where } 12>50 \% \text { was deemed as substantial heterogeneity. Publication } \\
\text { bias was examined with funnel plots and presence of asymmetry tested with Begg and } \\
\text { Egger tests. We used Stata, version } 12.0 \text { to conduct meta-analyses. }\end{array}$ & Page 7 \\
\hline Section/topic & $\#$ & Checklist item & & $\begin{array}{l}\text { Reported } \\
\text { on page \# }\end{array}$ \\
\hline $\begin{array}{l}\text { Risk of bias across } \\
\text { studies }\end{array}$ & 15 & $\begin{array}{l}\text { Specify any assessment of risk of bias that } \\
\text { may affect the cumulative evidence (e.g., }\end{array}$ & $\begin{array}{l}\text { We used the GRADE approach to assess the quality of evidence related to the outcomes } \\
\text { included in this rapid review. We used GRADEpro } 2011 \text { software to create 'Summary of }\end{array}$ & Page 8 \\
\hline
\end{tabular}




\begin{tabular}{|c|c|c|c|c|}
\hline & & $\begin{array}{l}\text { publication bias, selective reporting within } \\
\text { studies). }\end{array}$ & $\begin{array}{l}\text { findings' tables. In Online Appendix 7, we integrated analysis of the quality of evidence } \\
\text { and the magnitude of effect of the interventions. For assessments of the overall quality } \\
\text { of evidence for each outcome that included pooled data, we downgraded the evidence } \\
\text { from 'high quality' by one level for serious (or by two levels for very serious) study } \\
\text { limitations (risk of bias), indirectness of evidence, inconsistency, imprecision of effect } \\
\text { estimates, or potential publication bias. }\end{array}$ & \\
\hline Additional analyses & 16 & $\begin{array}{l}\text { Describe methods of additional analyses } \\
\text { (e.g., sensitivity or subgroup analyses, } \\
\text { meta-regression), if done, indicating which } \\
\text { were pre-specified. }\end{array}$ & $\begin{array}{l}\text { We conducted subgroup analyses to explore potential differences in the prevalence of } \\
\text { mental health disorders during vs. after the outbreak. Heterogeneity was quantified by } \\
\text { the } I^{2} \text { statistic, where } I^{2}>50 \% \text { was deemed as substantial heterogeneity. }\end{array}$ & Page 7 \\
\hline \multicolumn{5}{|l|}{ RESULTS } \\
\hline Study selection & 17 & $\begin{array}{l}\text { Give numbers of studies screened, } \\
\text { assessed for eligibility, and included in the } \\
\text { review, with reasons for exclusions at each } \\
\text { stage, ideally with a flow diagram. }\end{array}$ & $\begin{array}{l}\text { The search resulted in a total of 2,174 records. After } 143 \text { duplicates were removed, } \\
2,174 \text { records remained to be screened. We excluded 2,042 records on title and } \\
\text { abstract screening. We assessed } 132 \text { articles in full-text and excluded } 74 \text { full-text } \\
\text { articles. Sixty-one published studies met the inclusion criteria for this systematic rapid } \\
\text { review. Fully information is provided in a PRISMA flow diagram. }\end{array}$ & $\begin{array}{l}\text { Page } 9 \text {, } \\
\text { and Figure } \\
\text { 1. PRISMA } \\
\text { flowchart. }\end{array}$ \\
\hline Study characteristics & 18 & $\begin{array}{l}\text { For each study, present characteristics for } \\
\text { which data were extracted (e.g., study } \\
\text { size, PICOS, follow-up period) and provide } \\
\text { the citations. }\end{array}$ & $\begin{array}{l}\text { Fully information is provided in the text "Characteristics of the studies" subsection and } \\
\text { in Table } 1 .\end{array}$ & $\begin{array}{l}\text { Page } 9 \text {, } \\
\text { Table } 1\end{array}$ \\
\hline $\begin{array}{l}\text { Risk of bias within } \\
\text { studies }\end{array}$ & 19 & $\begin{array}{l}\text { Present data on risk of bias of each study } \\
\text { and, if available, any outcome level } \\
\text { assessment (see item 12). }\end{array}$ & $\begin{array}{l}\text { In general, main risks of bias in the } 50 \text { cross-sectional studies were the lack of use of } \\
\text { reliable and valid instruments to measure mental health outcomes (high risk of bias in } \\
22 \% \text { of the studies) and selection bias (12\%). The main sources of bias across the seven } \\
\text { cohort studies were selection bias ( } 43 \%) \text { and inadequate follow-up of the cohorts } \\
(29 \%) \text {. Main sources of bias of the two uncontrolled before-after studies were bias in } \\
\text { selection of participants, and bias in outcome measurement. The case-control and the } \\
\text { systematic review identified did not present serious risks of bias. Results of the risk of } \\
\text { bias assessment are provided in Online Appendix } 3 \text {. }\end{array}$ & $\begin{array}{l}\text { Page } 10 \\
\text { and Online } \\
\text { Appendix } \\
3 .\end{array}$ \\
\hline $\begin{array}{l}\text { Results of individual } \\
\text { studies }\end{array}$ & 20 & $\begin{array}{l}\text { For all outcomes considered (benefits or } \\
\text { harms), present, for each study: (a) simple } \\
\text { summary data for each intervention group } \\
\text { (b) effect estimates and confidence }\end{array}$ & $\begin{array}{l}\text { We have presented both summarized data of each and the corresponding forest plots } \\
\text { (with effect estimates and confidence intervals). }\end{array}$ & $\begin{array}{l}\text { Page } 12 \\
\text { and Online } \\
\text { Appendix } \\
5 .\end{array}$ \\
\hline
\end{tabular}




\begin{tabular}{|c|c|c|c|c|}
\hline & & intervals, ideally with a forest plot. & & \\
\hline Synthesis of results & 21 & $\begin{array}{l}\text { Present results of each meta-analysis } \\
\text { done, including confidence intervals and } \\
\text { measures of consistency. }\end{array}$ & We have fully provided this information on the Online Appendix 5. & $\begin{array}{l}\text { Page } 12 \\
\text { and Online } \\
\text { Appendix } \\
5 .\end{array}$ \\
\hline $\begin{array}{l}\text { Risk of bias across } \\
\text { studies }\end{array}$ & 22 & $\begin{array}{l}\text { Present results of any assessment of risk } \\
\text { of bias across studies (see Item 15). }\end{array}$ & $\begin{array}{l}\text { In Online Appendix 7, we integrated analysis of the quality of evidence and the } \\
\text { magnitude of effect of the interventions. For assessments of the overall quality of } \\
\text { evidence for each outcome that included pooled data, we downgraded the evidence } \\
\text { from 'high quality' by one level for serious (or by two levels for very serious) study } \\
\text { limitations (risk of bias), indirectness of evidence, inconsistency, imprecision of effect } \\
\text { estimates, or potential publication bias. } \\
\text { Begg's and Egger's tests suggested the absence of publication bias for all the meta- } \\
\text { analyses conducted. }\end{array}$ & $\begin{array}{l}\text { Online } \\
\text { Appendix } 7\end{array}$ \\
\hline Additional analysis & 23 & $\begin{array}{l}\text { Give results of additional analyses, if done } \\
\text { (e.g., sensitivity or subgroup analyses, } \\
\text { meta-regression [see Item 16]). }\end{array}$ & N/A & N/A \\
\hline \multicolumn{5}{|l|}{ DISCUSSION } \\
\hline $\begin{array}{l}\text { Summary of } \\
\text { evidence }\end{array}$ & 24 & $\begin{array}{l}\text { Summarize the main findings including the } \\
\text { strength of evidence for each main } \\
\text { outcome; consider their relevance to key } \\
\text { groups (e.g., healthcare providers, users, } \\
\text { and policy makers). }\end{array}$ & $\begin{array}{l}\text { In this timely systematic rapid review we synthesized evidence from } 61 \text { studies } \\
\text { examining the impact on mental health of providing frontline healthcare during } \\
\text { infectious disease outbreaks. Results showed that HCWs commonly present high levels } \\
\text { of anxiety, depression, PTSD, acute disorder and burnout, both during and after the } \\
\text { outbreaks. We identified a broad number of risk factors for these conditions, including } \\
\text { sociodemographic factors such as younger age and female gender, and social factors } \\
\text { such as lack of social support, social rejection or isolation, stigmatization. Occupational } \\
\text { factors entailed working in a high risk environment (frontline staff), specific } \\
\text { occupational roles (e.g., nurse), and having lower levels of specialized training, } \\
\text { preparedness and job experience. In contrast with the high number of studies } \\
\text { examining impact on mental health, there is limited evidence regarding the impact of } \\
\text { interventions to reduce mental health problems in this particularly vulnerable } \\
\text { population, and overall its certainty is very low, mainly due to study design and serious }\end{array}$ & Page 15 \\
\hline
\end{tabular}




\begin{tabular}{|c|c|c|c|c|}
\hline & & & risk of bias. & \\
\hline Limitations & 25 & $\begin{array}{l}\text { Discuss limitations at study and outcome } \\
\text { level (e.g., risk of bias), and at review-level } \\
\text { (e.g., incomplete retrieval of identified } \\
\text { research, reporting bias). }\end{array}$ & $\begin{array}{l}\text { Despite searching on three major databases and that we manually searched references } \\
\text { of previously published systematic reviews, we did not examine gray literature; hence, } \\
\text { we cannot discard that relevant references may have been missed out. } \\
\text { We observed high heterogeneity when pooling data, which could be partially attributed } \\
\text { to the high variability across studies in terms of study population (e.g. occupational } \\
\text { role), context (e.g. magnitude of the health emergency caused by epidemic) and } \\
\text { outcome measures. In light of this, our results should be interpreted with caution. }\end{array}$ & Page 15 \\
\hline Conclusions & 26 & $\begin{array}{l}\text { Provide a general interpretation of the } \\
\text { results in the context of other evidence, } \\
\text { and implications for future research. }\end{array}$ & $\begin{array}{l}\text { Given the current COVID-19 pandemic, the need for timely high-quality synthesized } \\
\text { evidence has emerged as a priority worldwide. This rapid review found HCWs serving at } \\
\text { the frontline exhibit high prevalence of mental health problems, such as anxiety, } \\
\text { depression, PTSD, and burnout. Risk factors for these conditions have also been } \\
\text { identified. Few studies have documented the effects of intervention for improving } \\
\text { HCWs mental health during and after infectious outbreaks, and the quality of this } \\
\text { evidence is very low. Further well-conducted studies are warranted. }\end{array}$ & Page 17 \\
\hline \multicolumn{5}{|l|}{ FUNDING } \\
\hline Funding & 27 & $\begin{array}{l}\text { Describe sources of funding for the } \\
\text { systematic review and other support (e.g., } \\
\text { supply of data); role of funders for the } \\
\text { systematic review. }\end{array}$ & $\begin{array}{l}\text { No specific funding for this study. IRC is a recipient of a Miguel Servet Fellowship } \\
\text { (project number CP17/00017) funded by the Spanish Government. The funding sources } \\
\text { had no role in the design and conduct of the study; collection, management, analysis, } \\
\text { and interpretation of the data; preparation, review, or approval of the manuscript; and } \\
\text { decision to submit the manuscript for publication. }\end{array}$ & Page 18 \\
\hline
\end{tabular}

From: Moher D, Liberati A, Tetzlaff J, Altman DG, The PRISMA Group (2009). Preferred Reporting Items for

Systematic Reviews and Meta-Analyses: The PRISMA Statement. PLoS Med 6(7): e1000097.

doi:10.1371/journal.pmed1000097 